استتباط القواعد الأصوليت

من حلديث

صلاة العصر في بني قريظت

د.أسامة أحهد محهد كيل
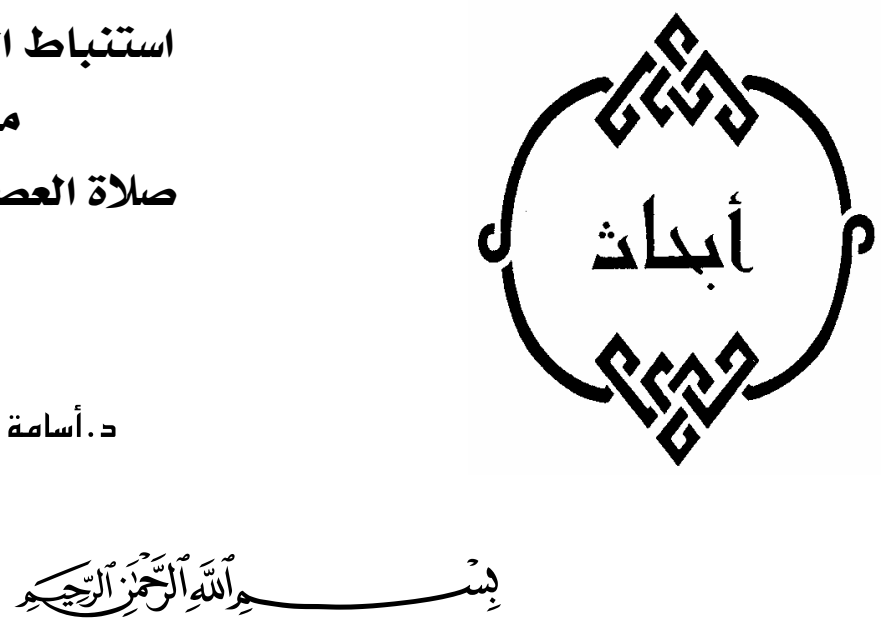

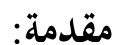

الحمد لله رب العالمين، وأشهد أن لا إله إلا الله ولي الصالحين، وأشهد أن عبده ورسوله محمدا خاتم النبيين، اللهم صل وسلم وبارك عليه وعلى آله وأصحابه وأحبابه ومتبعيه، بإحسان إلى يوم الدين، أما بعد:

فإن من يسر الشريعة الإسلامية السمحة الإذن في الاجتهاد، وترتيب الأحكام الشرعية على ما يتوصل إليه المحتهد ولو على سبيل الظن، وقد شاع بين العلماء قولهم: "لا اجتهاد مع النص" ومرادهم: إذا ثبت النص الشرعي على الحكم فلا بحال للاجتهاد تغييرا للحكم المنصوص عليه، أما إذا ورد النص الشرعي مشتملا على أمر أو هي أو أو أو

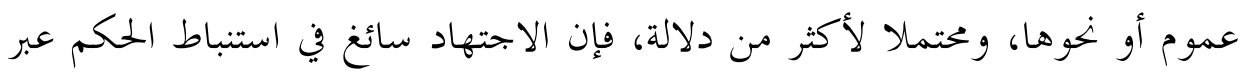
تلك الدلالات، وهذا البحث يوضح أن الاجتهاد مشروع في تأويل النص قطعي الثبوت عند المختهد، وأنه مقبول ولو كان ما أدى إليه الاجتهاد صرفا للنص عن

(") كلية الشريعة وأصول الدين بجامعة الملك خالد - أها- المملكة العربية السعودية. 
ظاهره، وحملا له على معنى بعيد انقدح للمجتهل رجحانه، بعد تمحيص الأدلة والدلالات والقواعد، متئ كان البحتهد متضلعا من العلم الشرعي، مستوفيا لشروط الاجتهاد، ورعا تقيا لم يقترف هوى ولا تشهيا يبعده عن الجادة المستقيمة، كما أنه

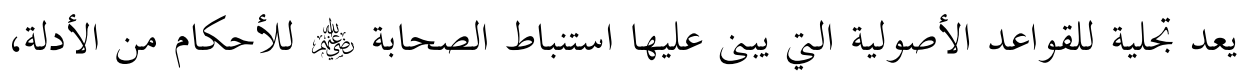
تلك القواعد التي كانت معلومة في الصدور، و إن لم تكن مدونة في السطور.

\section{أهمية الموضوع: (أهوع}

تنبع أهمية موضوع البحث من كونه يعالج مشكلة مزمنة ومتجددة بين أفاضل الظاهرية المتمسكين بحرفية النص من ناحية، وبين جهابذة أصحاب التأويل الذين لا يألون جهدا في استقراء المعاني، والتعرف على مدى تأثيرها في الأحكام، وتوسعة باب الاجتهاد بناء على النظر في الدلالات و المصالح من ناحية أخرى، وهذه القضية لا يكاد يخلو زمن ولا مكان من الحاجة - بل الضرورة - إلى الانصياع للحكم الشرعي فيها بعدم تعنيف المخالف، ووجوب الاحترام والتقدير المتبادل بين المختلفين من المحتهدين، وبتحويز عمل كل من البحتهدين في خاصة نفسه بما أداه إليه اجتهاده، سواء كان ظاهريا أم متأولا مع الاعتر اف بحقوق الآخرين والتزام الجميع .ما جرى عليه القضاء، أو سنت على أساسه الأنظمة واللو ائح والقوانين؛ رفعا للخحاف متى كان الحكم اجتهاديا،

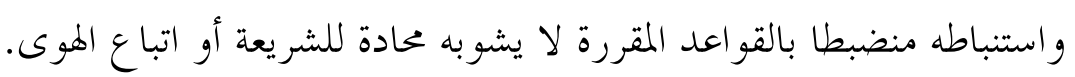

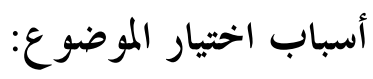
إضافة إلى ما سبق في أهمية الموضوع فإن ثمة أسبابا لاختياره جعلته جديرا بتوفري عليه، و بذل غاية الوسع في تفصيله و تأطيره، وعرضه هذه الصورة، وأهمها: 1 - رغبتي الشديدة في تلبية رغبة بنجباء طلاب العلم الشرعي في التعرف على مكانة قواعد علم أصول الفقه في زمن الوحي ومدى استحضارها لدى علماء الصحابة الكرام. 
Y - إعلاء القواعد السامية لآداب الاختلاف في الإسلام، وخصوصا عند قناعة كل ذي رأي برأيه. r - تيسير تطبيق قواعد أصول الفقه على النصوص الشرعية، ورد الرأيين الفقهيين في المسألة الواحدة إلى المنــزـزع الأصولي لكل منهما.

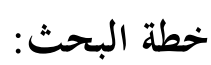

يتكون البحث من مقدمة، وتمهيد، ومبحثين، و خاتمة، وبياها كالتالي: المقدمة، وتشمل أهمية الموضوع وأسباب اختياره وخطته ومنهجه. تمهيد: نص الحديث ودلالته على فقه الصحابة ودقة استباطهم. المبحث الأول: الأدلة الإجمالية وقضايا الحكم الشرعي والاجتهاد و التقليد عند الأصوليين وعلاقتها بالحديث، ويتضمن ثلاثة مطالب:

المطلب الأول: الأدلة الإجمالية عند الأصوليين وعلاقتها بالحديث. المطلب الثاني: تقسيمات الحكم الشرعي عند الأصوليين وعلاقتها بالحديث. المطلب الثالث: قضايا الاجتهاد و التقليد عند الأصوليين وعلاقتها بالحديث. المبحث الثاني: قواعد الاستنباط من النصوص والترجيح بينها عند الأصوليين وعلاقتها بالحديث، ويتضمن مطلبين:

المطلب الأول: قواعد الاستنباط من النصوص عند الأصوليين وعلاقتها بالحديث. المطلب الثاني: التعارض و التوفيق والترجيح عند الأصوليين وعلاقتها بالحديث. الخايتمة: وتضمن خلاصة البحث و نتائجه.

\section{منهج البحث:}

يتمثل منهج البحث، وخطو اته في الآتي:

ا - يعتمد البحث المنهج الاستقرائي في تتبع مدلولات الرواية من المعاني، ثم المنهج 
الوصفي التحليلي توصلا إلى تحديد ما يتعلق بأصول الفقه من هذه الدلالات،

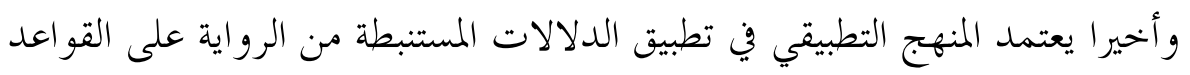
المسطورة في علم أصول الفقه، وقد يتصرف الباحث في لفظ القاعدة مع المحافظة على جوهر معناها؛ لتظهر العلاقة بين التنظير والتطبيق. r- يشترط في القاعدة الأصولية التي تورد بالبحث أن تكون معلومة عند علماء الأصول، ولا يشترط الاتفاق عليها، وإيرادها ليس دليلا على ترجيح الباحث ما دلت عليه. r- استنباط القاعدة في البحث يقصد به: إمكان دلالة ما ورد في الحديث عليها بوجه من الوجوه، وإن لم يكن متفقا عليه، أو سبق لأهل العلم استنباطه، ويكفي التوجيه وإن لم يكن مسلما عند الباحث. ع - تحنبت الاستطراد بذكر التعريفات الاصطلاحية، و التراجم، و كثير من الإضافات التي تزدان ها البحوث العلمية المطولة، وذلك مراعاة لوقت المتخصصين أولي النهى الذين قد يشرف البحث باطلاعهم عليه. ه- اكتفيت في العناوين بلفظ (الحديث) عوضا عن عبارة (حديث صلاة العصر في بين قريظة) وحيث قلت في ثنايا البحث (الطائفة الأولى) فالمراد: الطائفة التي أوقعت صلاة العصر أولا حيث صلت في الطريق، ومن تثم فقولي (الطائفة الأخرى) أعني به: الطائفة التي أخرت صلاة العصر عن وقتها و لم تصلها إلا في بني قريظة إيمانا وامتثالا للنص النبوي. 


\section{تمهيل \\ نص الحلديث ودلالته على فقه الصحابت ودقت استنباطهه}

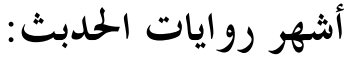

هذا الحديث مما اتفق عليه الشيخان، وإسناده من الأسانيد العالية بصفة عامة،

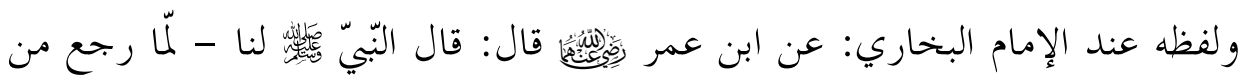

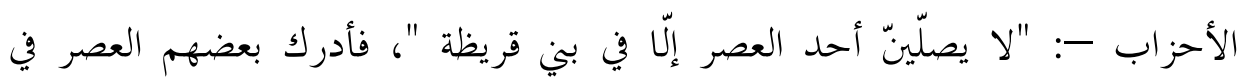

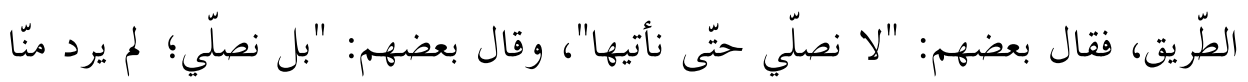

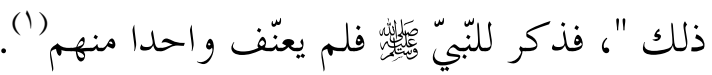

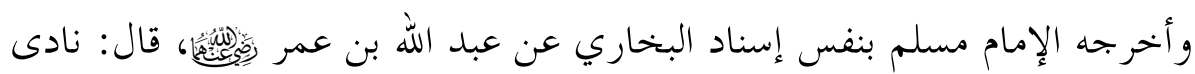

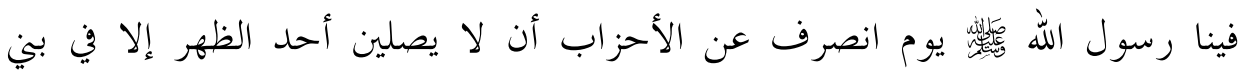
قريظة، فتخوف ناس فوت الوقت، فصلوا دون بني قريظة، وقال آخرون: "لا نصلي

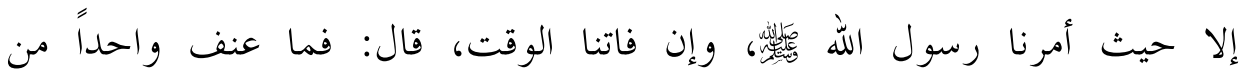

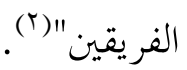
و لم تختلف الروايتان إلا في تعييين الصلاة المقصودة، حيث ورد في صحيح مسلم:

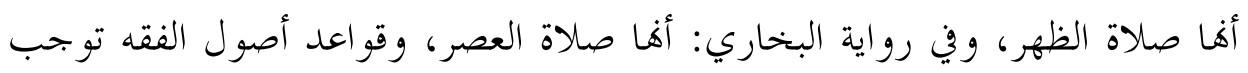

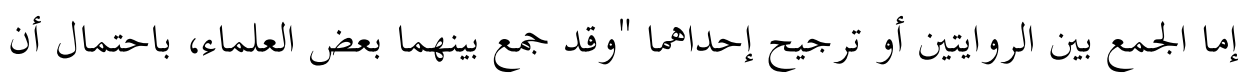

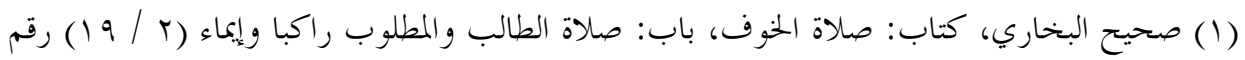

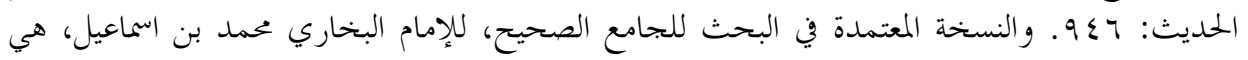

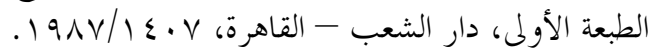

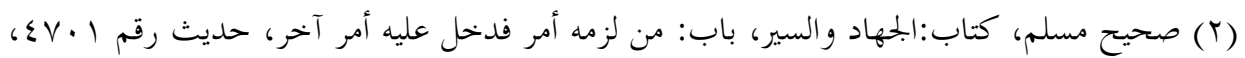

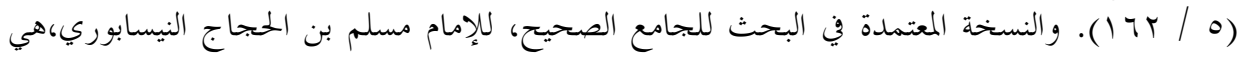
طبعة دار الجيل - بيروت. والندة المعند. 
يكون بعض الصحابة قد صلى الظهر قبل الأمر، وبعضهم لم يصلها، فقيل لمن لم يصلها: لا يصلين أحد الظهر، ولمن صلاها: لا يصلين أحد العصر، وجمع بعضهم باحتمال: أن تكون طائفة منهم راحت بعد طائفة، فقيل للأولى: الظهر، وقيل للطائفة

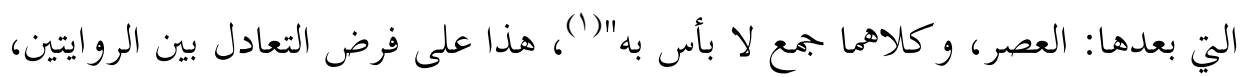
لكن درج المحدثون على ترجيح كوها صلاة العصر، حيث لا يستشهدون بالحديث ولا يشيرون إليه إلا بلفظ "صلاة العصر"؛ بناء على استقراء الروايات وتنوع

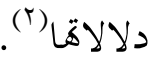

أما استنباط القواعد الأصولية - وهو بجال بحثنا - فلا يختلف ولا يتأثر بالفرق بين الكلمتين، فكيفية الاستفادة من اللفظين واحدة، وسيجري البحث على أها صلاة العصر؛ اعتمادا على ترجيح أهل الاختصاص، وهو المتبادر؛ لما ورد في بعض الروايات أن اختلاف الطائفتين كان قبيل غروب الشمس، في حين لم تذكر أية رواية شيئ يشير لانتهاء وقت الظهر، ولا لجمعها مع العصر. اعتماد البحث على رواية الصحيحين: أنعمت النظر في كل ما وقفت عليه من المعاني في رواية الصحيحين، واستقرأت كل ما أمكنين استنباطه منها من قو اعد وفو ائد، و اكتفيت بذلك؛ إذ و جدةا مع صحتها تغني عما سواها، فلم أقف في سائر الروايات على مزيد استنباط للقواعد، اللهم إلا في موضع و احد، حيث اشتملت رواية: "من كان سامعا مطيعا فلا يصلّينّ العصر إلاَّ في بني قريظة"، على معنى يمكن توظيفه في

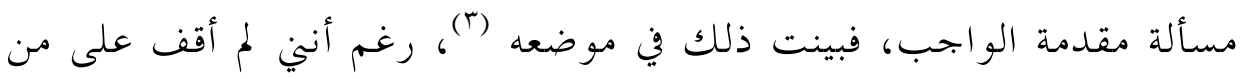

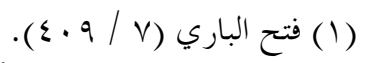

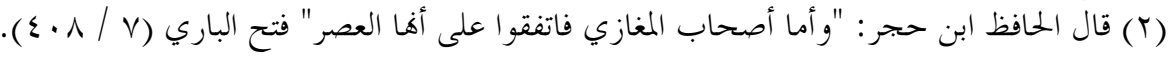

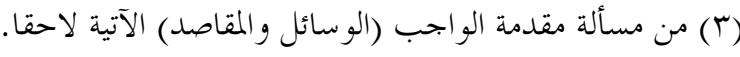




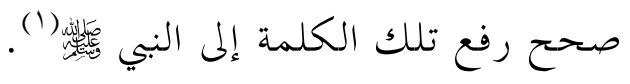
ولأصوليين عناية بأحو ال الإسناد؛ لأها إحدى مقدمات الاستدلال بالنص، حيث يتوقف على صحة الإسناد قبول الرواية، كما يتوقف الترجيح في بعض قواعده على

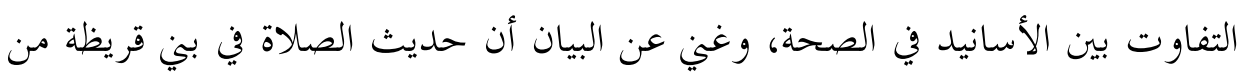
الصحيح المقبول، ويكفي أنه رواه أكثر العلماء تثبتا في الرواية، شيخا المحدثين البخاري ومسلم، ومما يحسن التنبيه عليه: أن القاعدة عند الأصوليين تقديم صيغة (حدثنا وحدثني) على صيغة (قال)؛ لقوها، فهي تدل على المشافهة بطريق النص، لكن لا بحال

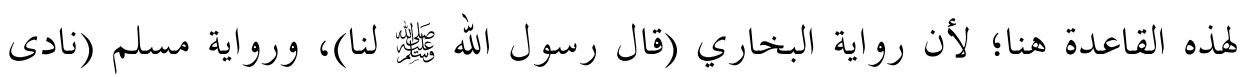
فينا رسول الله

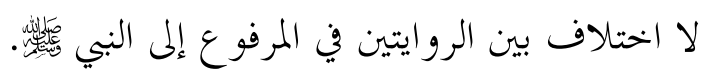

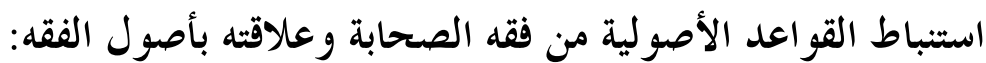

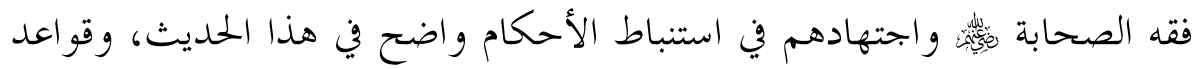
أصول الفقه لم تكن بمنأى عن فكرهم، بل كانوا يتقنوها ويطبقوها دون الحاجة إليها مدونة ومحفوظة، كما هو شأننا، وفرق ما بينا وبينهم في هذا المجال كالفرق في تطبيق القواعد النحوية، حيث نحتاج إلى الدراسة والتدرب والتطبيق، في حين بند الثمرة المرجوة لنا متحققة عندهم، دون حاجة إلى ذلك وكذلك علم التجويد والعروض وغيرها. وقول الطائفة الأولى: "بل نصلي! لم يرد منا ذلك!" تصريح ممقتضى النظر في

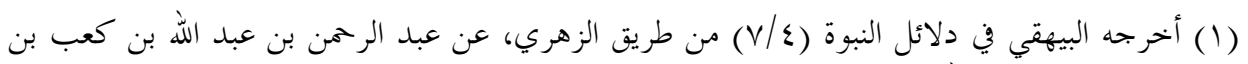

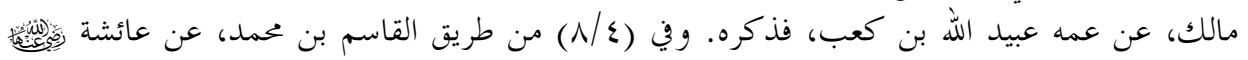

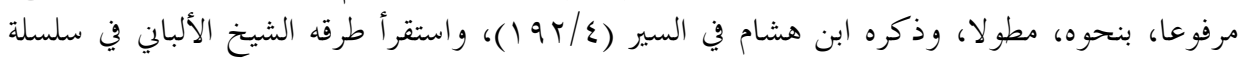

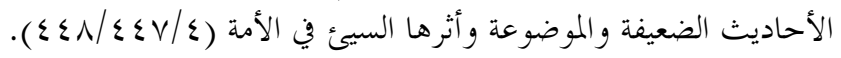


دلالات النص، ودلالات النصوص الأخرى، التي ذخرت هـا المؤلفات الأصولية. واستنباط القواعد الأصولية من الاجتهادات الفقهية للأئمة المجتهدين إحدى طريقتي التأليف المشهورتين عند الأصوليين، وقد عرفت باسم طريقة الحنفية، ومدرسة الحنفية، وطريقة الفقهاء؛ لأن التحرير و الصياغة والتدوين للمذهب الفقهي فيها أسبق من تقعيد القاعدة وصياغتها، وإن كانت القاعدة من حيث و جودها الذهني عند البحتهد ملازمة للدليل وقت الاستنباط، فهي أسبق من الفقه وجودا، وإن تأخرت عنه تدوينا. وثم بعض المسائل الأصولية الوارة بالبحث لم تستنبط من فقه الصحابة، بل استنبطت مباشرة من النص النبوي، وهو تخريج للأصول من الأدلة، ويعرف هذا اصطلاحا بطريقة الجمهور، أو المتكلمين، أو مدرسة المتكلمين، ومثالها قاعدة: "ابحتهد مأجور وإن أخطأ." 


\section{المبحث الأول}

الأدلن الإجماليت وقضايا الحكه الشرعي والاجتهاد والتقليد عند الأصوليين وعلاقتها بالحلديث

\section{المطلب الأول: الأدلة الإجمالية عند الأصوليين وعلاقتها بالحديث المسألة الأولى: الأدلة الإجمالية عند الأصوليين}

عرف علم أصول الفقه بأنه: "معرفة أدلة الفقه الإجمالية، وكيفية الاستفادة منها،

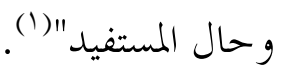
ومصطلح الأدلة الإجمالية التي يختص بدراستها علم أصول الفقه يجيء مقابلةً لمصطلح الأدلة التفصيلية التي يعنى هـا علم الفقه، فعناية الفقيه بالآية القرآنية، وبالحديث النبوي، وأما عناية الأصولي فبالقرآن الكريم إجمالا وبالسنة النبوية إجمال، فيبحث في بئين قو اعد الاستدلال والترجيح، وما يتوقف عليه الاستنباط من نصوص الكتاب و السنة.

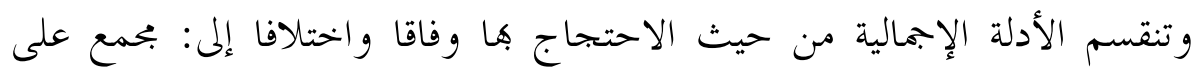
الاحتجاج بها، ومتفق عليها، ومختلف فيها.

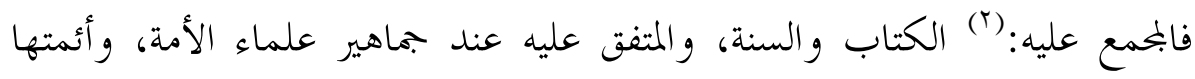
المعتبرين سلفا وخلفا هو: الإجماع والقياس. واختلف الأئمة المعتبرون في الاحتجاج بسائر الأدلة الإجمالية واختلفوا كذلك في شروطها، و بعض صورها، وضو ابطها، وبحالاها، ومن ذلك: إجماع الشيخين أبي بكر وعمر، وإجماع أهل المدينة، والاستحسان، وشرع من قبلنا، وقول الصحابي، و المصالح

(1) عبر العلامة البيضاوي بلفظ (دلائل الفقه)، وله وجهته - انظر : المنهاج بتحقيق الشيخ محيي الدين عبد الحميد ص ع ع. (T) في عصر الصحابة وسائر العصور، و إنكار الاحتجاج بالسنة مكابرة .ما يتيقن المكابر بطلانه. 
المرسلة، والاستقراء الناقص، والاستصحاب، والأخذ بأقل ما قيل، وسد الذرائع..

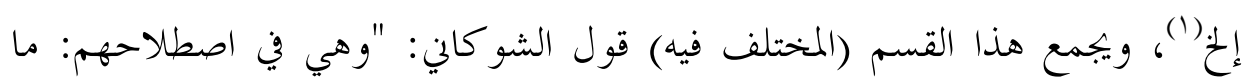
ليس بنص، و لا إجماع و لا قياس (「)". و تنقسم من حيث كون الدليل نصا شرعيا أو مستنبطا من النصوص الشرعية إلى: نصية وغير نصية، فالنصية: الكتاب و السنة، وسائر الأدلة الإجمالية ليست بنصية. وتنقسم الأدلة بعد عصر الصحابة إلى: نقلية، وعقلية، و كلاهما يعضد الآخر في

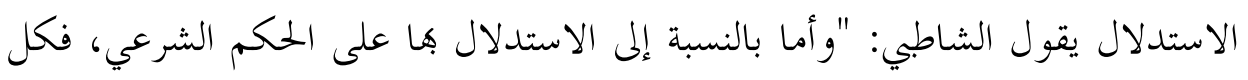

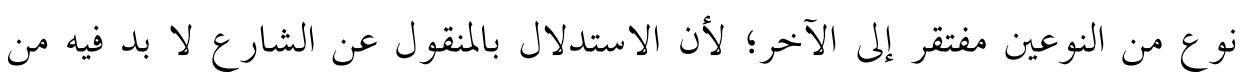

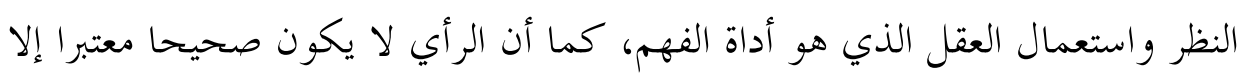
إذا استند إلى النقل؛ لأن العقل البحرد لا دخل له في تشريع الأحكام"(").

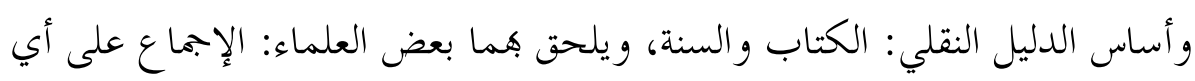
و جه قيل به، ومذهب الصحابي، وشرع من قبلنا(ع)، والدليل العقلي يطلق بالأصالة على القياس، والاستدلال، ويلحق به الاستحسان، والمصالح المرسلة، كما قال

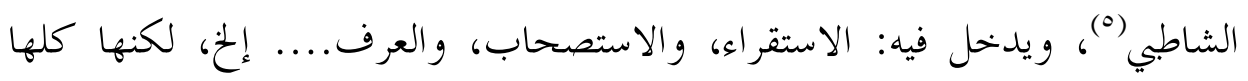
راجعة إلى "الاستدلال" .معناه الأعم (؟).

(1) انظر: دلالة الكتاب والسنة على الأحكام ، د. عبد الله يوسف مصطفى عز ام، رسالة دكتوراه، دار

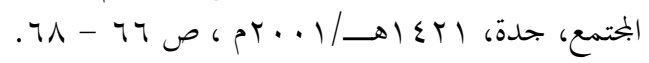

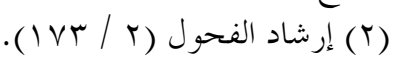
(r) الموافقات ابراهيم بن موسى الشاد (Y) الشاطبي، تحقيق: أبو عبيدة مشهور حسن، دار ابن عفان، الطبعة الأولى،

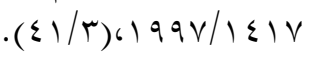

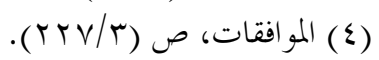

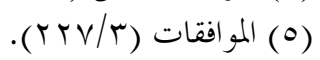

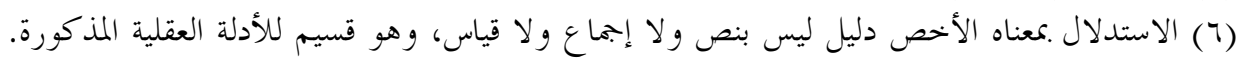

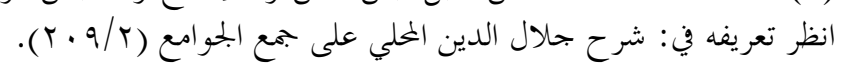
$-\varepsilon Y$. 
المسألة الثانية: الاستدلال بالسنة المنشئة للحكم في الحديث أقسام السنة المبينة للحكم:

للسنة في بيان الأحكام من حيث وجود نص قرآني في موضوع الحكم إلى ثلاثة أقسام: فالأول: السنة المؤكدة، ويثبت هـا حكم نص القرآن عليه، فيكون الحكم عليه دليلان، و القسم الثاني: السنة المبينة، وهي التي توضح البحمل من الدليل القرآي، أو تبين

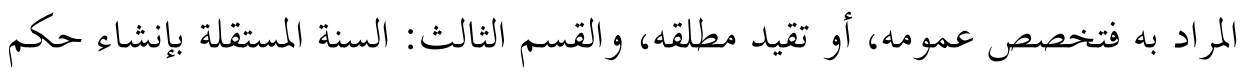

سكت عنه القرآن، يقول الإمام الشافعي - رحمه الله - في الرسالة (1):

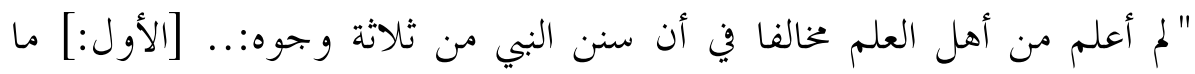
أنــزل الله فيه نص كتاب فبين رسول الله مثل ما نص الكتاب، [و الثاني:] ما أنــــل

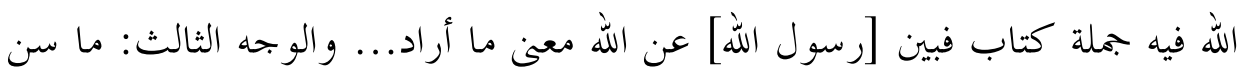
رسول الله فيما ليس فيه نص كتاب".

وفي الرسالة - أيضا -: "قال الشافعي وما سن رسول الله فيما ليس لله فيه حكم فيه

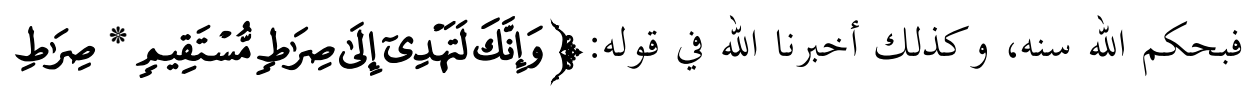

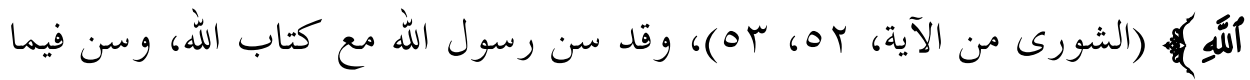
ليس فيه بعينه نص كتاب، و كل ما سن فقد ألزمنا الله اتباعه، و جعل في اتباعه طاعته،

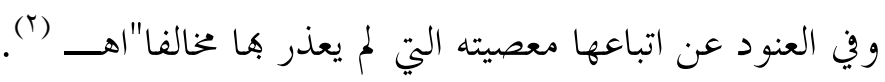
دلالة الحديث على احتجاج الصحابة بالسنة المستقلة بالتشريع: وهذا الحمديث من القسم الثالث، وهو السنة المنشئة للحكم؛ لأن وجوب إيقاع صلاة العصر ذلك اليوم في بني قريظة حكم سكت عنه القرآن.

(1) الرسالة، الإمام محمد بن إدريس الشافعي، المحق: أحمد محمد شاكر، دار الكتب العلمية، ص او - 
و لم يتردد أحد من الصحابة الكرام في الامتثال لهذه السنة النبوية؛ لما وقر في قلوهمم من حجية السنة، ووجوب طاعة رسول الله ئس المحكمة قطعية الثبوت قطعية الدلالة على ذلك.

\section{المسألة الثالثة: الاستدلال بالسنة القولية قطعية الثبوت ظنية الدلالة في الحديث}

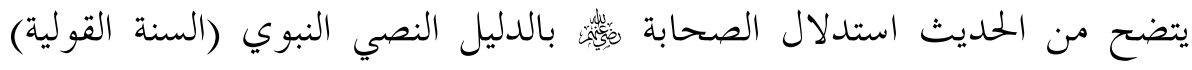
وذلك في عمل الصحابة بالنص الصادر عن النبي لَّلِّ، ونصه في صحيح البخاري عَنْ

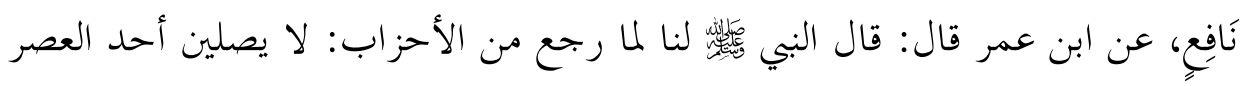
إلا في بين قريظة (1) وهذا النص قطعي الثبوت عند المستدل (وهم الصحابة)، أما عندنا فقطعية الثبوت

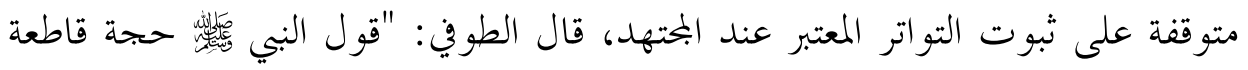

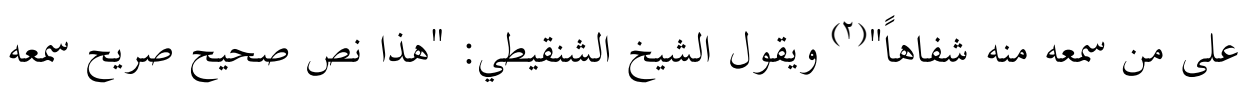

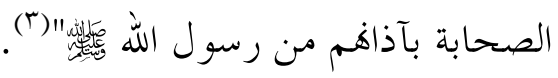

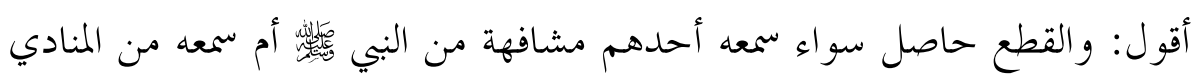
الذي يقطع السامع بأنه مبلغ عن البي فئل وبعض الصحابة الكرام ومن جاء بعدهم من أهل العلم رأى هذا النص قطعي

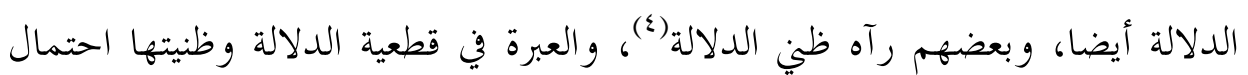
(1) صحيح البخاري، كتاب: صلاة الخوف، باب: صلاة الطالب والمطلوب راكبا وإيماء حديث رقم (1)

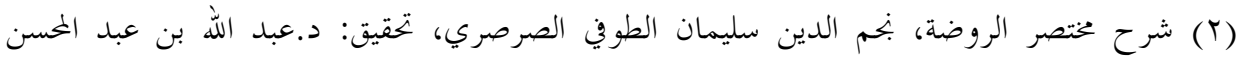

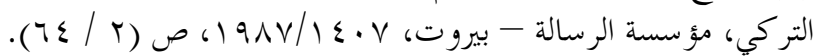

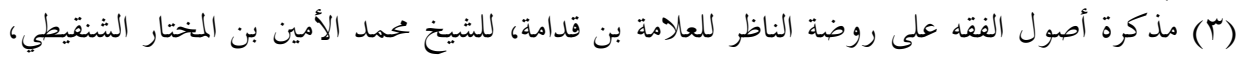
(ع) بدليل تأو يلهم له وصرفهم إياه عن ظاهره. 
الدليل لأكثر من مدلول، فمتى سلم المستدل بثبوت الاحتمال فقد سلم بظنية الدليل،

$$
\text { وإن كان الاحتمال مرجوحا. }
$$

\section{المسألة الرابعة: الاستدلال بالسنة الثقريرية في الحديث}

بينما يدخل علماء الحديث في تعريف السنة تفصيلات تجعلها واسعة المدلول لتشمل

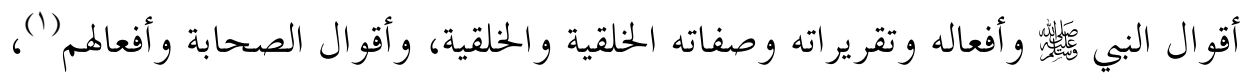

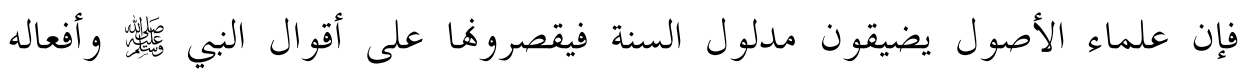
وتقريراته، وبعضهم يكتفي بالأقوال والأفعال بناء على أن التقرير نوع من الفعل؛ لأنه كف عن الإنكار، والكف فعل (r). والمقصود بالسنة التقريرية: ما صدر عن بعض الصحابة - رضي الله عنهم - من فئ

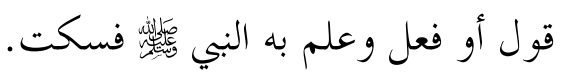

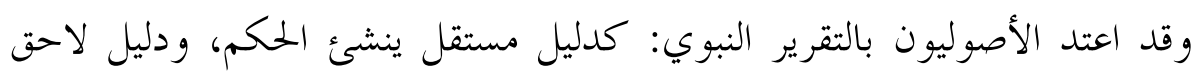
يبين البحمل، ويخصص العموم و يقيد المطلق.

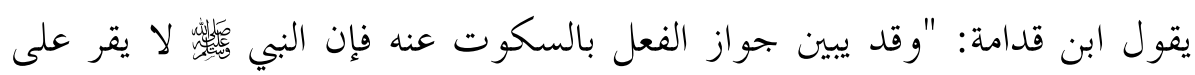
الخطأ فكل مفيد من الشارع بيان" (r).

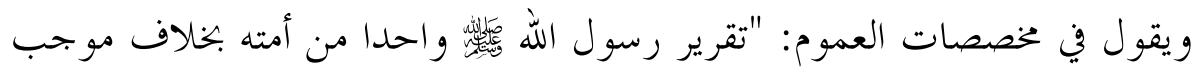

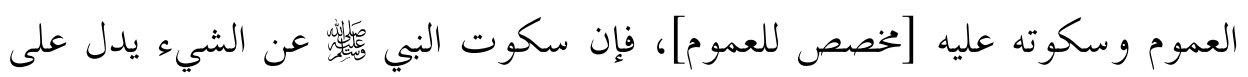

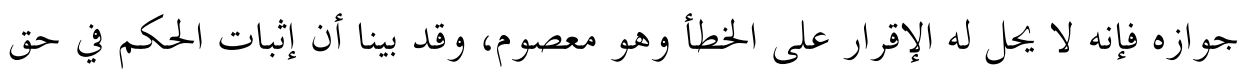

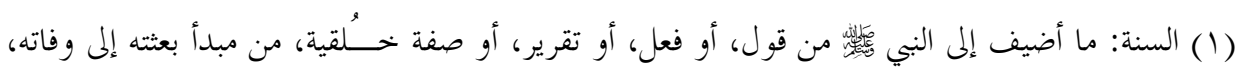

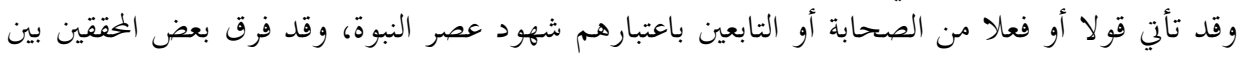

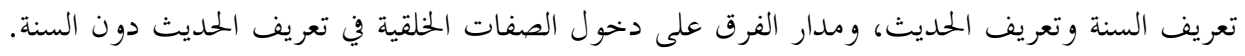

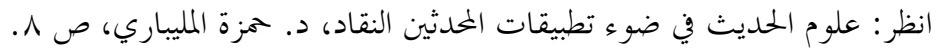

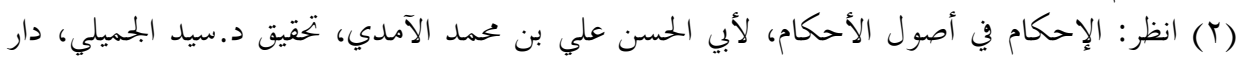

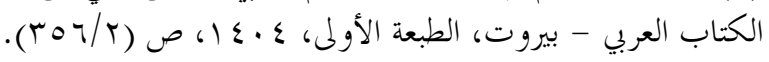

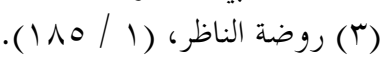




$$
\text { واحد يعم الجميع (1) }
$$

وسكوت البي

$$
\text { قريظة) تقرير لفعل الفريقين (r) }
$$

ومن ثم فإن لهذا التقرير أثره في القواعد الأصولية المستنبطة من اجتهاد الصحابة

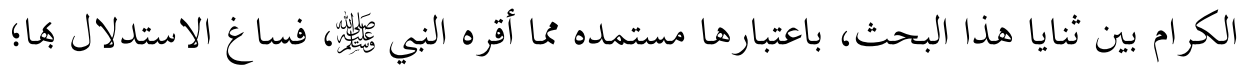
لما أسبغه عليها التقرير النبوي من الحجية. المسألة الخامسة: الأقيسة المستنبطة من الحديث

للقياس مدخل في الاستنباط من هذا الحديث، وذلك عبر فروع فقهية بعضها صحيح ومتعلق باجتهاد الصحابة، وبعضها قيل به لكن فيه نظر (r)، وسأتناول ذلك فرك

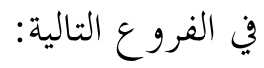
الفرع الأول: قياس جميع الثواغل عن النفير على الصلاة المنصوص على حكمها. لا شك أنه تبادر لدى الصحابة الكرام تحريم الانشغال عن الخروج للجهاد بأي شاغل، ويمكن إجراء قياس صحيح مستوف أركانه وشرائطه، فنقول: الانشغال بصلاة العصر في غير بني قريظة حرام بظاهر النص، وعلثه: خوف فوت عنصر المفاجأة، فكل ما يعطل عن الخروج حرام أيضا قياسا على الانشغال بصلاة العصر؛ لوجود نفس العلة فيه.

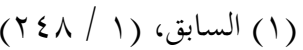

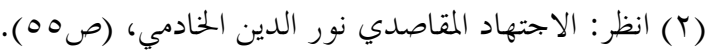

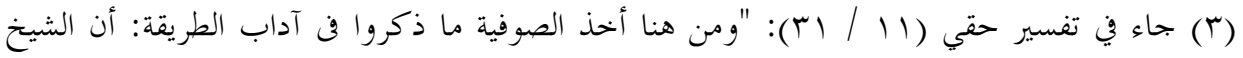

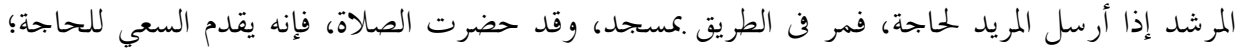

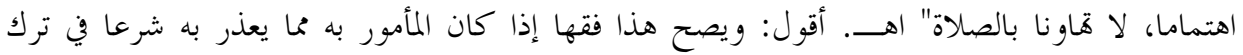

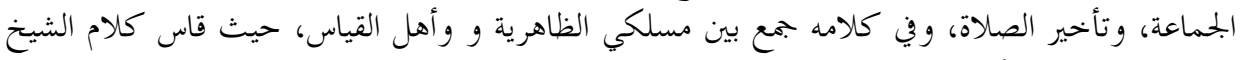

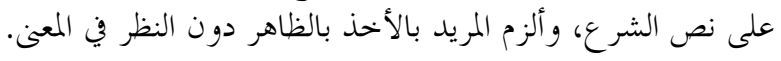




\section{الفرع الثالي: تخصيص العموم بالقياس.}

ذكر بعض العلماء أن الطائفة الأولى أعملت القياس، فخصصت بن به عموم النص، يقول ابن تيمية: "فالأوّلون تمسّكوا بعموم الخطاب، فجعلوا صورة الفوات داخلة في العموم، والآخرون كان معهم من الدّليل ما يوجب خروج هذه الصّورة عن العموم؟ فإنّ المقصود المبادرة إلى الذين حاصرهم البي صلى الله عليه وسلم. وهي مسألة اختلف فيها الفقهاء اختلافا مشهورا: هل يخصّ العموم بالقياس؟"(1)، وقد تبعه على إنى ذلك بعض المحققين (r).

أقول: ولعله يقصد بتخصيص العموم استثناء صورة الفوات، فيرخص في الانتقال إلى حكم آخر وهو الصلاة في الطريق لمن خاف فوات وقت الصلاة؛ قياسا على نظير يتفق طرفا الاستدلال في المسألة على حكمه، مثل: الترخص في الانتقال إلى التيمم؛ لضيق الوقت، عوضا عن الغسل أو الوضوء. الفرع الثالث: قياس المفرب وما بعدها على صلاة العصر. ظهر لي أن للقياس تأثيرا افتراضيا، حيث لم ينص عليه في الحديث، و لم يشر الصحابة الكرام إليه، وليس في تخصيص العموم، بل ربما قلت إنه في أحد أضداده، وهو تعميم الخاص، فهل يلحق المغرب وما بعده من الصلوات بصلاة عصر ذلك اليوم، فلا تصلى إلا في بني قريظة؟ هذا بجال القياس، ويجري فيه الاجتهاد، فيمكن القول بأن المغرب لا تصلى إلا في بني قريظة بطريق قياس الأولى. ويمكن أن يقال: إن صلاة العصر خارجة عن قاعدة القياس، وما خرج عن قاعدة القياس فغيره عليه لا

(1) رفع الملام عن الأئمة الأعلام، ابن تيمية، تحقيق / عبد الله الأنصاري، المكتبة العصرية - بيروت، ص

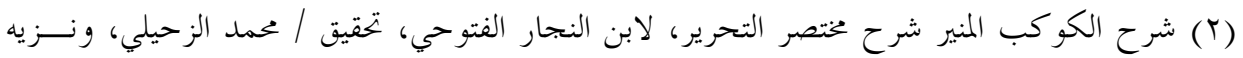

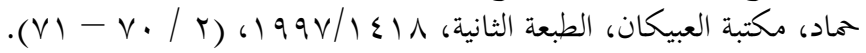




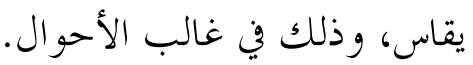
ولم أقف في روايات الحديث على لفظ دال على ثبوت الحكم في تلك الصلوات بأي وجه من وجوه الدلالات، فبقي الاجتهاد. وقد أشار إلى هذا المعنى العلامة ابن كثير حيث عزا إلى الى طائفة جواز الترخص

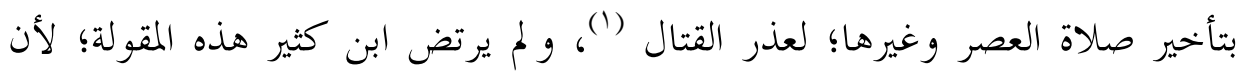
أصحاب هذا القول محوجون بما لا يكصى من الأدلة. ومهما كان المستند الاجتهادي فلن يمكن إعمال القياس تحقيقا، ولكن افتراضا،

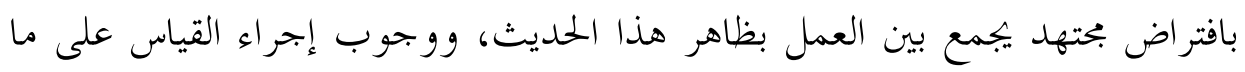
أثبته من حكم.

والعلامة ابن حزم لم يتعرض لهذا الحكم بالتنصيص عليه، لكن يستفاد من كلامه:

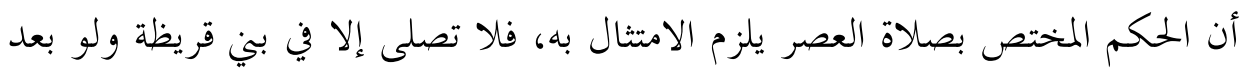

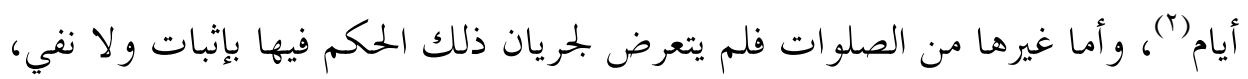

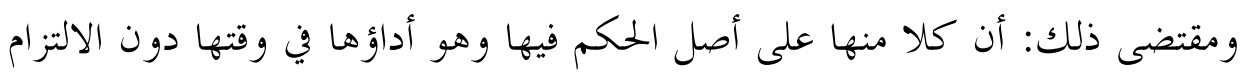

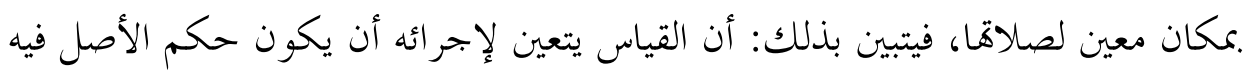

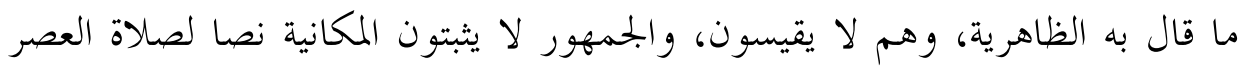

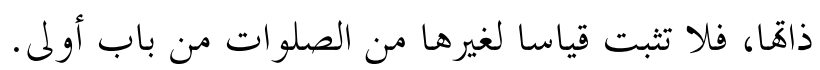

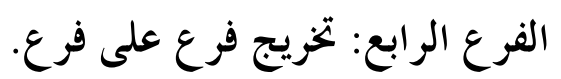

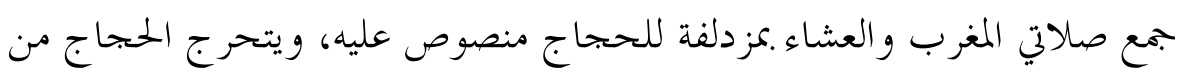

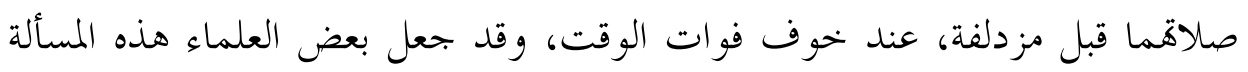

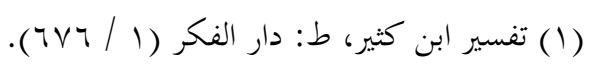

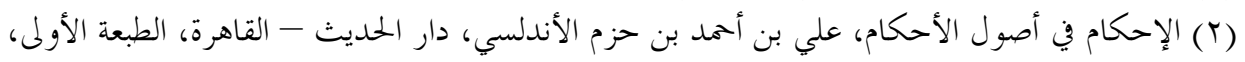
( 
نظيرا لهذا الفرع، قال ابن بطال في شرح البخاري: "ألا ترى أن من صلاهما بعد

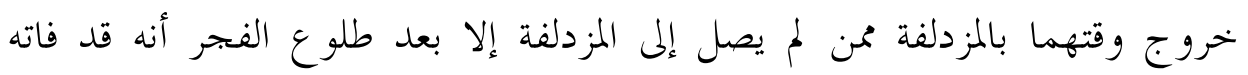

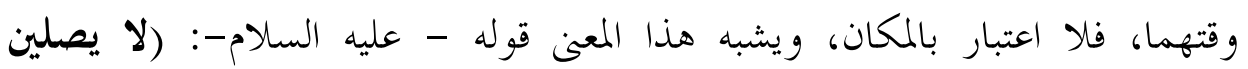
أحدكم العصر إلا فى بنى قريظة).... "(1). أقول: والقياس في هذا الفرع دليل استئناسي يشهد للحكمي؛ لأن حكم الصلاة

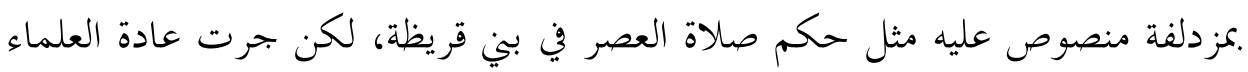

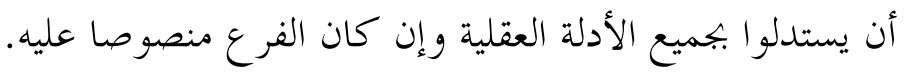

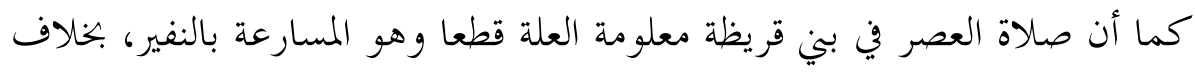

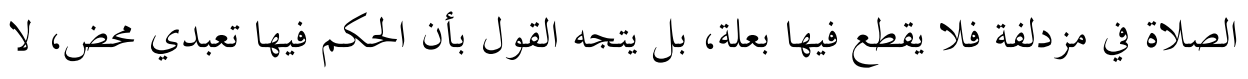
يضير المكلفين جهل علته، أو خفاء حكمته.

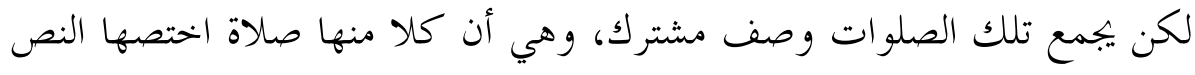

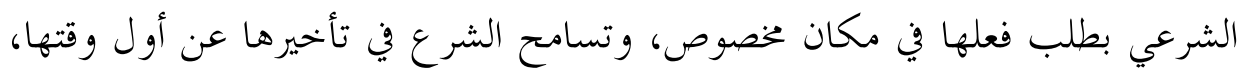
فتكون المسألة مبنية على مدى جواز التعليل بالحكم الشرعي.

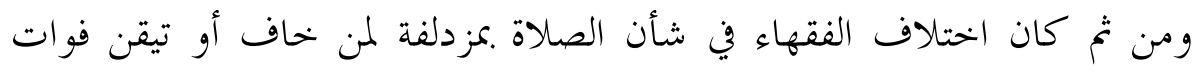

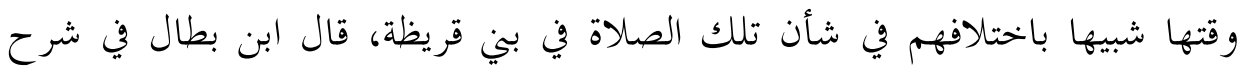

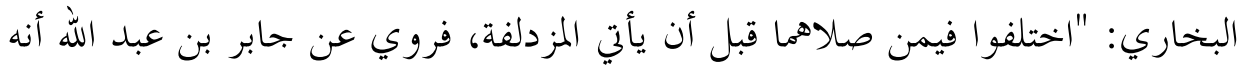

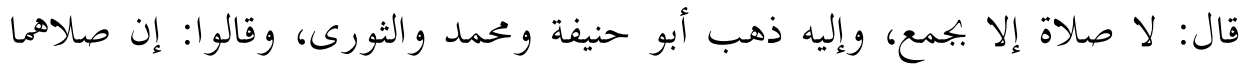

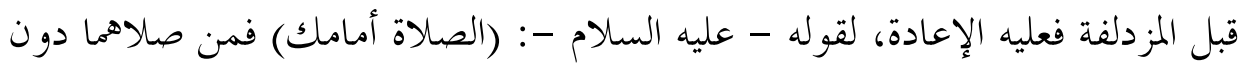
المزدلفة فقد صلاهما في غير وقتهما، ومن صلى صلاة فن غير وقتها فعليه إعادها بعد

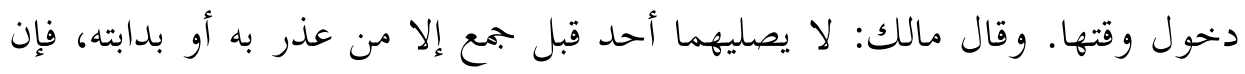

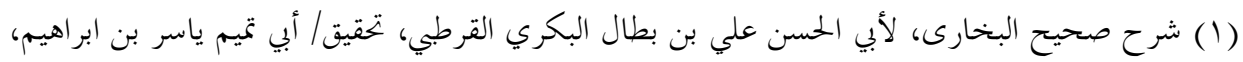

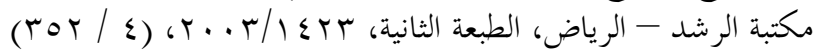


صلاهما بعذر لم ميجمع بينهما حتى يغيب الشفق. وفيها قول ثالث: إن صلاهما قبل جمع

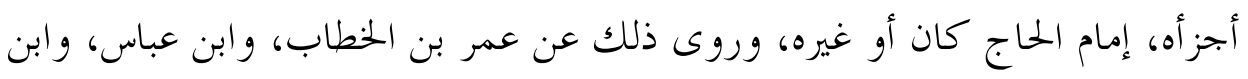
الزبير، وعن عطاء، وعروة، والقاسم، وبه قال الأوزاعي، وأبو يوسف، والشافعي،

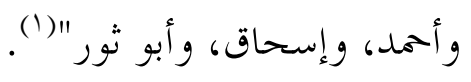

المسألة السادسة: رعاية المصالح والمقاصد في الحديث

يقصد برعاية المصلحة: التوصل إلى استنباط حكم شرعي يكقق تحصيل المنفعة أو

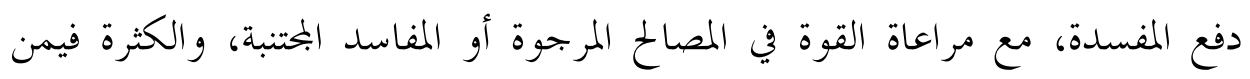
يتأثرون بالحلكم، يقول العلامة العز بن عبد السلام: "الشريعة كلها مصالح: إما أن تدرأ مفاسد أو تحلب مصالح" (؟). ولا شك أن الطائفة الأولى ثبت لديها بالاجتهاد أن الحكم في قضيتهم مبني على المصلحة، والمصلحة المرعية هنا هي حفظ الدين، ويتوصل إليها بالمسارعة لتحقيق عنصر المباغتة، فلم تقتصر على النظر في دلالة اللفظ الظاهرة، "وإنما التجأت إلى تأويله بطريق الالتفات إلى المقصد والمعنى والغرض من الأمر بأداء صلاة العصر في بني قريظة، و الذي يتمثل في الحث على الإسراع وترك التثاقل والتباطؤ في السير"(ب).

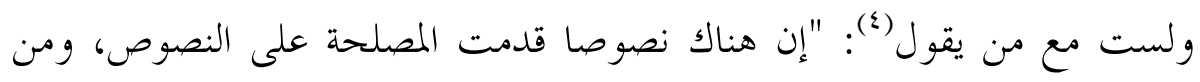

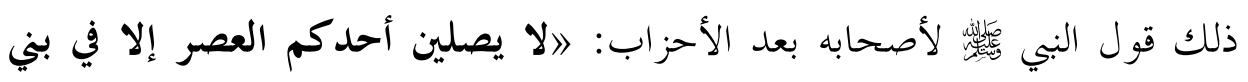
قريظة)، فصلى بعضهم قبلها، فقررهم على ذلك؛ إذ فيه تقديم المصلحة (مصلحة إدر اك الوقت) على النص"

(1) (1) شرح صحيح البخارى لابن بطال (ع / ( (1) (1) ).

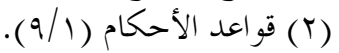

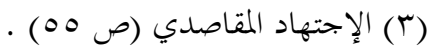

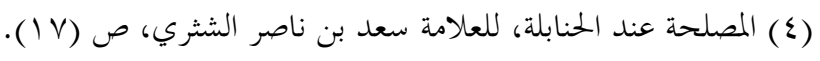


فإن المتبادر من هذه العبارة اعتبار المصلحة وإهمال النص، و الظاهر من فعل

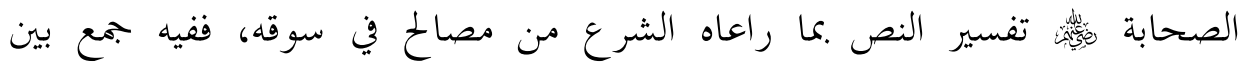
مدلو لات النص بالعمل بالظاهر المتبادر منه عند الإمكان، وتخصيصه بالمصلحة عند الضرورة، ولا يسمى ذلك تقديما للمصلحة على النص.

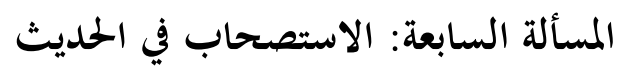
ذكر بعض أهل العلم أن الطائفة الأولى استدلت بالاستصحاب، فقال: "دابل "دليل الاستصحاب وقع في زمانه - عليه الصلاة والسلام - في قصة بني قريظة.... فمنهم من قال باستصحاب الأصل فقال: إن الأصل أن نصلي العصر في وقتها، ورسول الله ل.

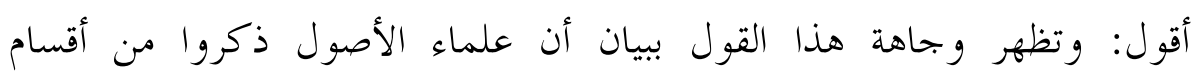
الاستصحاب "استصحاب دليل الشرع: مثل استصحاب العموم إلى أن يرد تخصيص، واستصحاب النص إلى أن يرد النسخ، واستصحاب حكم دل الشرع على ثبوته

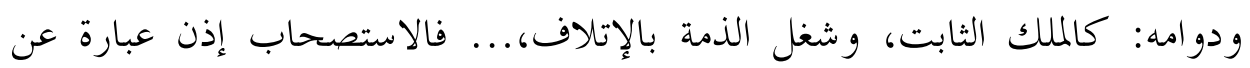

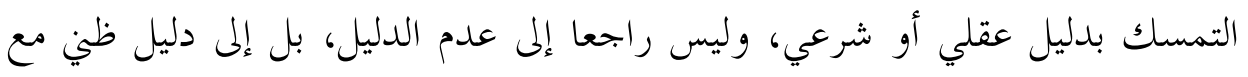
انتفاء المغير أو العلم به"(؟).

المطلب الثاني: تقسيمات الحكم الشرعي عند الأصوليين وعلاقتها بالحديث المسألة الأولى: تقسيمات الحكم الشرعي عند الأصوليين

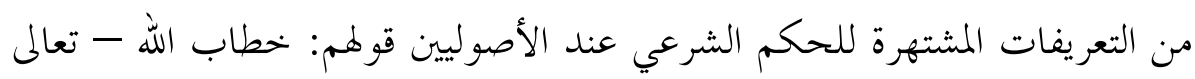

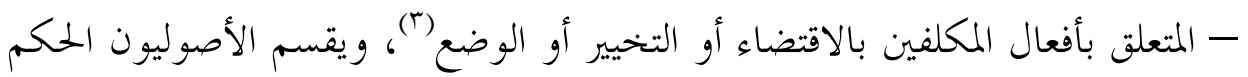
الشرعي إلى: تكليفي ووضعي.

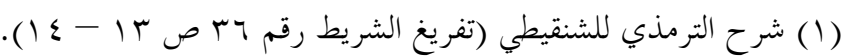

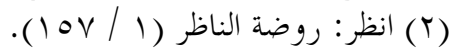

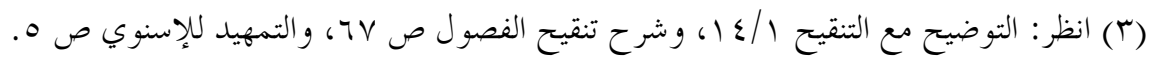




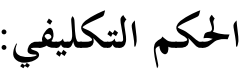

إذا طلب الشرع من المكلف فعل شيء: كصلاة الظهر والركعتين قبلها أو اجتناب شيء: كالربا والشبهات، سمي قضاء الشرع على ذلك الفعل حكما تكليفيا، ويدخل في الحكم التكليفي عند جمهور الأصوليين: تخيير الشرع للمكلف بين الفعل والترك؛ فيدخل في الحكم الشرعي التكليفي: الإيجاب، والندب، و الكراهة، و التحريم، والإباحة، وتسمى متعلقاةًا: الواجب، و المندوب، والمكروه، والمحرم، و المباح. و الواجب ينقسم بحسب أفراده إلى: واجب معين لا بديل له في حالة الاختيار: كصلاة الظهر، وواجب مخير ذي أفراد والمكلف مخير بين أفراده يختار أيها شاء: كخصال الكفارة، وينقسم الواجب - بحسب وقته - إلى غير محدد بالوقت، ومحدد بوقت، فيكون موسعا أو مضيقا، وأما بحسب الفاعل فما طلب من مكلف بعينه أو من كل واحد من المكلفين: كصلاة الظهر يسمى واجبا عينيا، وما طلب من الجميع بحيث يكفي فعل بعضهم: كصلاة الجنازة يسمى الواجب الكفائي، والمطلوب بالتبع الذي

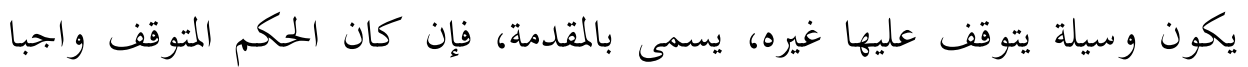
سميت وسيلته مقدمة الواجب: كالمشي يتوقف عليه فعل الواجب: وهو صلاة (الجمعة (1)

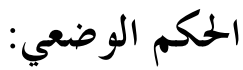

يعنى هذا المصطلح عند الأصوليين: نصب الشرع الشيء أو الفعل علامة على حكم، كما وضع الشرع زوال الشمس عن كبد السماء علامة على وجوب الظهر، ووضع الحيض علامة على عدم وجوب الصلاة، وعدم صحة الصوم. ومن أقسام الحكم الشرعي عندهم: السببية، والشرطية، والمانعية، ومتعلقاها:

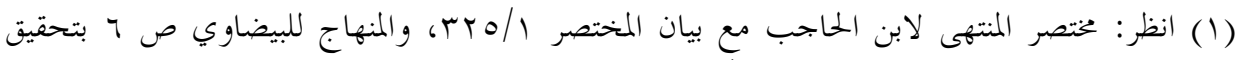

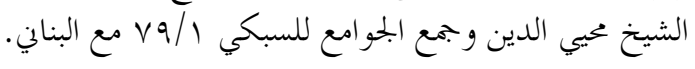
-OY _ 


$$
\text { السبب، و الشرط و المانع، وله أقسام أخرى. }
$$

ومن أقسامه: الصحة، والبطلان، و ونها: الإجزاء، والأداء، و الإعادة والقضاء، ولهرهاء

$$
\text { ومنها الرخصة و العزيمة (1). }
$$

المسألة الثانية: الأحكام الثرعية التكليفية المستنبطة من الحمديث

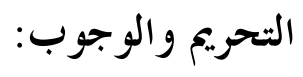

نظرا لورود النهي قطعي الثبوت واضح الدلالة على الحكم في هذا الموضع، فمن المتبادر اتفاق الصحابة الكرام على حرمة القعود و التقاعس عن الخروج إلى بني قريظة. ومن المتبادر كذلك: اتفاقهم على حرمة التباطؤ في الخروج. ورأت الطائفة الثانية: حرمة صلاة العصر في غير بني قريظة بدلالة صريح النهي

ويستلزم ذلك اتفاق الطائفتين على وجوب الخروج إلى بني قريظة، ووجوب

$$
\text { الإسراع قصدا إلى هنالك. }
$$

وأما وجوب فعل صلاة العصر في محلة بني قريظة بخصوصها، فإن الطائفة الأولى تقول: إنه مشروط بعدم تضييع وقت صلاة العصر، وأما الطائفة الأخرى فتقول بالوجوب مطلقا دون شرط. الاستحباب و الكر اهة:

القول بعدم وجوب صلاة العصر في بني قريظة؛ لانعدام شرطه الذي يحمل عليه فعل الطائفة الأولى يقتضي أن تكون صلاتها في بني قريظة من المندوب المستحب فعله، وأن يكون تركه مكروها، وهو مقتضى قاعدة سلم البعض هها، حيث قال: "الأمر إذا

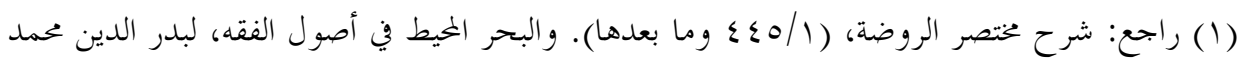

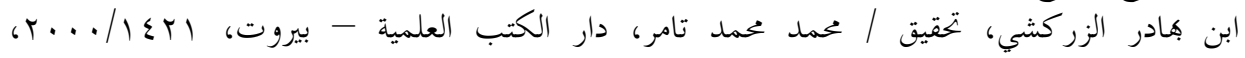

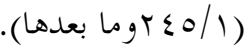


صرف عن الوجوب فإنه يحمل على الاستحباب ولا يحمل على الإباحة؛ لأن

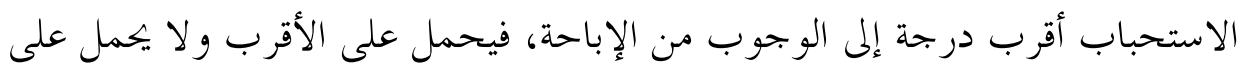
الأبعد وهو الإباحة إلا بقرينه، فإن جاءت قرينة تدل على أن ذلك الأمر للإباحة حمل على الإباحة" (1) لكن الحكم في هذه القاعدة لا يخلو من منازعة، ففي المسودة: "إذا صرف الأمر عن الوجوب جاز أن يحتج به على الندب أو الإباحة، وبه قال بعض الحنفية وبعض لهن الشافعية، ومنهم الرازي، وبعضهم قال: لا يحتج به" (؟). أقول: والذي أراه - و الله أعلم - أن كلتا الطائفتين حملت النهي على التحريم ويستلزم الوجوب بصفة عامة، لكن الطائفة الأولى رأت أن الوجوب متعلق بالقدرة، وأن انعدام القدرة في حق شخص يسقط الوجوب في حقه ويعيد الحكم إلى ما كان عليه قبل الوجوب، وهذا أشبه ما يكون بمسألة نسخ الوجوب - وليست من فروعها بعينها -، و فيها يقول الإسنوي: "إذا أوجب الشارع شيئا ثم نسخ.. فتلك الدلالة: هل زالت بزوال الوجوب أم هي باقية؟ اختلفوا فيه: فقال الغزالي: إها لا تبقى، بل يرجع

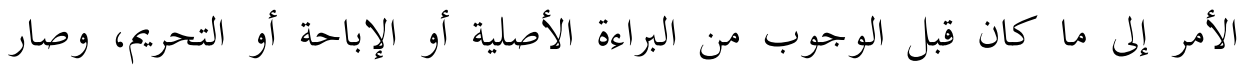
الوجوب بالنسخ كأن لم يكن، وقال الرازي و الجمهور : إذا باقية... وتلخص من ذلك: أنه إذا نسخ الوجوب بقي الندب أو الإباحة من الأمر مع ناسخه لا من الأمر فقط" (َ)

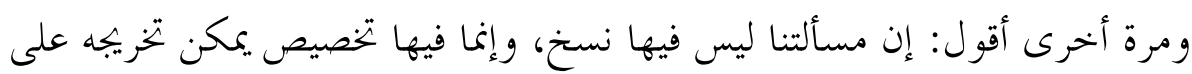
قول الأصوليين في نظيره وهو النسخ.

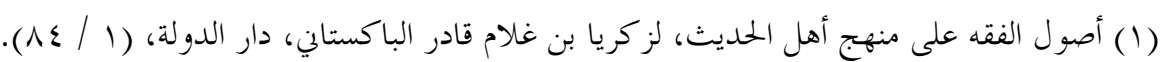

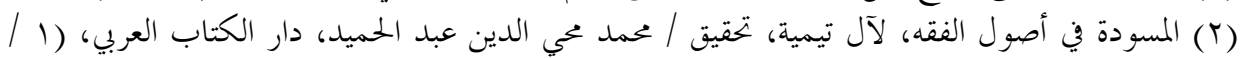

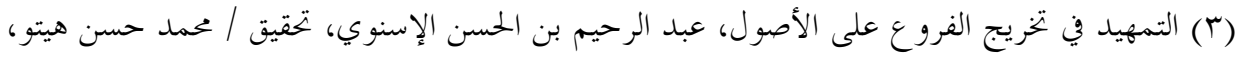

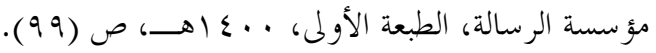




\section{المسألة الثالثة: أقسام الواجب في الحمديث الواجب المضيق والواجب الموسع:}

الواجب المضيق هو: الذي يكفي وقته لفعله دون زيادة ولا نقصان، مثل: صوم رمضان، ويقابله: الواجب الموسع الذي يزيد وقت أدائه على الوقت الكافي لفعله، كصلاة الظهر، يزيد وقت أدائها على فعلها، قال البيضاوي " الوجوب إن تعلق بوقت: فإما أن يساوي الفعل: كصوم رمضان وهو المضيق... أو يزيد عليه فيقتضي إيقاع الفعل في أي جزء من أجزائه لعدم أولوية البعض (1). و يتعلق بالواجب الموسع في دلالات حديث صلاة العصر في بني قريظة: أن صلاة العصر من الواجب الموسع، وأن وقتها يبدأ من انتهاء وقت الظهر، وينتهي وقتها بغروب الشمس.

وقد رأت الطائفة الأولى بقاءه منحصرا بين هاتين العلامتين فصلت العصر فيما بينهما، ورأت الطائفة الأخرى أنه وقت عصر ذلك اليوم بعينه قد امتد حتى وصول جميع المخاطبين بالأمر النبوي إلى بين قريظة.

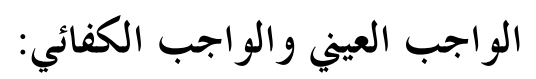

الواجب العيين: ما يجب على كل واحد من المكلفين: كالصلوات الخمس، و كذا ما و جب على واحد بعينه: كإمامة الحجيج في حق من عين لها، والواجب الكفائي أمر مهم طلب الشرع من المكلفين - مكجموعهم - فعله، مع عدم تحديد الفاعل بعينه، فالمطالب به غير معين، قال البيضاوي: "الوجوب إن تناول كل واحد: كالصلوات الخمس، أو واحدا معينا: كالتهجد، فيسمى فرض عين، أو غير معين: كالجهاد،

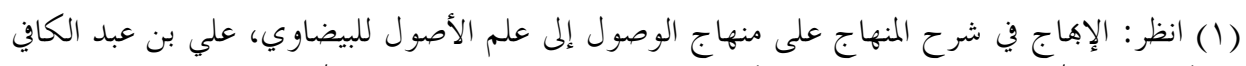

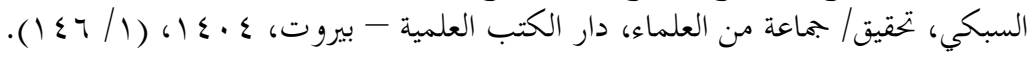


فرضا على الكفاية"|(1) .

وفرض الكفاية قد يتحول إلى فرض عين في بعض الحالات، منها: الخصار القدرة على القيام بالواجب في شخص أو أشخاص، ومثاله: إنقاذ المتعرض لغرق؛ فإنه يتعين في حق القادر على ذلك ممن يشاهدونه. و يتعين الواجب الكفائي على مكلف بتعيين الإمام له. ويتعلق هذا المبحث في دلالات حديث صلاة العصر في بين قريظة: أن الجهاد في أصله فرض كفاية، وقد تعين على المقصودين بهذا الأمر النبوي، خصوصا مع تحديد المخاطب بكل سامع مطيع، وقد كان واجب الجهاد في غزوة الخندق من الواجبات

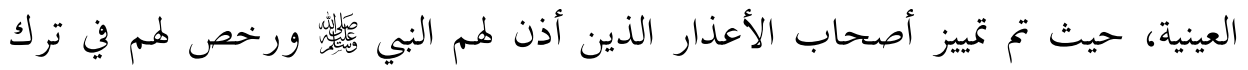
الجهاد، وثبت حكم الوجوب العيني في حق كل قادر لا عذر له. فالظاهر أن النداء قد خوطب به كل من وجبت عليه المشار كة في غزوة اللندق.

\section{مقدمة الواجب (الوسائل والمقاصد):}

اشتهر بين العلماء عبارة "ما لايتم الواجب إلا به فهو واجب"، وهي المعروفة عند الأصوليين .مقدمة الواجب، والحكم فيها أعم من الوجوب؛ لأنه "إذا توقف فعل المأمور به على شيء كان ذلك الشيء مأموراً به، فإن كان المأمور به و اجباً كان ذلك

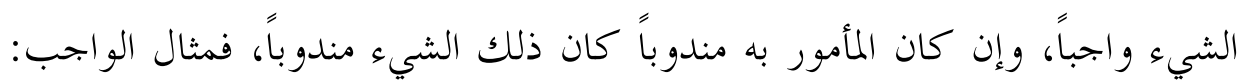
ستر العورة، فإذا توقف على شراء ثوب كان ذلك الشراء واجباً، ومثال المندوب: التطيب للجمعة، فإذا توقف على شراء طيب كان ذلك الشراء مندو باً"(r) و ويعبر عن هذا العموم: بأن الوسائل قد تعطى أحكام المقاصد، وومقدمة الواجب تنقسم قسمين:

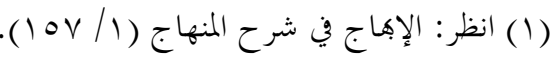

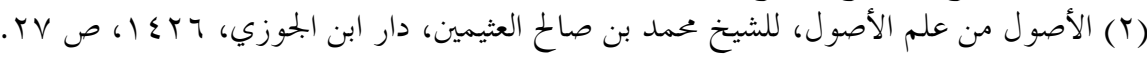

$$
\begin{aligned}
& \text {-07. }
\end{aligned}
$$


القسم الأول: أن يتوقف عليه وجود الواجب، وهو نوعان: أحدهما: أن يتوقف عليه شرعا: كالوضوء مع الصلاة، والآخر: أن يتوقف عليه عقلا: كالسير إلى الحج. والقسم الثاني: أن يتوقف عليها العلم بوجود الواجب لا نفس وجود الواجب، وذلك: إما لالتباس الواجب بغيره: كالإتيان بالصلوات الخمس إذا ترك واحدة ونسي عينها، فإن العلم بأنه أتى بالصالاة المنسية لا يحصل إلا بالإتيان بالخمس، وإما أن يكون لتقارب ما بين الواجب وغيره، بحيث لا يظهر حد مفرق بينهما، وذلك: كستر شيء

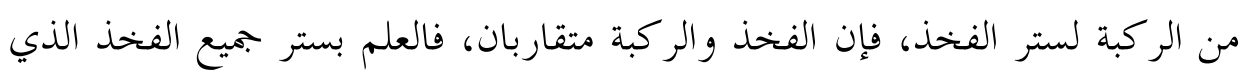
- هو واجب- إنما يكصل بستر شيء من الركبة للتقارب المذكور (1). ويتعلق بمقدمة الواجب من فو ائد هذا الحمديث ما يلي: 1 - أن الإسراع في المسير إلى بني قريظة واجب عقلا؛ لأن الاستجابة لأمر البي معني

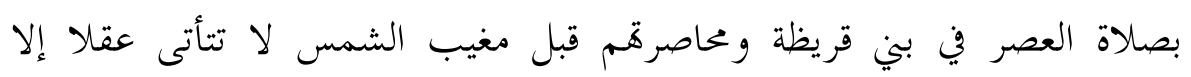

$$
\text { بالإسراع. }
$$

r - أن مقدمة الواجب لا بحب إلا مع القدرة عليها، يقول البضاوي: "وجوب

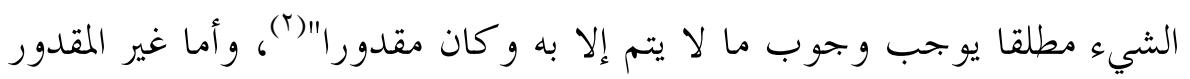
فلا يجب، وقد اعتبرت الطائفة الأولى هذا الشرط، فسارعت حسب لئ الطبه الطاقة والمستطاع، و اجتهدت في بلوغ أقصى ما يمكنها بلوغه من الطريق، وحينما

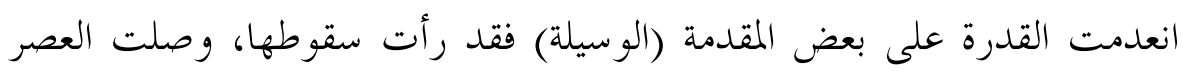

$$
\text { حيث بلغت بها قدرها. }
$$

r - أرى أن ابتداء النداء - في بعض الروايات(r) - بعبارة: "من كان سامعا مطيعا

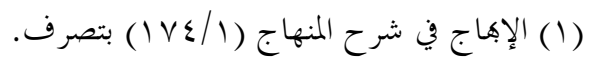

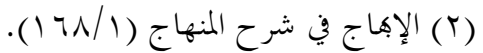

$$
\begin{aligned}
& \text { (T) سبق تخريجه في بداية البحث. }
\end{aligned}
$$


فلا يصلين العصر إلا في بني قريظة" لها علاقة بمقدمة الواجب؛ لأن السمع و الطاعة من الواجب المعلوم من الدين بالضرورة، وقد توقف هذا الواجب على الصلاة في

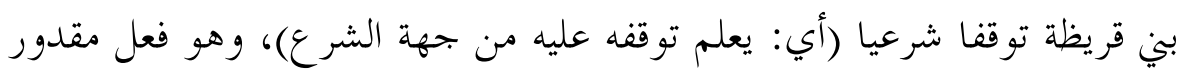

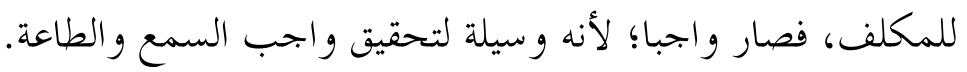

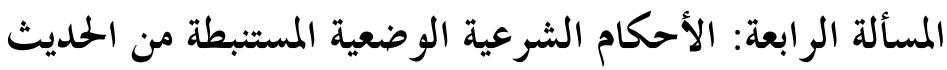

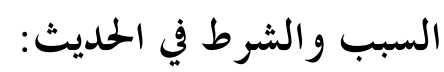

السبب: هو الوصف الظاهر المنضبط الذي يكون مناطا للحكم (1)، بمعنى: أنه يلزم من وجود السبب وجود المسبب، كما يلزم من عدم السبب عدم المسبب: كرؤية هلال رمضان، إذا وجدت الرؤية وجد الحكم وهو وجوب الصوم، وإذا انعدمت برت

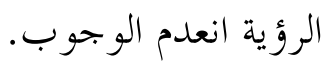
والشرط: ما يضاف له الحكم وجودا عنده لا وجوبا به(r)، وبعبارة أخرى هو: الوصف الظاهر المنضبط الذي يلزم من عدمه عدم المشروط ولا يلزم من وجودهه وجود المشروط ولا عدمه بالنظر لذات الشرط، ومن أحسن العبارات قول العلامة ابن قدامة: ما لا يوجد المشروط مع عدمه، ولا يلزم أن يوجد عند وجودهه (r)"، مثل استقبال القبلة

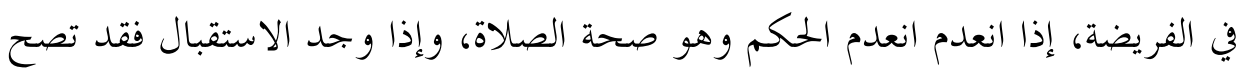
الصاة وقد لا تصح. ومواقيت الصلاة شروط عند الفقهاء لكنها عند الأصوليين معدودة في الأسباب؛ لانطباق تعريف السبب عليها. فدخول وقت صلاة العصر ذلك اليوم سبب كاف لوجوبها على اجتهاد الطائفة

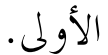

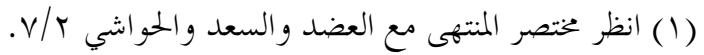

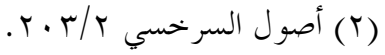

$$
\begin{aligned}
& \text { (r) (r) (Y) روضة الناظر (IV9/Y) }
\end{aligned}
$$


وعلى اجتهاد الطائفة الأخرى أصبح لها سبب مركب من أمرين: دخول وقتها، والوصول إلى بني قريظة، فمن وصل إليها بعد دخول الوقت وجبت عليت صليه صلاة العصر، ومن لم يصل إلى بني قريظة لم بتجب عليه العصر وإن دخل وقتها.

\section{الأداء و القضاء والتعجيل والإجزاء:}

الأداء عند الأصوليين: فعل العبادة في وقتها المحدد شرعا لفعلها (كصلاة الصبح في الوقت ما بين طلوع الفجر وطلوع الشمس)، والتعجيل: تقديمها على وقتها إذا أجاز

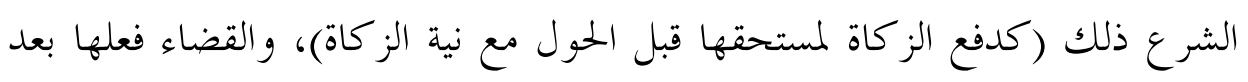
وقتها (كصلاة الصبح بعد طلوع الشمس)، والإجزاء هو: كون الفعل كافيا في

الخروج عن عهدة التكليف (1).

وصلاة العصر في الطريق أداء عند الطائفة الأولى، وأما الطائفة الأخرى فيجب عليها أن تعتبره تعجيلا صححه الشرع للعذر. وصلاتحا في بني قريظة قضاء لم يرتب عليه الشرع إثما للعذر عند الطائفة الأولى، وهي أداء عند الطائفة الأخرى. وصنا فيطه

وقد أجزأت كلا منهم صلاته، فلا يحتاج لإعادها، كما ثبت بالتقرير النبوي.

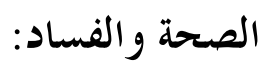
يعرف الأصوليون الصحة بأها: استتباع الغاية، وغاية العبادة: امتثال الأمر عند المتكلمين، وسقوط القضاء عند الفقهاء (r). وعدم الأمر بإعادة الصلاة يستلزم الحلكم بالصحة على صلوات جميع أفراد الطائفتين كلتيهما.

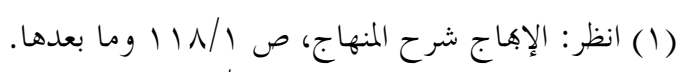

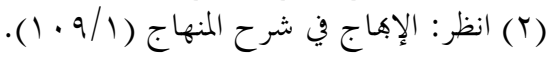




\section{العزيمة و الرخصة:}

يقصد بالعزيمة: الحكم الأصيل الذي يتوجب على المكلف امتثاله، ويقابلها الرخصة، فهي الحكم البديل الذي شرع تخفيفا على بعض المكلفين؛ لما قام هـم من أعذار، قال البيضاوي: "الحكم إن ثبت على خلاف الدليل لعذر فرخصة: كحل الميتة للمضطر، و القصر و الفطر للمسافر .. و إلا فعزيمة" (1). ويمكن أن يخرج على اجتهاد الطائفة الأولى القول بأن صلاة العصر في بني قريظة عزيمة، وأن صلاقَا في الطريق رخصة لذوي الأعذار الذين لم يتمكنوا من الوصول إليها قبل انتهاء وقت العصر.

المطلب الثالث : قضايا الاجتهاد و التقليد عند الأصوليين وعلاقتها بالحديث المسألة الأولى : قضايا الاجتهاد والتقليد عند الأصوليين يعرف علم أصول الفقه بأنه: "معرفة أدلة الفقه الإجمالية، وكيفية الاستفادة منها، وحال المستفيد" وبذلك تندرج بحوث الاجتهاد والتقليد في موضوع العلم، ويولي الأصوليون هذا الباب عناية خاصة، فيبحثون تعريف الاجتهاد وحكمه وشروط البحتهد ودرجات المجتهدين، وبحالات الاجتهاد، والأحكام المتعلقة به، كما يبحثون موضوع الفتوى وشروط الفتيا والمفتي وآداب الاستفتاء والإفتاء، ويهتم الأصوليون بقضايا التقليد وأحكام المقلد ودرجات المقلدين، وسأتناول فيما يلي ما يتعلق ببحوث الاجتهاد في حديث صالاة العصر في بين قريظة.

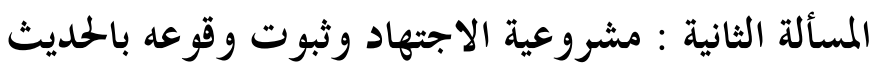
مشروعية الاجتهاد و حكمه: الاجتهاد فرض كفاية على الأمة، ويصبح فرض عين على من لم يوجد غيره عند 
عرض الواقعة، ويخرم على من لم يستوف شروطه، ويقول الشو كاني: "الاجتهاد في

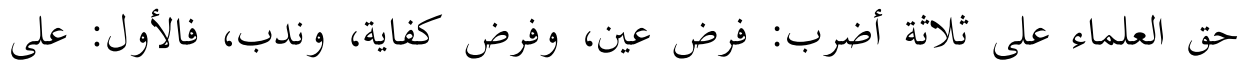

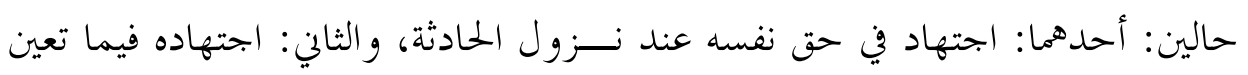

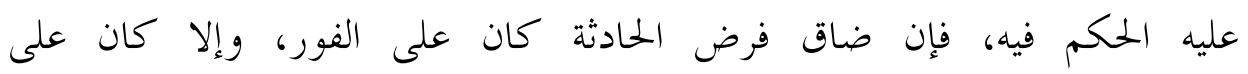
التر اخي.." (1). (1)

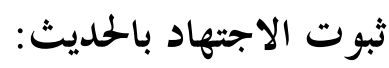

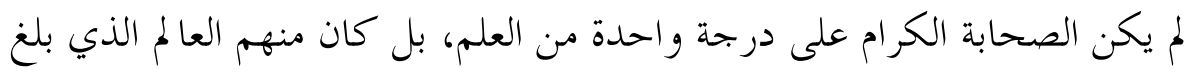

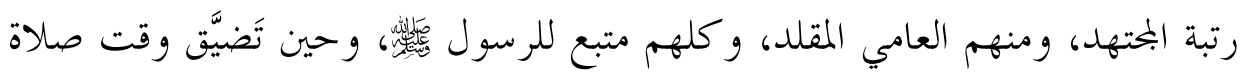

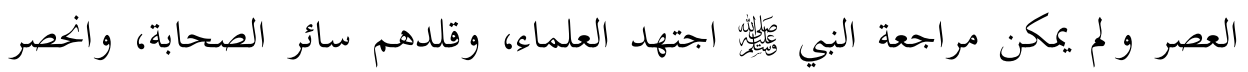

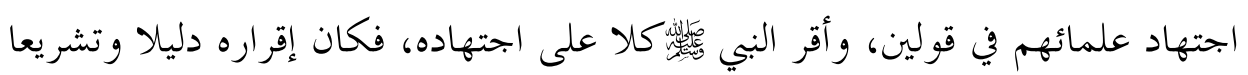
لالأمة.

\section{المسألة الثالثة :اجتهاد الصحابة في زمن التشريع وثبوت وقوعه بالحديث

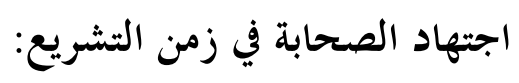

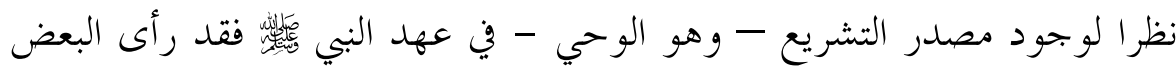

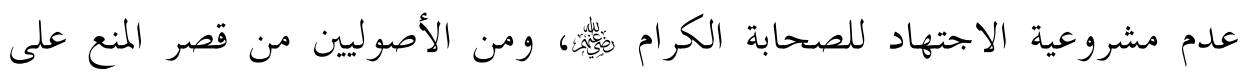

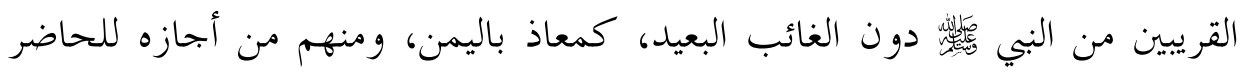

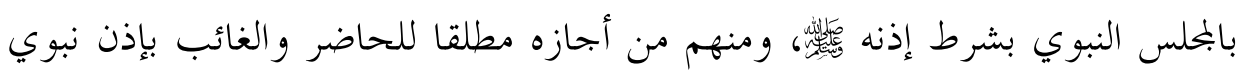

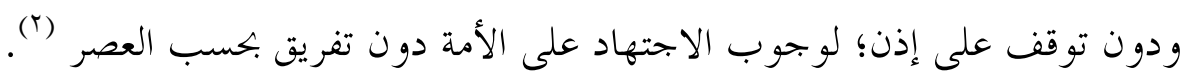

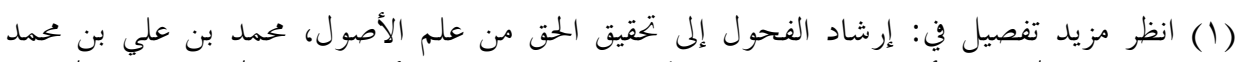

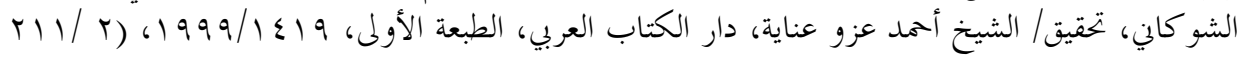

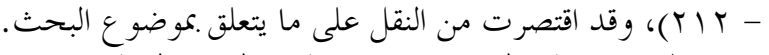

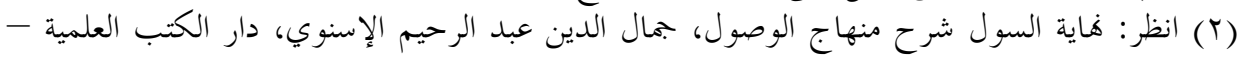

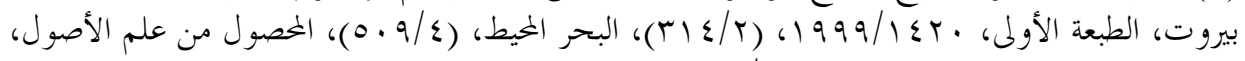

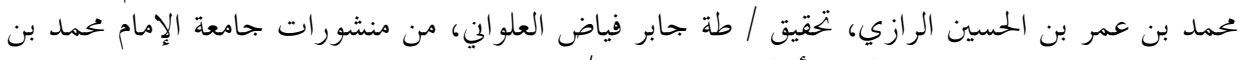

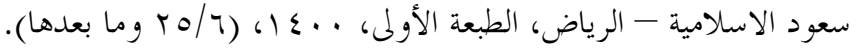




\section{ثبوت وقوع اجتهاد الصحابة بالحمديث:}

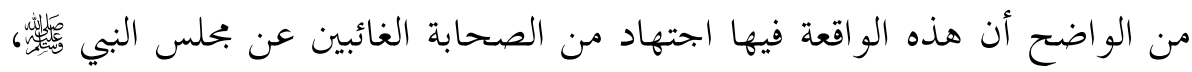

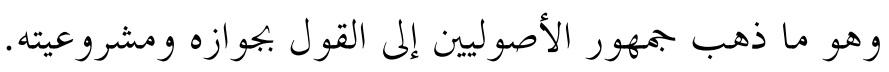

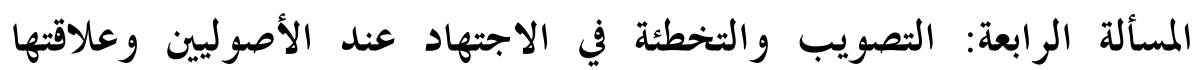

بالحديث

\section{التصويب والتخطئة في الاجتهاد عند الأصوليين:}

من المقرر عند جماهير الأصوليين: أن الحق واحد في كل مسألة اجتهادية، فمن اهتدى إليه فقد أصاب ويؤجر أجرين؛ لاجتهاده و إصابته، ومن لم يهتد إليه فقد إند

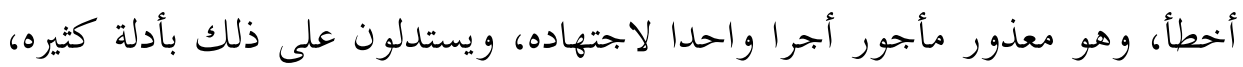

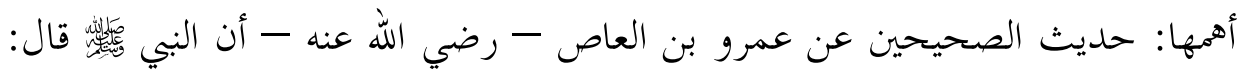

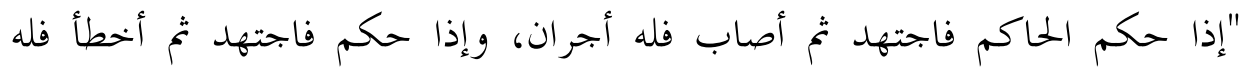
أجر" (1)

ومقابل قول الجمهور: أن الحق واحد في المسائل الاعتقادية والقطعية فقط، أما المسائل الفرعية العملية الاجتهادية فيجوز وصف كل من القولين المتضادين بالحق، ومن ثم فكل بحتهل فيها مصيب، وهذا القول معروف مشتهر، ويعزى للظاهرية و المعتزلة و بعض الحنفية (r)

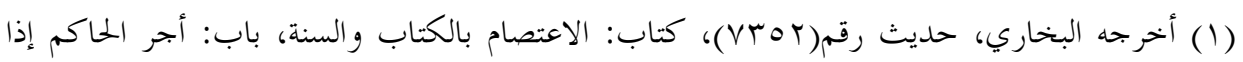

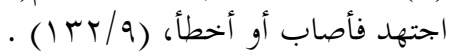

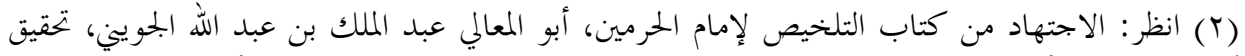

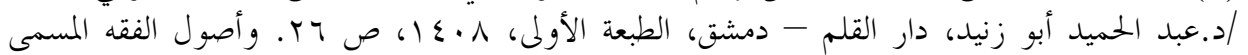

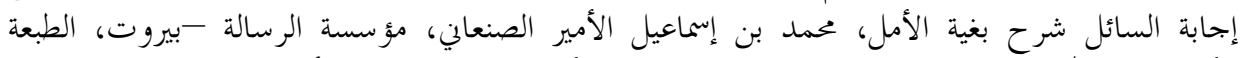

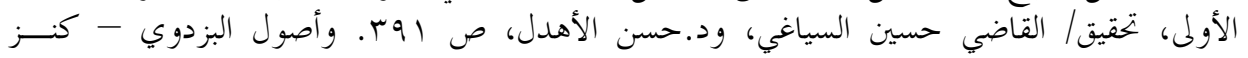

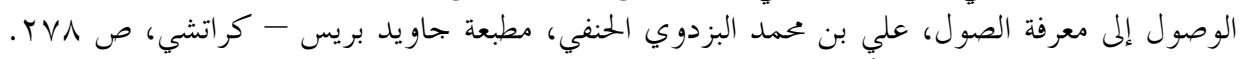

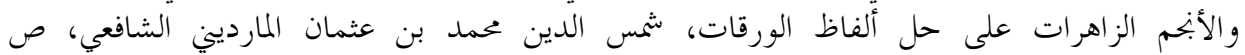

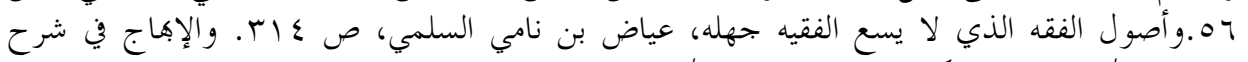

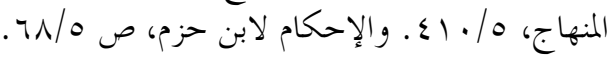




\section{التصويب و التخطئة في الحديث:}

ذكر بعض العلماء أن المصوبة يحتجون هذا الحديث (1)، لكن التحقيق: أنه لا دلالة

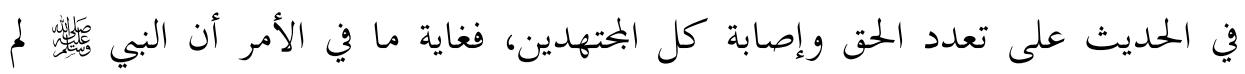
يعنف أحدا من الفريقين، وذلك متجه على القولين كليهما في التصويب والتخطئة؛ لأن البختهد المخطئ لا وزر عليه، ولا يلام ولا يعنف، قال النووي: "وين الحديث أنّه

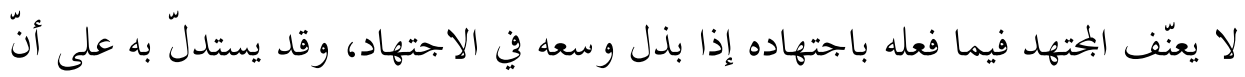

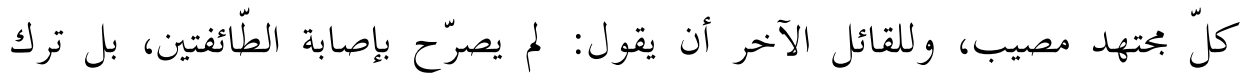
تعنيفهم، ولا خلاف في ترك تعنيف المجتها وإن أخطأ إذا بذل وسعه في الاجتهاد" (T)" يقول العلامة ابن كثير: "وقد اختلف العلماء في المصيب من الصحابة يومئذ من هو، مع الإجماع على أن كلا من الفريقين مأجور ومعذور غير معنف" (بآ). المسألة الخامسة : ثبوت العمل بمقتضى الاجتهاد وعدم الإعادة بالحديث

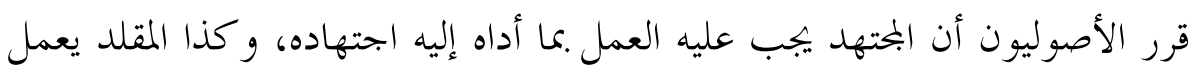

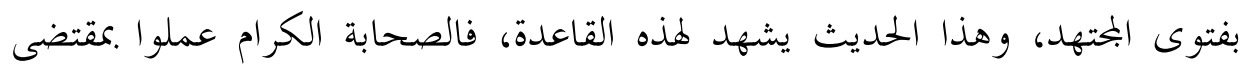
اجتهادهم؛ لما وقر في صدورهم من جواز ذلك، وقد صرحت الرواية بطريق النص على أن البي وحجة، كما تدل الرواية على أن من اجتهد اجتهادا صحيحا لا يجب عليه الإعادة، فذلك مقتضى السكوت النبوي؛ إذ لو وجد أمر بالإعادة لما كان سكوتا، كما أنه لم

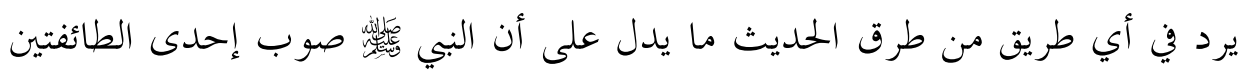

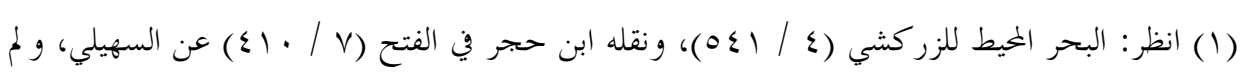
يسلمه له.

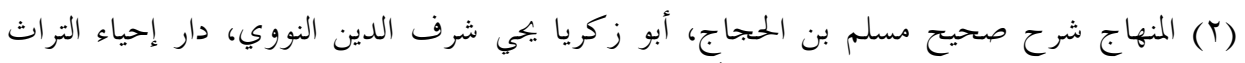

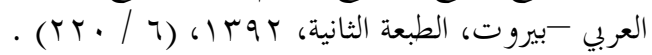

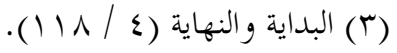


فيما بعد، أو أمر أحدا منهم بالإعادة وجوبا ولا ندبا، ولو كانت الإعادة واجبة على

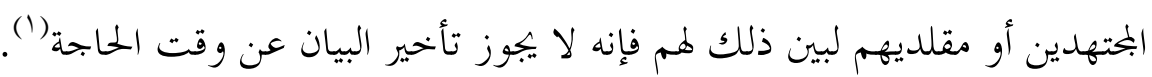
وقد استنبط العلامة ابن عبد البر من الحديث: القاعدة الأصولية الفقهية المشهورة: "لا ينقض الاجتهاد بالاجتهاد"، حيث يقول: "قال أبو عمر: هذه سبيل الاجتهاد على الأصول، عند جماعة الفقهاء؛ ولذلك لا يردون ما اجتهد فيه القاضي وقضى به إذا لم يرد إلا إلى اجتهاد مثله، وأما من أخطأ منصوصا فقوله وفعله عندهم مردود إذا ثبت بـ بـ

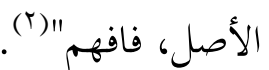

ومدار استنباطه على: أن الفريقين لم يؤمرا بالإعادة، لكن يرد على هذا الاستباط:

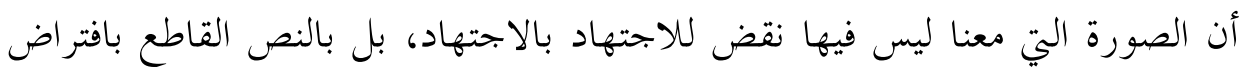
وقوعه حينئذ.

\section{المسألة السادسة: ثبوت قاعدة "لا ينكر المختلف فيه" بالحديث}

سطر الفقهاء هذه القاعدة العظيمة في كتب القواعد الفقهية، ومارسوا تطبيقاها كمراعاة آداب الاختلاف في حياهم ومؤلفاهم، حفظا للدين والدنيا؛ إذ لو جوز ذلك مع كون الاختلاف سنة كونية، وفطرة بشرية، اقتضتها طبيعة البشر في تفاوت المدارك

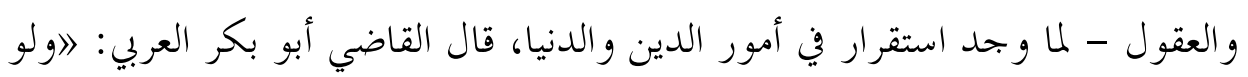

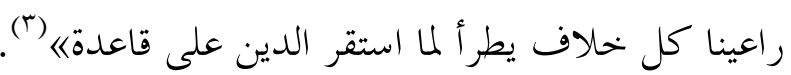

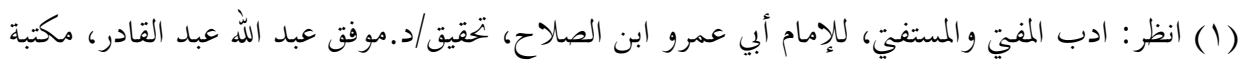

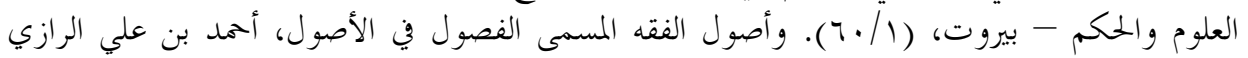

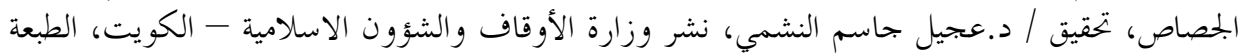

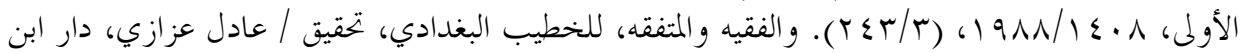

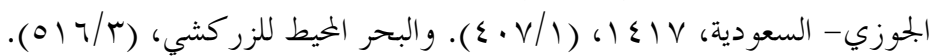

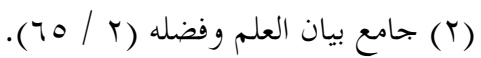

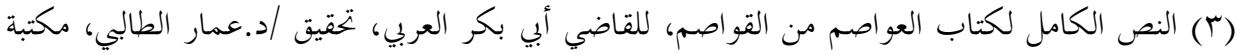

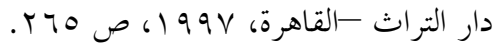


والمراد قطعا: ما ساغ فيه الاختلاف بأن احتمله الدليل الصحيح المقبول، فالمختلف فيه الذي لا ينكر هو الذي يقع في المسائل الظنية المجتهد فيها، حيث لا نص - قطعي الثبوت و الدلالة - ولا إجماع قطعيا كذلك، فحيث كان الحكم في المسألة غير

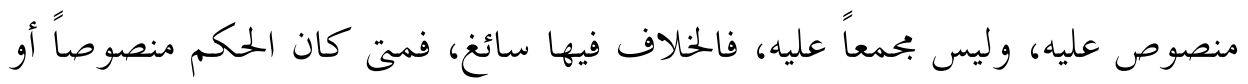
بحمعاً عليه إجماعاً معققاً، فالخلاف فيها غير سائغ؛ إذ ليست حينئذ محل اجتهاد و نظر. قال ييى بن سعيد: 》اما برح أولو الفتوى يفتون فيحل هذا ويحرم هذا، فلا يرى

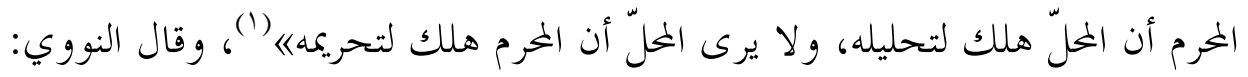

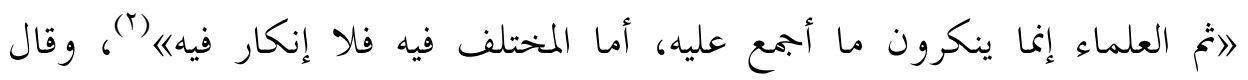
الزركشي: 》الإنكار من المنكر إنما يكون فيما اجتمع عليه، فأما المختلف فيه فلا إنكار فيه... و لم يزل الخلاف بين السلف في الفروع ولا ينكر أحد على غيره بحتهداً فيه،

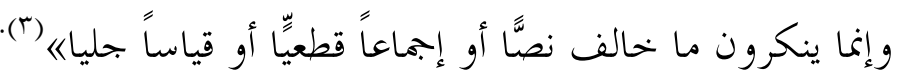
وهذه القاعدة ظهر تطبيقها في هذا الحديث من جميع الصحابة، وتوج ذلك عدم

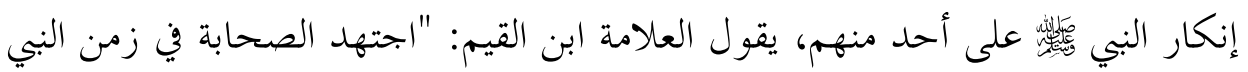
ئ وقال: لم يرد منا التأخير، وإنما أراد سرعة النهوض، فنظروا إلى المعنى، واجتهد آخرون وأخروها إلى بني قريظة، فصلوها ليلا، فنظروا إلى اللفظ.. وهؤلاء سلف أهل الظاهر

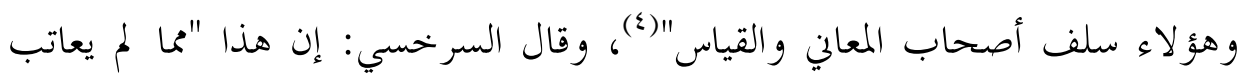

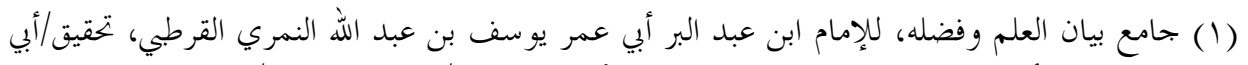

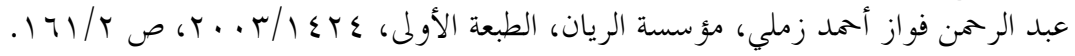

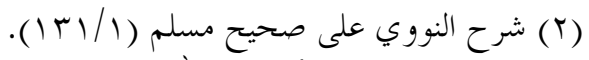

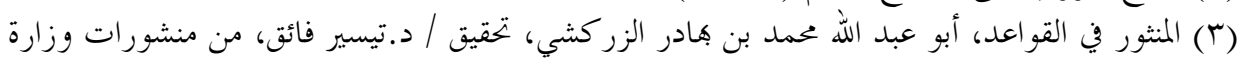

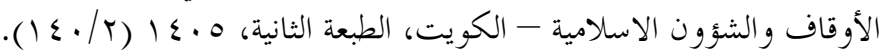

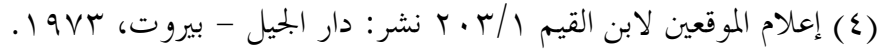


عليه" (1)

المسألة السابعة : استنباط جواز التقليد من الحديث

لا محيص عن القول بوجوب تقليد العامة للعلماء في الفروع الفقهية، وأن المقلد

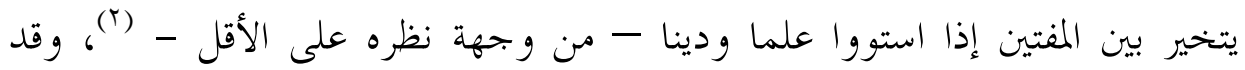
استنبط العلامة بدر الدين الزركشي من هذا الحمديث: جواز التقليد، وجواز تخير المقلد بين المفتين؛ لأن النبي

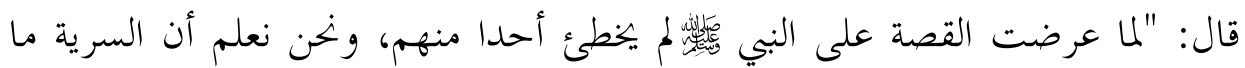
خلت عمن لا نظر له، و لا مفزع إلا تقليد وجوه القوم وعلمائهم، و كان ذلك المقلد مخير ا و باختياره قلد و لم يلحقه عتب و لا عيب" (). ** *

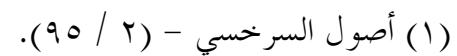

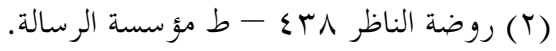

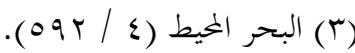




\section{المبـثث الثاني \\ قواعد الاستنباط من النصوص الهب \\ والترجيج بينها عند الأصوليين \\ وعلاقتها بالحلديث}

المطلب الأول: قواعد الاستنباط من النصوص عند الأصوليين وعلاقنها بالحديث المسألة الأولى: دلالات الألفاظ والصيغ عند الأصوليين نظرا لبناء استباط الأحكام الشرعية على النصوص القرآنية والأحاديث النبوية، فقد أولى الأصوليون دلالات الألفاظ والصيغ كامل العناية، فعقدوا بابا للحقيقة و المحاز، و آخر للوضوح والخفاء، وثالثا للعموم و الخصوص، ورابعا للأمر و النهي.. وغيرها. و سأحاول ما استطعت الربط بين استنباط الصحابة من حديث صلاة العصر في بني قريظة وبين مصطلح الأصوليين.

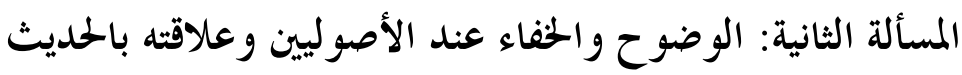

$$
\text { الوضوح و الحففاء عند الأصوليين: }
$$

نــزـل القرآن الكريم "بلسان عربي مبين"، ونظرا لاتساع الدلالات على المعاني في كلمات اللغة العربية الفريدة، وتفاوت عقول المكلفين وعلومهم ومداركهم، فإن النصوص تتفاوت وضوحا وخفاء في الدلالة على معانيها، وقد عني الأصوليون بباب الدلالات عناية عظيمة، حتى أطلق على هذا الباب في العصر الحديث "علم الدلالة". ويقسم الحنفية دلالات النصوص وضوحا وخفاء ثمانية أقسام، فأعلاها وضوحا: الخكمم، ويليه: المفسر ثم النص ثم الظاهر، وأقلها خفاء: الخفي ثم المشكل تم البحمل ثم المتشابه وهو أعلى درجات الخفاء (1).

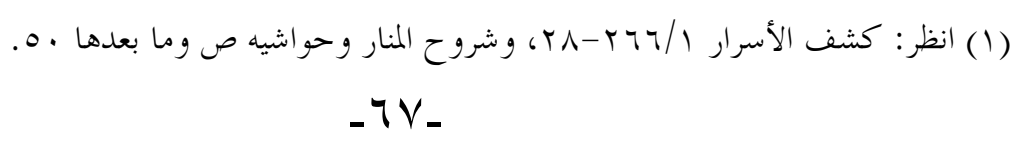


وأما جمهور الأصوليين - واشتهر منهجهم بطريقة المتكلمين - فيقسموفا أربعة أقسام: أعلاها وضوحا: النص ثم الظاهر ثم المؤول ثم البحمل وهو أكثرها خهفاء (1). القطعية و الظنية في الحديث: بالنسبة للصحابة الكرام فالخطاب النبوي قطعي الثبوت عندهم جميعا، لكن دلالته اجتهادية قطعا، بدليل الاختلاف فيها ابتداء، ثم تقرير الشرع على ثمرة الخلاف انتهاء، ولا يقر الاجتهاد الذي يخالف نصا قطعي الدلالة.

\section{استنباط المصطلح الأصولي المتفق مع تأخير الصلاة:}

المصلون في بين قريظة رأوا اللفظ النبوي واضحا لا يحتمل غير مدلوله، و كذلك لا يحتمل تخصيصا ولا نسخا، فربما يتبادر أهم يرونه من النص باصطلاح الجمهور ومن الخكم باصطلاح الحنفية، غير أن الفيصل في تطبيق المصطلح ليس ما يراه أحد المحتهدين، بل مدلول اللفظ ذاته واحتماله للمعاني التي يقبلها غيره من المجتهدين، وهذا الحديث احتمل الدلالة على ما رآه الفريق الآخر، فيكون من الظاهر على المصطلحين.

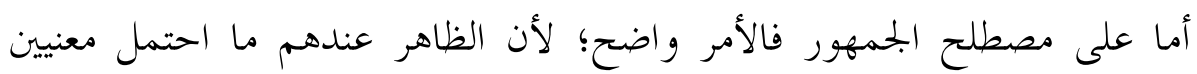
فأكثر، وتبادر منه المعنى المراد به أو المرجح عند المستدل، يقول ابن قدامة: "الظاهر: ما يسبق إلى الفهم منه عند الإطلاق معنى مع بحويز غيره، وإن شئت قلت: ما احتمل معنيين هو في أحدهما أظهر" (؟). وأما على مصطلح الحنفية فالظاهر: الواضح بصيغته، و النص: ما ازداد وضوحا بعبارة من المتكلم، يقول البزدوي: "الظاهر: اسم لكل كلام ظهر المراد به للسامع

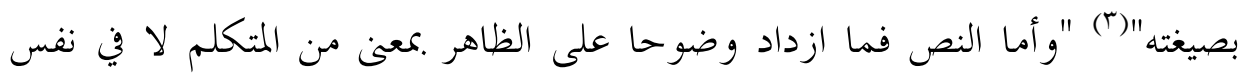

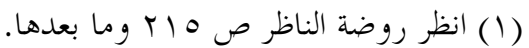

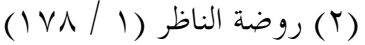

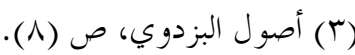


الصيغة"(1) "وأما المفسر: فما ازداد وضوحا على النص: سواء كان بمعنى في النص أو بغيره انسد به التأويل وباب التخصيص إلا أنه يحتمل النسخ والتبديل"((ז) "فإذا ازداد قوة وأحكم المر اد به عن احتمال النسخ و التبديل سمي محكما"(ب). ولا شك أن المعنى المختلف فيه في الحديث (وهو قصد بحرد الإسراع أو خصوصية مكان الصلاة) لم يوضح قط من جهة المتكلم بل

\section{استنباط المصطلح الأصولي المثفق مع الصلاة بالطريق:}

فهم الطائفة الأولى للخطاب النبوي يدل على: أنه عندهم من قبيل المؤول

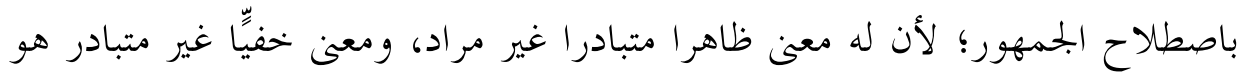
المراد، وهذه سمة المؤول، كما أن تخصيص العام نوع من التأويل عند الأصوليين، يقول الآمدي: التأويل "حمل اللفظ على غير مدلوله بدليل يعضده"(؛) ويقول: "وعلى هذا فالتأويل لا يتطرق إلى النص ولا إلى ابلممل و إنما يتطرق إلى ما كان ظاهر الا غير" (ه). وباصطلاح الحنفية يكون - على تقسيم البزدوي - من الخفي وهو: الذي يخفى معناه لعارض زائد على الصيغة لا ينال إلا بالطلب ويحتاج إلى دليل من خحارجه، يقول البزدوي: "فالخفي: اسم لكل ما اشتبه معناه، وخفي مراده بعارض غير الصيغة، لا ينال إلا بالطلب.. وهو في مقابلة الظاهر.. و المشكل يقابل النص، و ابحمل يقابل 


\section{الوضوح والخفاء بعد عصر الصحابة:}

أما بالنسبة لمن بعد الصحابة فلا يجوز للظاهرية أن يعدوا الخطاب النبوي من قبيل النص أو الحكمم؛ لثبوت الإقرار النبوي على صلاحيته للتأويل، فلا مفر من أن يعدوه من قبيل الظاهر، وأما غير الظاهرية فيرونه من المؤول، ومن يرى التوقف في الحكم

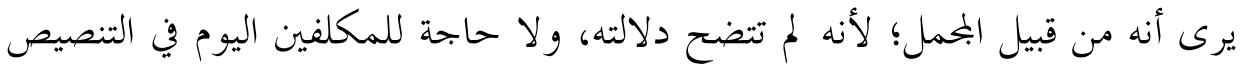
على ما يرفع الإجمال، كما لم يرفع في حق الصحابة الكرام الذين وجه إليهم الخطاب شفاهة، وانتهى وقت العمل به، فزالت التهاجة إلى بيانه. المسألة الثانية: الحقيقة والجاز عند الأصوليين وعلاقتهما بالحديث الحقيقة والجاز عند الأصوليين: يقصد بالحقيقة: دلالة اللفظ على ما وضع له، ويقصد بالمحاز: استعمال اللفظ في غير ما وضع له؛ لعلاقة بين المعنيين، المعنى الذي وضع له اللفظ، والمعنى الذي استعمل

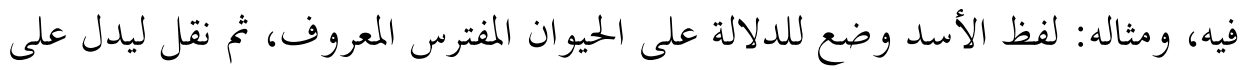
الرجل عند وجود الشجاعة، وهي العلاقة بين الرجل الشجاع والأسد، قال ابن السبكي: "أما الدلالة باللفظ فهي: استعمال اللفظ إما في موضوعه وهو الحقيقة، أو

$$
\text { [في] غير موضوعه لعلاقة وهو البحاز"(1). }
$$

و البحث في هذه المسألة مبين على القول بيجواز هذا النوع من المحاز.

\section{الحديث وعلاقته بالحقيقة و الجماز:}

حمل بعض الباحثين اجتهاد الطائفتين في حديث صلاة العصر في بني قريظة على

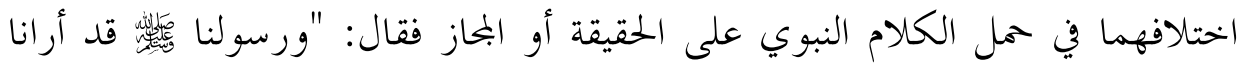
النموذج الأمثل في فهم النص على حقيقته أو على بحازه في حديثه المشهور حين قال 
للجنود بعد أن كفى الله المؤمنين القتال في غزوة الأحزاب وأمر بالتوجه إلى بني قريظة

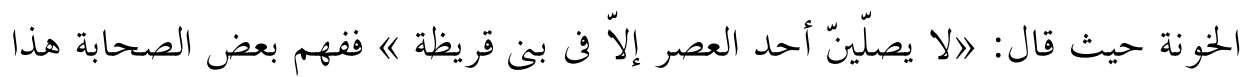
الحميث على معناه الحقيقى بحيث إذا جاء وقت العصر قبل أن يصلو إلى بني قريظة

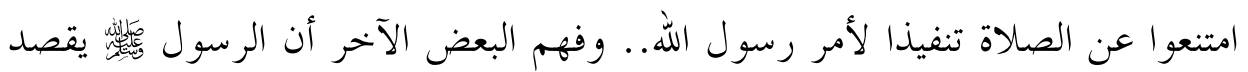
بنهيه هذا الإسراع في الوصول إلى بنى قريظة لمباغتتهم وحين جاء موعد صلاة العصر صلوها في الطريق"(1)، وقد أشار إلى هذا العلامتان أبو حيان وابن عطية بقولمما:

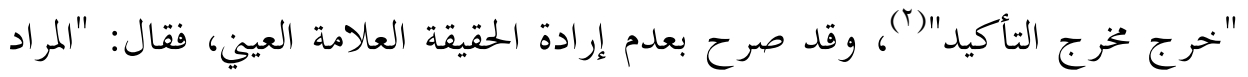
من قوله لا يصلين أحد لازمه، وهو الاستعجال في الذهاب إلى بني قريظة، لا حقيقة ترك الصلاة أصلا، و لم يعنفهم رسول الله على مخالفة النهي؛ لأهم فهموا منه الكناية

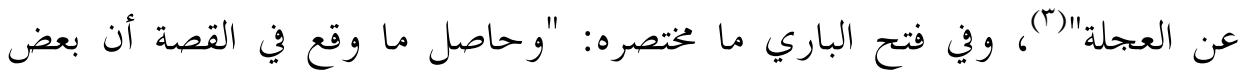
الصحابة حملوا النهي على حقيقته.. و البعض الآخر حملوا النهي على غير الحقيقة وأنه

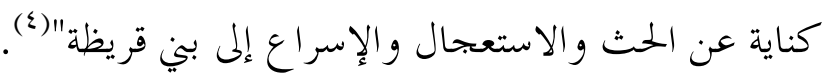
وتخريجا لاجتهادهم على قو اعد الأصول، أقول:

- صرح الأصوليون بأن من المحاز التعبير عن المعنى المراد بلازمه، بل دلت ولت عبارة بعضهم على أن هذا أصل العلاقات في البماز، يقول صدر الشريعة: "مبنى المحاز على إطلاق اسم الملزوم على اللازم، والملزوم أصل، واللازم فرع" (•). r - يمكن اعتبار المسببية هي علاقة المحاز، فيقال: عبر بالمسبب وهو الصلاة في بين

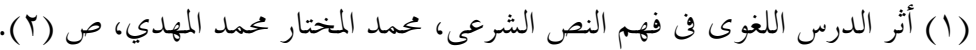

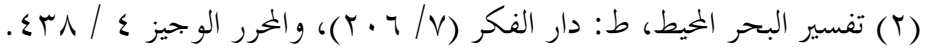

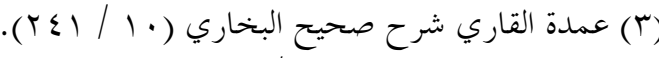

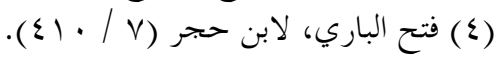

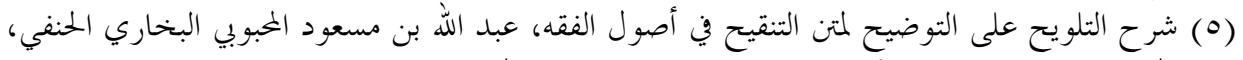

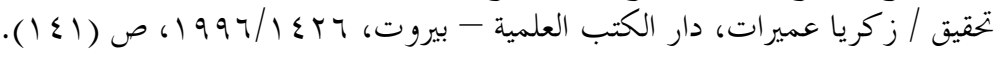


قريظة، وأراد السبب وهو الإسراع بالنفير، والسببية والمسببية من علاقات المحاز المعتبرة.

r- لا خفاء في أن اللفظ النبوي يدل بطريق المطابقة والحقيقة على وجوب الصلاة في بين قريظة، ومع ذلك فلا خفاء في استلزامه وجوب التعجيل والمباغتة، فقهمت الطائفة الأولى: أن التعبير بالملزوم (الصلاة) مراد به اللازم (التعجيل) أصالة، ورأت الطائفة الأخرى: أن الحقيقة هي المرادة أصالة وكل ما سواها فلا يلغيها وإن كان مقصودا. ولا تخفى العلاقة بين التعبير النبوي والكناية في مصطلح البلاغيين، فأشهر الكنايات عندهم: فلان كثير الرماد، جبان الكلب، وذلك عند إرادة نسبته للكرم؛ لأن كثرة الضيفان، وتعدد الطهي يلزم منه كثرة الرماد، كما يلزم منه جبن الكلب؛ لاعتياده على الضيوف، فكذلك إذا قلنا فلان صلى العصر يومئذ في بني قريظة يلزم منه أنه أسرع و تعجل. و الكناية عند البلاغيين نوع من الجماز في اصطلاح الأصوليين. المسألة الثالثة: العام والحخاص عند الأصوليين وعلاقتهما بالحديث

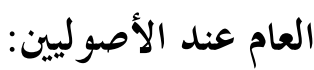
العام هو: اللفظ الذي يشترك في مدلوله أفر اد، ويتناولها جميعا دفعة واحدة، فيصدق

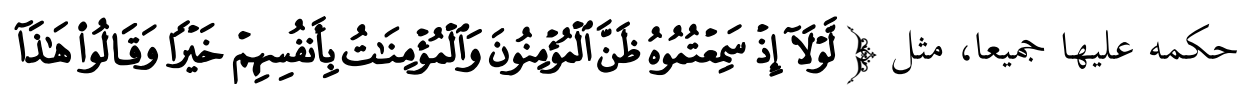

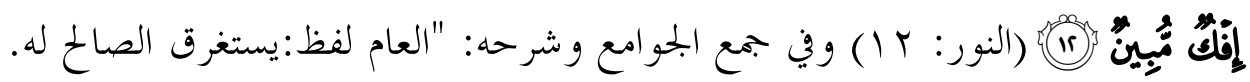
أي: يتناوله دفعة واحدة من غير حصر" (1).

(1) شرح جمع الجوامع لابن السبكي، للعلامة جلال الدين محمد بن أحمد الخلى، مع حاشية البناني، بتصرف / 
فإذا استثني من حكمه فرد أو بعض أفراده سمي عاما خصصوصا، مثل حديث: " كل

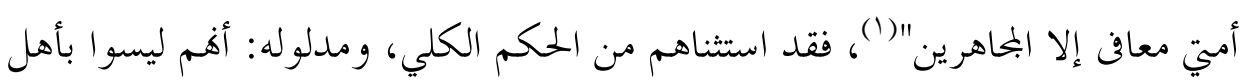
عافية.

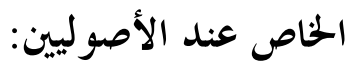

الخاص قد لا يشترك في مدلوله أفر اد، بل يدل على فرد و احد، مثل: زيد، ومكة،

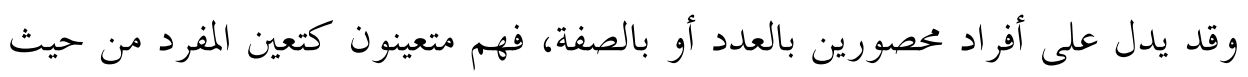

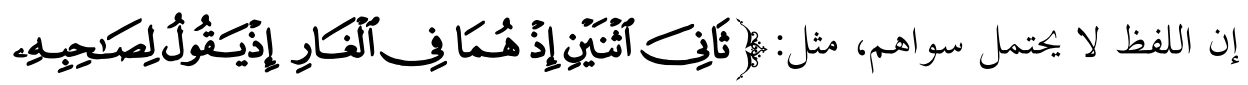

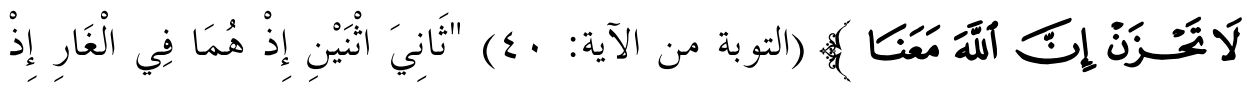

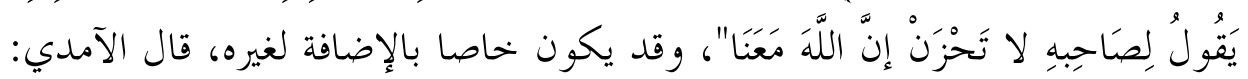
"والحق في ذلك أن يقال: الخاص قد يطلق باعتبارين: الأول: هو اللفظ الواحد الذي لإِ لا يصلح مدلوله لاشتراك كثيرين فيه: كأسماء الأعلام من زيد وعمرو ونهوه، و الثاني:

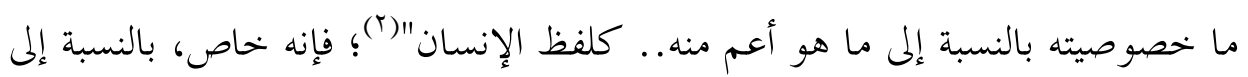
لفظ "الحي" أو "الحيوان"؛ لأن لفظ "الحي" يقال على مدلول "الإنسان" وعلى غيره

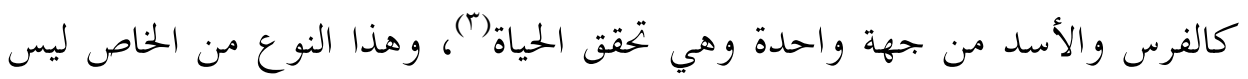
بالخاص الاصطلاحي عند الأصوليين.

المسألة الر ابعة: تناول التكليف لعموم المخاطبين في الحمديث

\section{كظ "أحد" وعلاقته بصيغ العموم:}

كلمة "أحد" لفظ مفرد نكرة، وقع في سياق النفي؛ لأنه فاعل للفعل المنفي، والنفي

(1) صحيح البخاري، كتاب: الأدب، باب: ستر المؤمن على نفسه، رقم الحديث (79 7)، ص (1 /

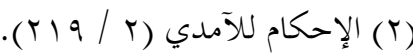

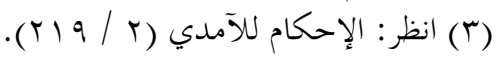


ليس خبريا هنا، بل هو ناتج عن أسلوب النهي الإنشائي، ومدلوله قصد نفي وقوع

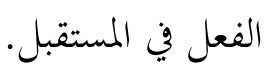
و النكرة الواقعة في سياق النفي إحدى صيغ العموم، بل تعد من أقوى الصيغ في الدلالة على العموم، وقد نص على ذلك الحافظ العلائي (1). دلالة العموم في لفظ "أحد": بحسب دلالة العموم في لفظ "أحد" فإنه عام يشمل جميع المكلفين الصادر إليهم الخطاب، وهم الذين وجب عليهم الجهاد، و العام يقبل التخصيص، فيكون عاما خصوصا، فلا يمنع عموم لفظ (أحد) من استثناء بعض المكلفين بالنفير من عمومه،

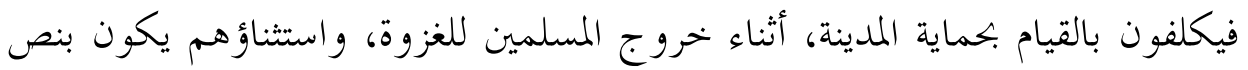
جديد، كما لا يمنع من استثناء من طرأ عليهم العذر.

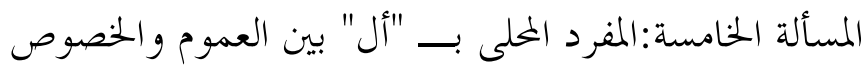
لفظ " العصر" مفرد محلى بـــ "أل" فهو صالح للعموم و الخصوص بحسب دلالة لام التعريف، فإن كانت للجنس دل على العموم، مثل قولنا: "المؤمن القوي خير وأحب

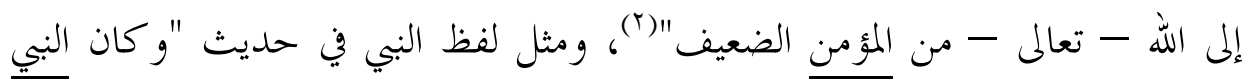
يبعث إلى قومه خاصة وبعثت إلى الناس عامة"(") وأما إن كانت اللام للعهد فيدل على

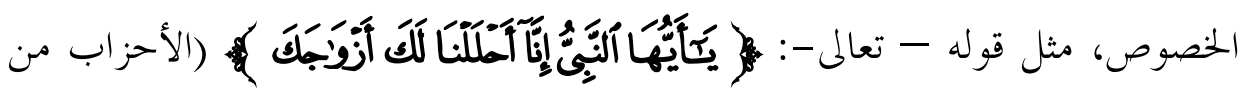

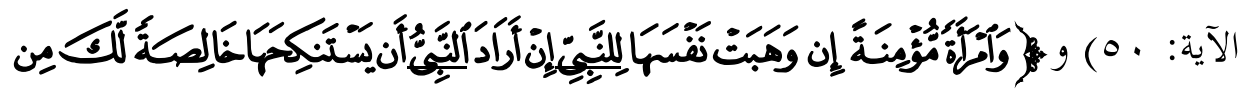

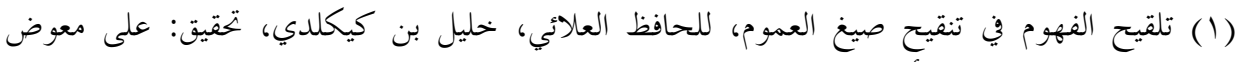

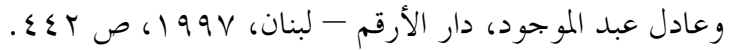

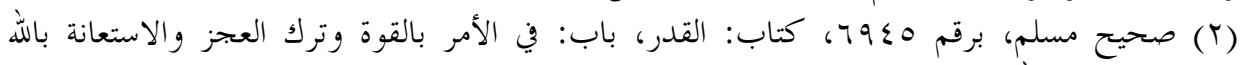
وتفويض المقادير لله (1 / T به م).

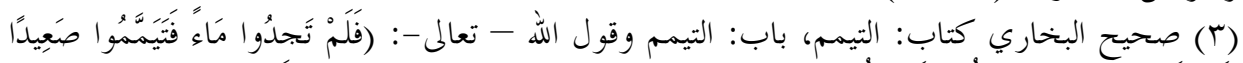

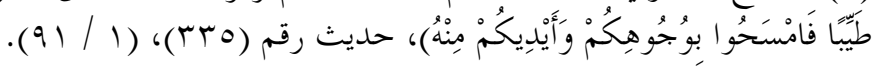




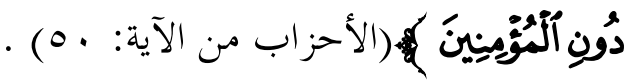

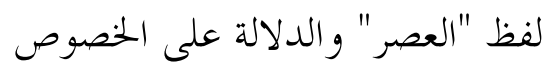

لفظ "العصر" في الحديث لا يحتمل إلا الدلالة على الخصوص؛ لأنه يقصد به معين

$$
\begin{aligned}
& \text { لا يحتمل الشركة في مسماه، ولا يصدق الحكم إلا على ذلك العصر بعينه. } \\
& \text { المسألة السادسة: لفظ "بني قريظة" بين العموم و الخحصوص }
\end{aligned}
$$

لفظ "بني قريظة" مكون من كلمتين، الأولى (بنو) وهي جمع مضاف، و الثانية "قريظة" علم يدل على مفرد وهو مضاف إليه، و الجمع المضاف من صيغ العموم، مثل:

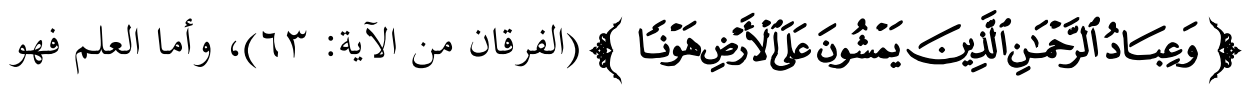
من الخاص. والكلمة المحذوفة والتي يقتضيها السياق فهي كلمة "موضع" أو ما ينوب عنها، فالتقدير فلا يصلين العصر إلا في موضع بين قريظة، وهو من الخاص، و الحلكم الذي يتعلق بذلك هو تحديد مكان الصلاة، وقد تم توضيحه في موضعه من البحث. المسألة السابعة: إجراء العموم وتخصيص العام في الحديث

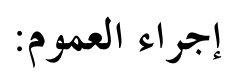

اللفظ الوحيد الذي يتعلق به استباط الأحكام الشرعية من ألفاظ العموم الواردة

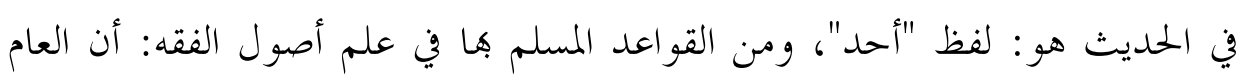
يجري على عمومه ما لم يقم دليل التخصيص، وفي هذا إجراء للنص على ظاهره؛ لأن "ظاهر النصوص: هو: ما يتبادر منها من المعاني بحسب ما تضاف إليه وما يحتف هـا

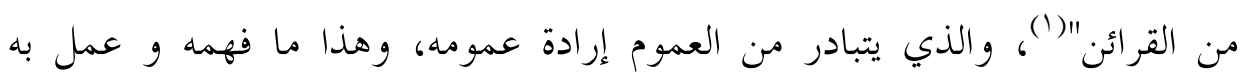

(1) تقريب الثدمرية، للشيخ/ عمد بن صالح العثيمين -رحمه الله-، دار ابن الجوزي، السعودية، الطبعة الأولى، 9 إـا، ص (00). 
الفريق الأول الذي لم يصل العصر إلا في بني قريظة بعد أن خرج وقتها ودخل وقت المغرب، فقد رأوا أن هذه الصلاة في حق جميع المكلفين الصادر إليهم الخطاب لا يجوز إيقاعها إلا في بني قريظة(1) وفهم النصوص الواردة في الكتاب و السنة بمعناها المتبادر إلى الذهن - من وجهة نظر تلك الطائفة - أولى من صرف هذه النصوص عن ظاهرها، وبيانا لمذهبهم يقول العلامة ابن حزم: "ولو أننا حاضرون يوم بني قريظة لما صلينا العصر إلا فيها، ولو بعد نصف الليل" (؟). تخصيص العموم في الحمديث:

الفريق الذي صلى في الطريق لم يجر النص على ظاهره، بل تأوله بصرفه عن ظاهره إلى معنى آخر؛ استبعادا لقصد الظاهر؛ فإنه ليس لأي صلاة في بني قريظة فضيلة عن غيرها، ناهيك عن كون الأصل أهم سيصلون في المسجد النبوي الذي تشد إليه الرحال، ويضاعف فيه أجر الصلاة. ويمكن تخريج هذا التأويل على أنه تخصيص للعموم بإخراج بعض أفراد العام، فلا ينطبق عليهم حكمه، ويكون التأويل: كل من بلغه النداء يجب عليه الإسراع، بحيث يصلي العصر في وقتها في بني قريظة، ومن لم يتمكن من ذلك لأي عذر فيجب عليه الإسراع ما استطاع، ولا يفوت على نفسه صلاة العصر في وقتها.

\section{نوع المخصص:}

يمكن تفسير هذا النوع من التخصيص بأنه: تخصيص بالسياق، ويقصد به: قرائن الحال و المقال المصاحبة للدليل، والقرينة الحالية هنا: أن تحقيق المقصود من هذا الأمر يكون بإسراع السير؛ لإدر اك بني قريظة وحصارهم قبل مغيب الشمس.

(1) انظر: فتح الباري، للحافظ ابن رجب، زين الدئ الدين عبد الرحمن البغدادي، تحقيق/ طارق عوض الله،

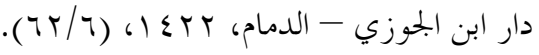

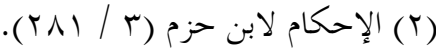


وعبر بعض العلماء عن هذا النوع من التخصيص بأنه: "استنباط معنى من النص

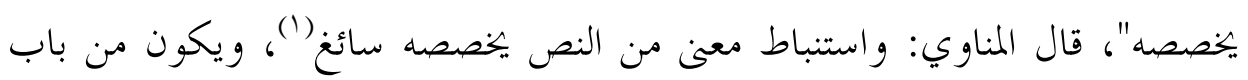
التخصيص بالمتصل (ז)؛ لأنه مستنبط من ذات النص، بالإضافة إلى الأدلة المنفصلة

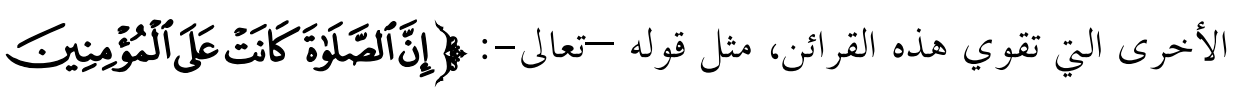

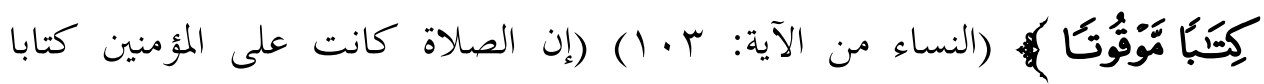
موقوتا).

\section{تخصيص الحمديث للأدلة الأخرى:}

الفريق الذي صلى في بني قريظة جعل هذا الحديث خخصصا لعموم الأدلة الموجبة لإيقاع كل صلاة في وقتها، وعلى ذلك فهو عندهم من التخصيص بدليل مستقل منفصل، وهو النص الثابت في هذا الحمديث. المسألة الثامنة: الأمر والنهي عند الأصوليين تمثل الألفاظ والأساليب العربية القوالب التي تحدد معالم المعاني، والأمر: هو الصيغة الأصيلة في طلب الفعل، كما أن النهي هو الصيغة الأصيلة في طلب ترك الفعل واجتنابه، ويعنى الأصوليون ببيان صيغ الأمر و النهي الصريمة و الضمنية، كما يعنون بالدلالة الأصيلة للأمر والنهي، أهي الوجوب والهئ والتحريم أم غيرهما؟ والمعاني الأخرى التي تدل عليها صيغتا الأمر والنهي عند وجود قرينة تحدد المراد: كالتهديد والتخيير، ثم

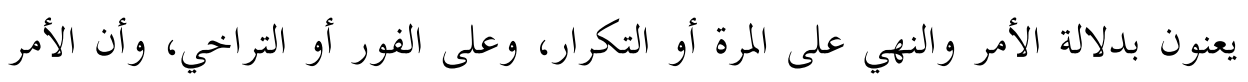
بالشيء هي عن كل ضد له، والشيء إذا كان له ضد واحد فالنهي عنه أمر بذلك لهرك

(1) فيض القدير شرح الجامع الصغير: لزين الدين المناوي، دار الكتب العلمية، بيروت، الطبعة الأولى،

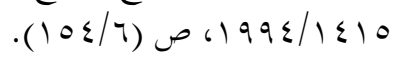

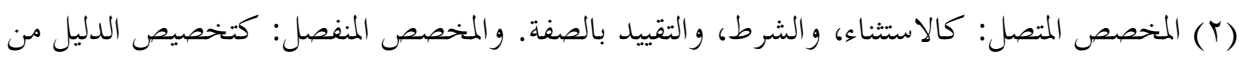

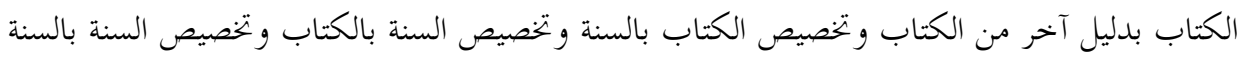

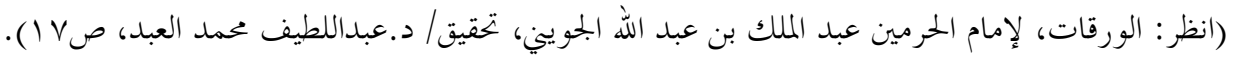


الضد، وإن تعددت أضداده يكون أمرا بو احد من أضداده، وثم مسائل أخرى يستكثر منها بعض المؤلفون وبعضهم يختصرها أو لا يذكرها؛ بناء على منهجه في كتابه (1). المسألة التاسعة: صيغة الأمر والنهي في الحديث

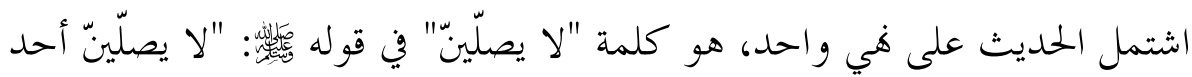
العصر إلّا في بني قريظة"، وبتطبيق القو اعد الأصولية أمكن استخر اج الدلالات التات التالية:

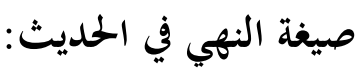
اشتمل الحلديث على صيغة واحدة من صيغ الأمر والنهي، هي: دخول لا الناهية على الفعل المضارع، وهذه الصيغة هي الصيغة الصريحة الدالة على النهي، ويقوم

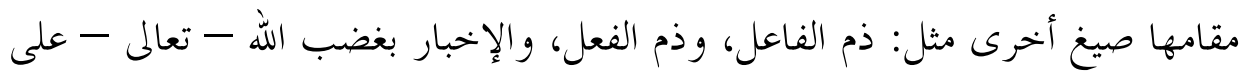
الفاعل، وترتيب العقوبة على الفعل. النهي في الحديث أمر بالضد: المنهي عنه في الحديث هو: الصلاة في غير بني قريظة، وهذا النهي له ضد واحد هو الصلاة في بني قريظة، فيكون أمرا بذلك الضد الوحيد. يقول ابن تيمية: "والأمر بالشيء هي عن ضده، و النهي عنه أمر بضده المعين إن لم يكن له إلا ضد و احد، وإلا فهو أمر بأحد أضداده"|(r) ويقول: "قولنا: (الأمر بالشيء هي عن ضده وأضداده، والنهي عنه أمر بضده أو بأحد أضداده) من جنس قولنا: (الأمر بالشيء أمر بلوازمه وما لا يتم الواجب إلا به فهو واجب، والنهي عن الشيء هي عما لا يتم اجتنابه إلا به)؛ فإن وجود المأمور به يستلزم وجود لوازمه و وانتفاء

(1) وقد نشرت بهوث متخصصة في الأمر والنهي، منها كتاب: د. حسن مرعي، وكتاب د.علي مصطفى رمضان، وكتاب د. دات الشثري.

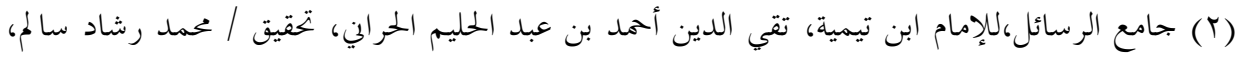

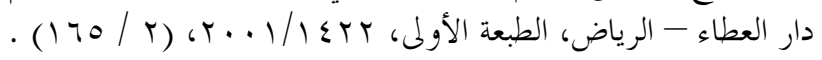


أضداده، بل وجود كل شيء هو كذلك يستلزم وجوده و انتفاء أضداده وعدم المنهي عنه" (1) (2)

ويقول ابن القيم: "الأمر بالشيء هى عن ضده من طريق اللزوم العقلي لا القصد

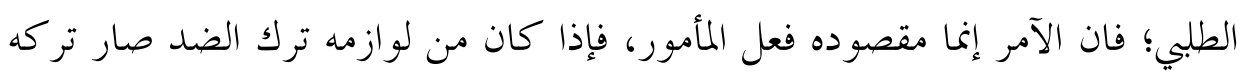

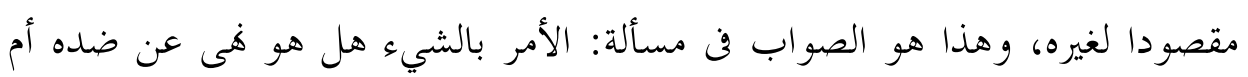
لا؟ فهو فى عنه من جهة اللزوم لا من جهة القصد والطلب، و كذلك النهي عن

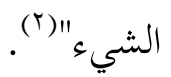

\section{الأمر بالأمر في الحمديث:}

إذا أمر شخص آخر بأن يأمر ثالثا بأمر، فهل يكون الأول آمرا للثالث؟ قاعدة

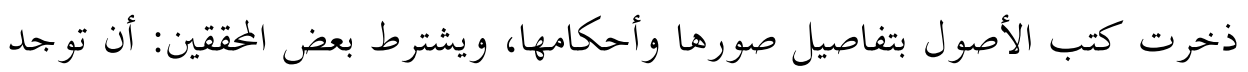

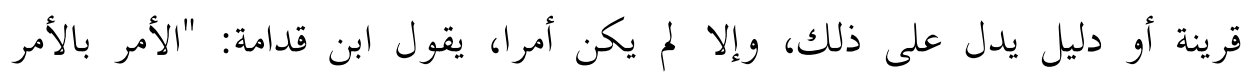
بالشيء ليس أمرا به ما لم يدل عليه دليل، مثاله قوله : بخطاب من الشارع للصبي ولا إيجابا عليه مع أن الأمر واجب على الولي"((؟) وقال بعض الأصوليين: إنه أمر ما لم تدل القرينة على العكس، يقول الإسنوي: "الأمر بالأمر بالشيء: كقوله لزيد: مر عمرا بأن يبيع هذه السلعة، هل يكون أمرا منه للثالث وهو عمرو - ببيعها؟ فيه خلاف، صحح ابن الحاجب وغيره أنه لا يكون أمرا

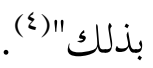

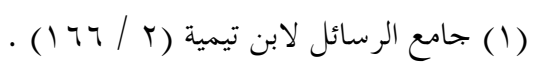

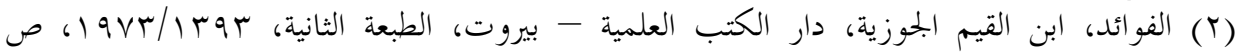

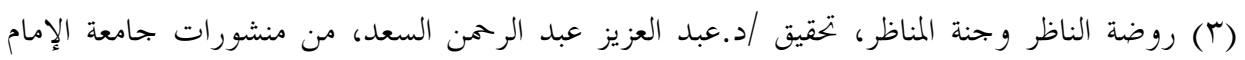

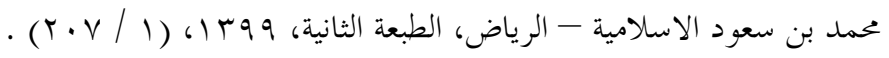

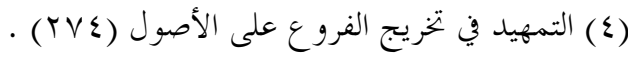


و يلاحظ: أن بعض الأصوليين(') يفرقون بين الأمر بالأمر كالمثال السابق، وهو محل الحلاف، و بين الأمر بتبليغ الأمر: كحديث "مره فليراجعها" فيجعلون هذا خارجا عن محل النــزاع، ومقتضاه أنه أمر بالاتفاق. وتطبيقا لهذه القاعدة أقول:

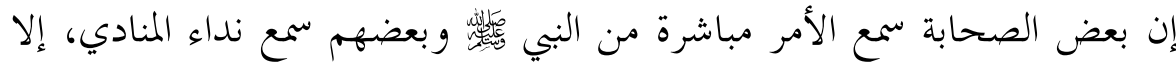

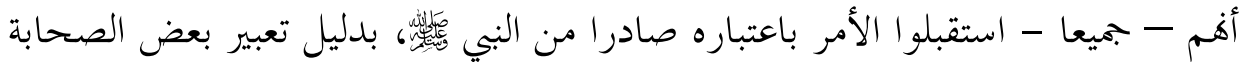

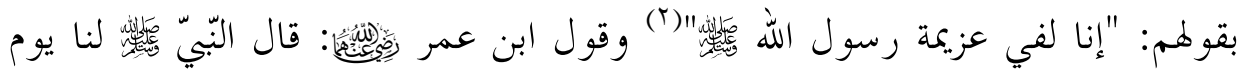

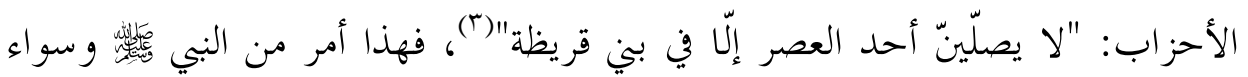
قلنا بأن المنادي بجرد مبلغ للأمر وليس آمرا، أم قلنا: إن هذا أمر بالأمر مع قيام الدليل

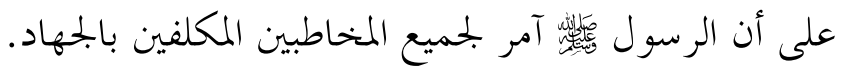
المسألة العاشرة: دلالات النهي في الحديث

\section{دلالة النهي في الحديث على التحريم:}

من المتبادر أن صيغة النهي في الحديث تدل على التحريم، والظاهر أن فريقي الصحابة - كليهما - فهم هذا الحكمم، وقد ذكرت ما يتعلق بالتحريم في موضعه، والذي يتعلق هـا هنا: أن النهي إذا بحرد عن القرائن الدالة على المقصود به يدل على التحريم عند الجمهور، وهذا النهي مما احتفت به القرائن الدالة على التحريم، فموضوعه كرئ

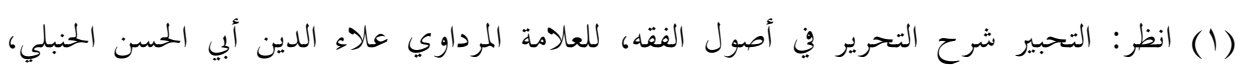

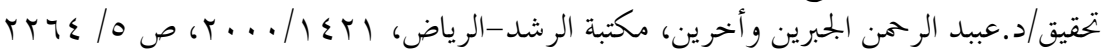

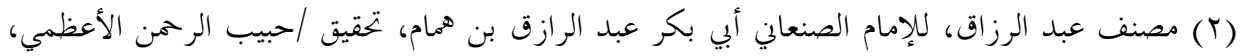

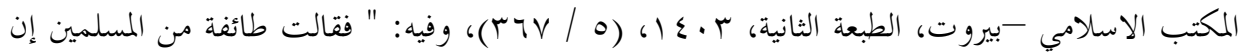

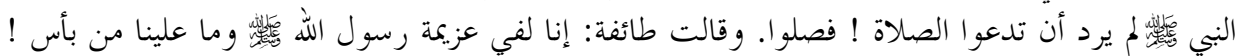

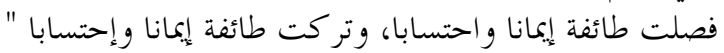

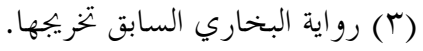


الجهاد، وهو من الواجبات الكفائية، ويتعين في النوازل، وإرسال المنادي يصدع بالنفير

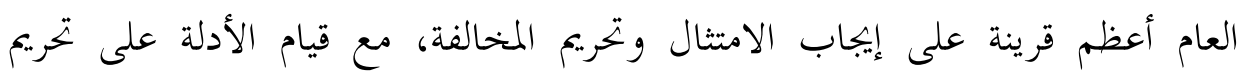

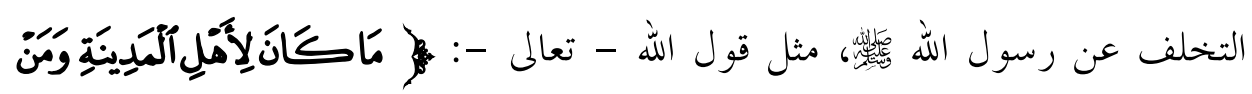

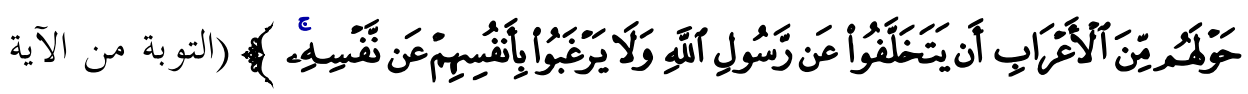
. (IT.

\section{النهي في الحديث لا يدل على الفساد:}

لا خحلاف بين الأصوليين في أن النهي يدل على فيدل فساد المنهي عنه إذا وقع، وذلك إنك

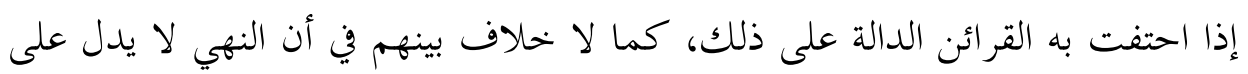

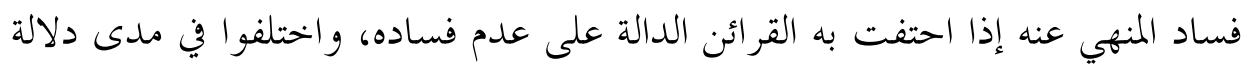
النهي الخرحد عن القرائن على الفساد (1).

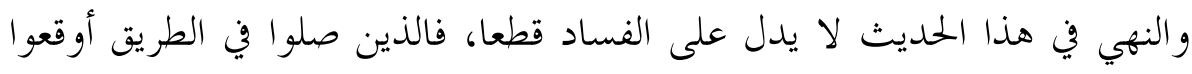

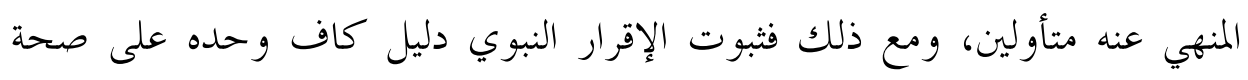
الصلاة، ناهيك عن كونه مشفوعا بعدم الأمر بإعادة الصلاة، فهذا يعبر عنه الأصوليون

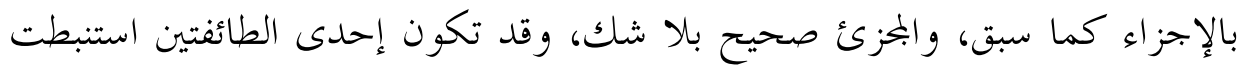

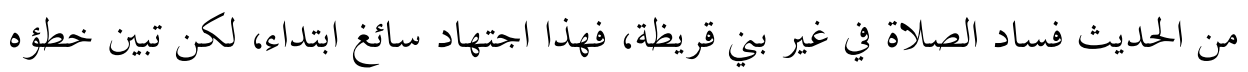
بإقرار الشرع خحلافه انتهاء. دلالة النهي في الحديث على الفور: التهاء

ومن المتبادر أيضا اقتضاء صيغة الطلب للفور، وقد فهم ذلك جميع المخاطبين،

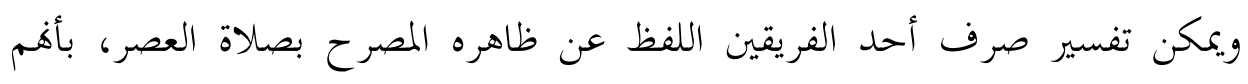

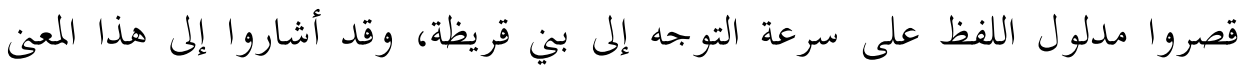


بقولم "لم يرد منا ذلك" يعني وإنما المقصود في الأصل هو الانطلاق على الفور، والنهي عن الصلاة في غيرها صورة من صور التعبير عن الفورية.

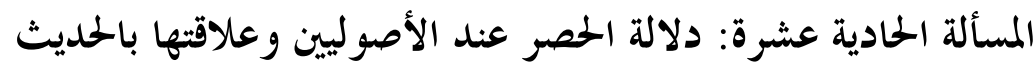

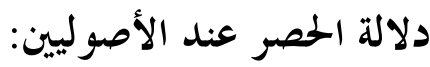

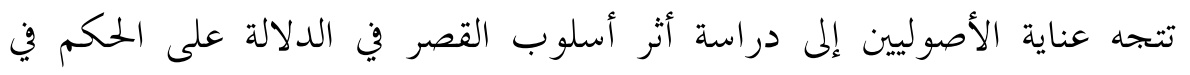

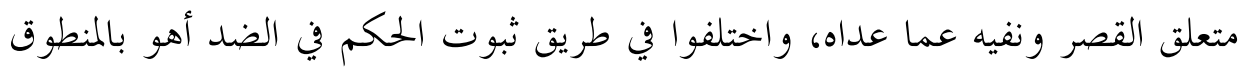

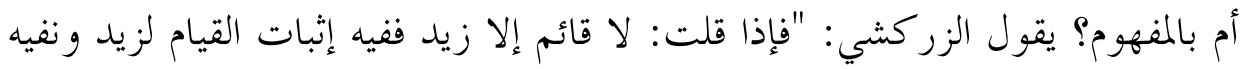

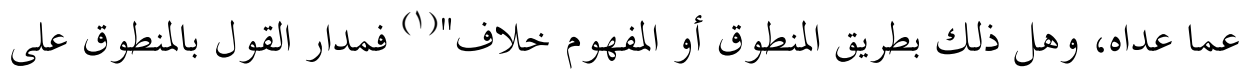

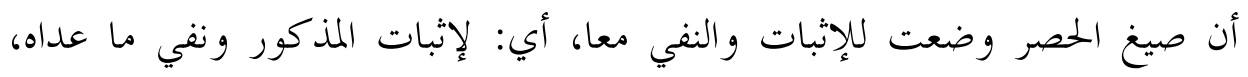

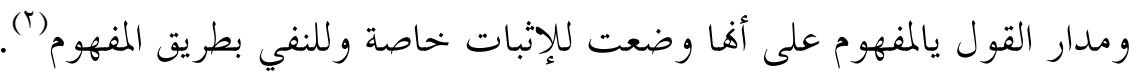

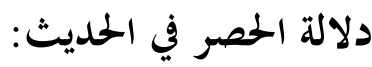

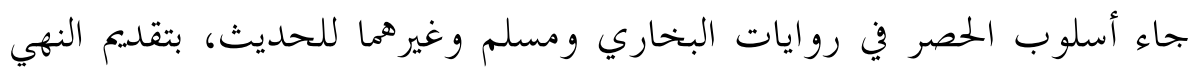

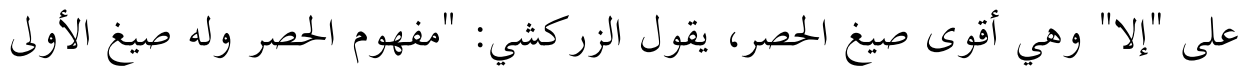

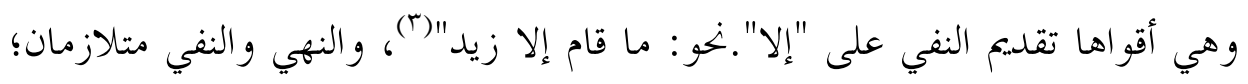

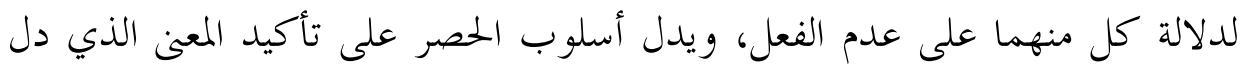

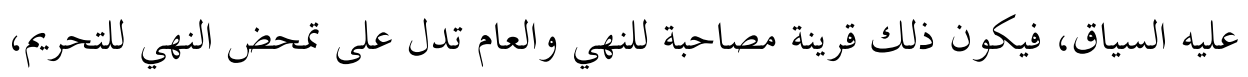
كما تدل على تمام استغراق العام وشموله لجميع أفراده.

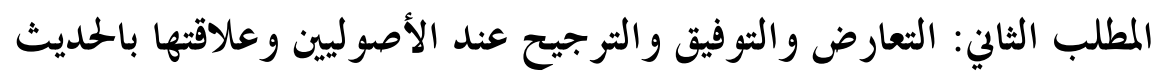

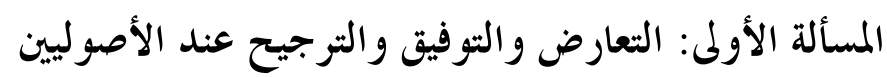

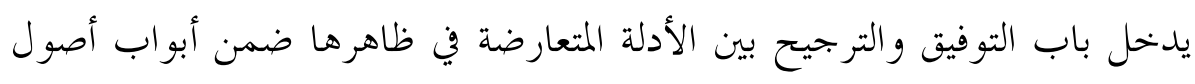

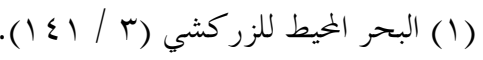

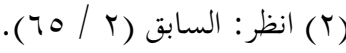

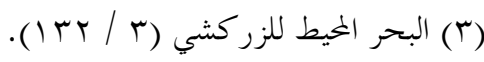


الفقه؛ لأنه من كيفيات استفادة الأحكام من الأدلة، ويقرر الأصوليون في هذا الباب: أن التعارض بين الأدلة الشرعية ليس حقيقيا له وجود في الواقع ونفس الأمر، و إنما هو

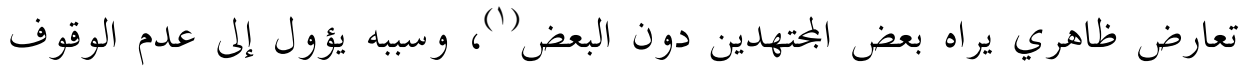
على الأدلة أو الدلالات، مع ثبوت التدرج في التشريع، ويقرر الأصوليون: أنه لا لا تسمع دعوى التعارض بين النصوص قطعية الثبوت قطعية الدلالة، وكذا الأخبار

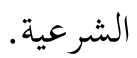

و يوجب جمهور الأصوليين على المجتهد أن يعمد إلى التوفيق بين الأدلة أولا، فيعمل

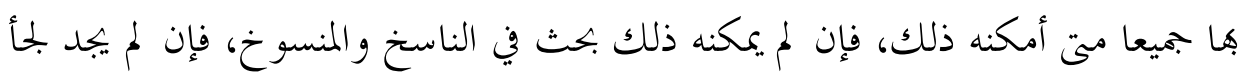

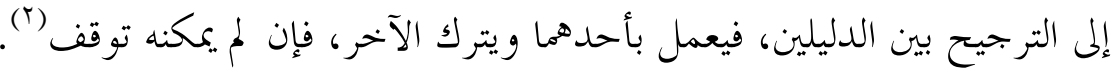

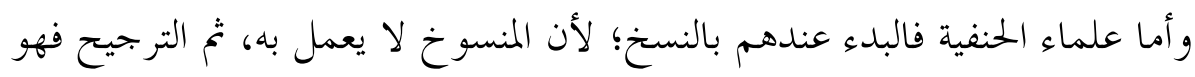
عندهم قبل الجمع؛ لأن الأصل العمل بكامل الدليل، ثم الجمع بين الأدلة، ثم التخيير

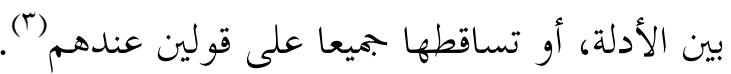

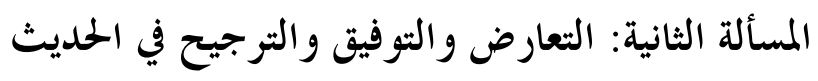
تعارض الأدلة في الحديث:

حين كاد وقت العصر أن ينتهي، و كان بعض المحاهدين لم يصلو إلى بني قريظة، تعارض في نظرهم دليلان: أولما: هذا الحديث الذي يوجب صلاة عصر ذلك اليوم في بني قريظة، مع تعذر إدراكها إلا بعد خروج الوقت، والثاني: عموم الأدلة على و جوب أداء كل صلاة في وقتها، وحرمة تأخيرها عن وقتها، إلا لعذر معتبر شرعا أو

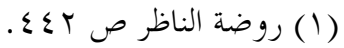

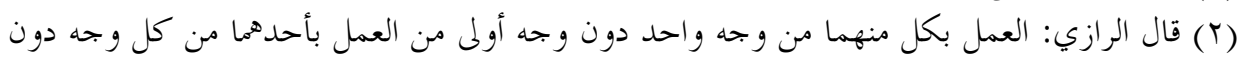

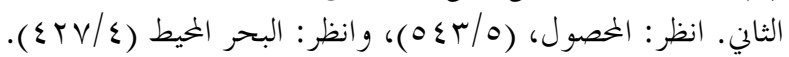

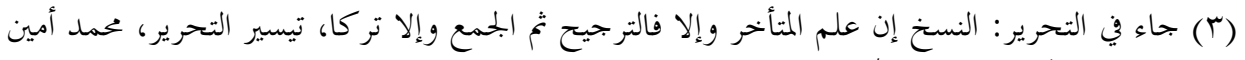

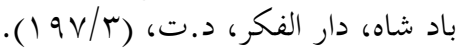


رخصة، ولا سيما صلاة العصر، فهي - على قول راجح - الصلاة الوسطى

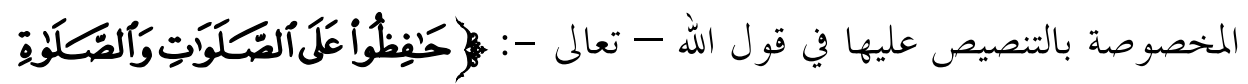

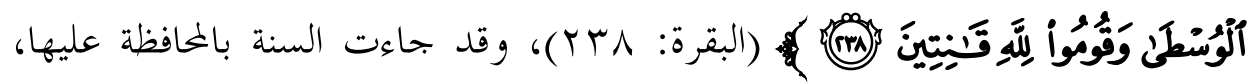

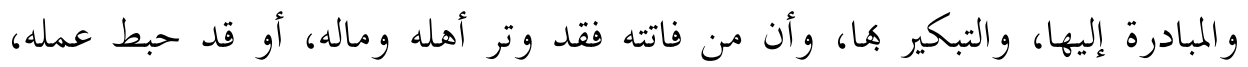
يقول العلامة النووي: "وأمّا اختلاف الصّحابة مِّيّة في المبادرة بالصّاة عند ضيق وقتها، و تأخيرها، فسببه أنّ أدلّة الشّرع تعارضت عندهم (1).

\section{الجمع بين الدليلين في الحمديث:}

اجتهل بعض علماء الصحابة في الجمع بين الدليلين، وذلك بالعمل بعموم الأدلة

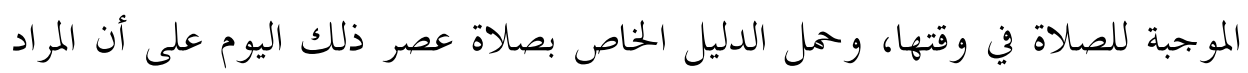
منه الإسراع، فعملوا به على هذا الوجه، فقد فهم الفريق الذي صلى قبل خروج

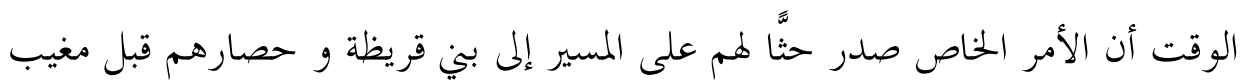
الشمس، وليس المقصود هو تأخيرها عن وقتها، فأعملوا نصوص الأمر بالصلاة على بلى فرئ و قتها على ظاهرها، و لم يهملو ا العمل بالنص الحاث، بل أسرعوا بالسير إلى بني قريظة عملا بمقصود الحديث، يقول العلامة ابن القيم: "الذين صلوا في الطريق جمعوا بين

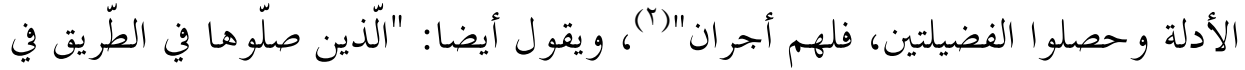
وقتها حازوا قصب السّبق و كانوا أسعد بالفضيلتين فإنّهم بادروا إلى امتثال أمره في

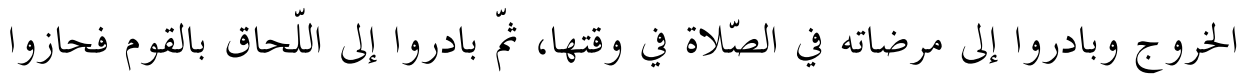
فضيلة الجهاد وفضيلة الصّلاة في وقتها، وفهموا ما يراد منهم وكانوا أفقه من

$$
\begin{aligned}
& \text { الآخرين" (ب) }
\end{aligned}
$$

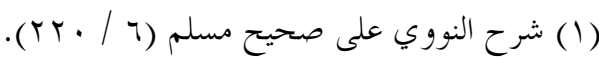

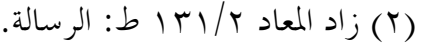

$$
\begin{aligned}
& \text { (T) نفس المرجع. }
\end{aligned}
$$


وأما كيفية الجمع فبتخصيص العموم، أو رد المتشابه إلى المكمم، ويقول الشيخ ابن عثيمين - رحمه الله -: "ولا ريب أن الصواب مع الذين صلوا الصلاة في وقتها؛ لأن النصوص في وجوب الصلاة في وقتها محكمة، وهذا نص مشتبه، وطريق العلم أن يحمل

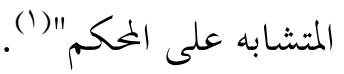

\section{ترجيح أحد الدليلين على الآخر عند تعذر الجمع:}

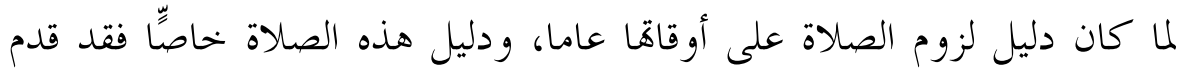
بعض المختهاين من الصحابة الخاص على العام، فعمدوا إلى إيقاع صلاة ذلك اليوم بخصوصه في المكان الذي اختصت به دون سائر الصلوات، فكان همهم صلاتها في بني قريظة امتثالا، دون التفات إلى الوقت الذي تصلى فيه صلاة العصر من كل يوم، ومن القواعد المقررة عند الأصوليين: أن الخاص يقضي على العام يقول التاج السبكي: "و الخاص يقضي على العام، ويقدم عليه عند التعارض" (؟).

و الصحابة الذين أخروا العصر عن وقتها وصلوها في بني قريظة قدموا دليلا خاصا

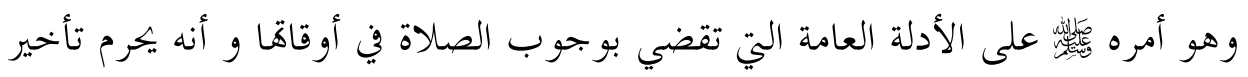

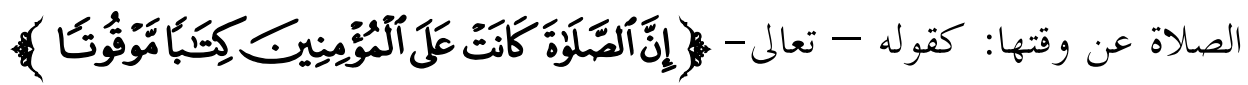

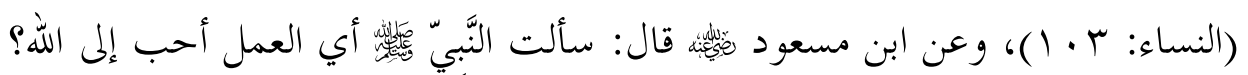
قال: "الصلاة على وقتها (r)".

***

$$
\text { (1) كتاب: العلم (r.r. (Y). }
$$

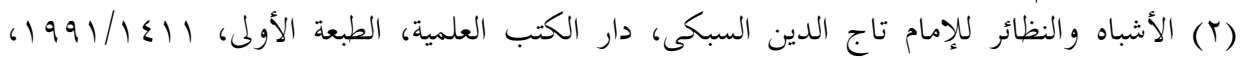

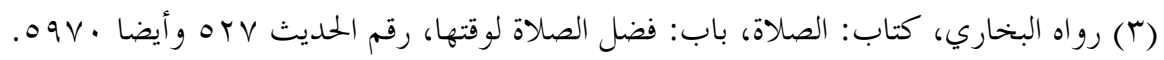




\section{الخاتمت}

الحمد لله أولا وآخرا، وظاهرا وباطنا، وصلى الله وسلم وبارك على نبيه وخير خلقه محمد وعلى آله وأصحابه أجمعين، وبعد: فأجمل في هذه الخاتمة للقارئ الكريم خلاصة البحث، ونتائجه، وتوصياته؛ سائلا

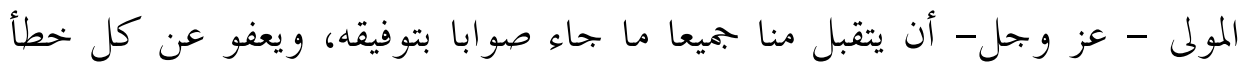
وزلل نعترف أنه من عند أنفسنا.

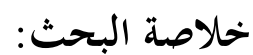

يوضح البحث: أن الاجتهاد مشروع في تأويل النص قطعي الثبوت عند البختهد،

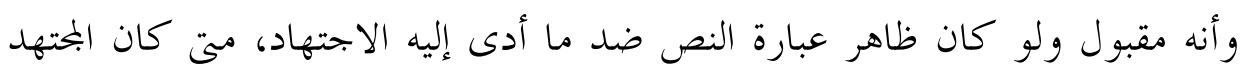

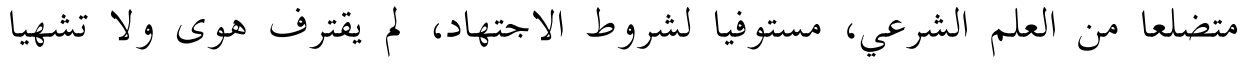

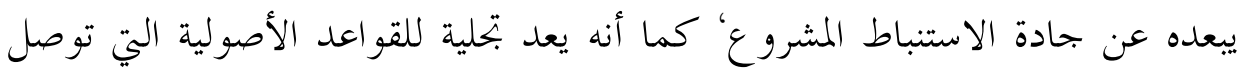

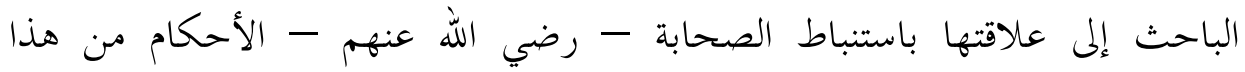

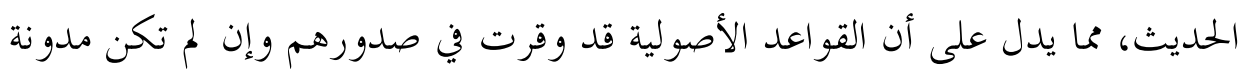

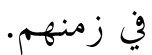

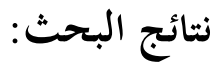

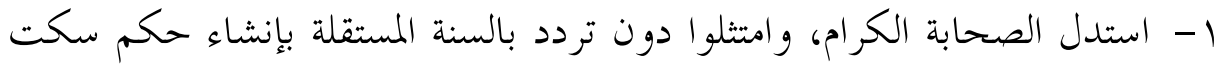

عنه القرآن، ولم ميجادلوا في حجيتها. r- السنة القولية قطعية الثبوت عند الصحابة الذين سمعوها مشافهة، لكن اجتهادهادهم واختلافهم في فهمها يدل على أفا ظنية الدلالة.

r- السنة التقريرية حجة قطعية عند الصحابة ومن جاء بعدهم، بدليل الاكتفاء بالسكوت النبوي دليلا على كل ما استبط من الحديث. 
ع - للقياس مدخلا في الاستباط من هذا الحديث، وذلك عبر فروع فقهية بعضها صحيح ومتعلق باجتهاد الصحابة، وبعضها قيل به وفيه نظر. ه- الطائفة الأولى ثبت لديها بالاجتهاد: أن الحلكم في هذا الموضع مبني على بلى المصلحة المرعية وهي حفظ الدين، ويتوصل إليها بالمسارعة لتحقيق عنصر المباغتة، واستدلت باستصحاب الأصل، وهو أداء كل صلاة في وقتها. 7- نظرا لورود النهي قطعي الثبوت واضح الدلالة، فمن المتبادر اتفاق الصحابة الكرام على حرمة القعود و التقاعس والتباطؤ عن الخروج إلى بني قريظة، ورأت إحدى الطائفتين حرمة صلاة العصر في غير بين قريظة، ويستلزم ذلك اتفاق الطائفتين على وجوب الخروج إلى بين قريظة، ووجوب الإسراع قصدا إلى هنالك، واختلفوا في بعض الفروع الفقهية الأخرى. - V الجهاد في أصله فرض كفاية، وقد تعين على المقصودين هذا الأمر النبوي، والإسراع في المسير إلى بني قريظة من مقدمة الواجب؛ لأن الامتثال بالأمر النبوي لا يتأتى عقلا إلا بالإسراع. 1- دخول وقت صلاة العصر ذلك اليوم سبب كاف لوجوبها على اجتهاد الطائفة الأولى، وعلى اجتهاد الطائفة الأخرى أصبح لها سبب مركب من أمرين: دخول وقتها، و الوصول إلى بني قريظة.

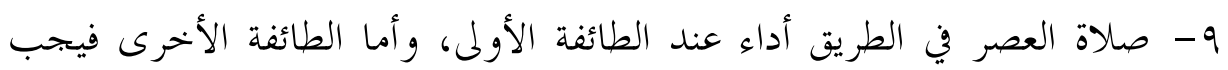
عليها أن تقول: هو تعجيل صححه الشرع للعذر، وصلاتها في بني قريظة أداء عند إحدى الطائفتين، وهي قضاء لم يرتب عليه الشرع إثما للعذر عند الطائفة الأخرى، وقد أجزأت كلا منهم صلاته، فلا يحتاج لإعادقا، كما ثبت بالتقرير النبوي، وعدم الأمر بإعادة الصلاة يستلزم الحلكم بالصحة على صلوات جميع أفر اد الطائفتين كلتيهما. 
• - - يمكن أن يخرج على اجتهاد الطائفة الأولى: أن صلاة العصر في بني قريظة

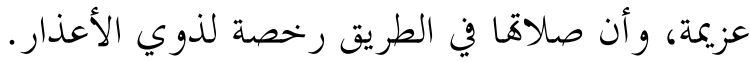

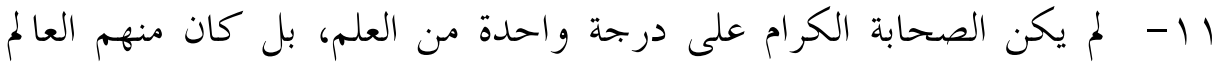
الذي بلغ رتبة المجتهد، ومنهم العامي المقلد، وقد اجتهد العلماء، وقلدهم سائر

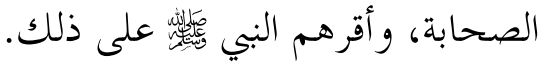
T ا - ذهب جمهور الأصوليين إلى القول بجواز اجتهاد الصحابة الغائبين عن بحلس البي لئي rا- لا يعنّف المحتهد فيما فعله باجتهاده إذا بذل و سعه في الاجتهاد، و إن كان

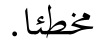

ع ا- المتهد يجب عليه العمل بما أداه إليه اجتهاده، وكذا المقلد يعمل بفتوى البحتهل، و لا يجب عليه الإعادة، وهذا الحلديث يشهد لهذه القاعدة. 10- الحديث شاهد لقاعدة " لا ينكر المختلف فيه ". 7 ا - الراجح: أن الخطاب النبوي في هذا الحديث من قبيل الظاهر، وقد تأولته لنه

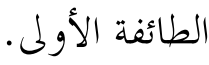
IV والتعبير بالمسبب وهو الصلاة في بي قريظة وإرادة السبب وهو الإسراع، ويجتمل الكناية.

11 - التكليف بالنفير عام يشمل جميع المكلفين الصادر إليهم الخطاب، و لا مانع من تخصيص العام بالأدلة.

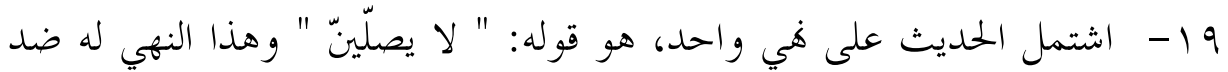

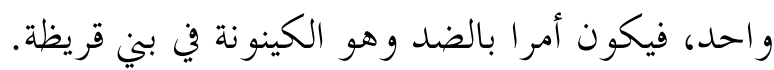

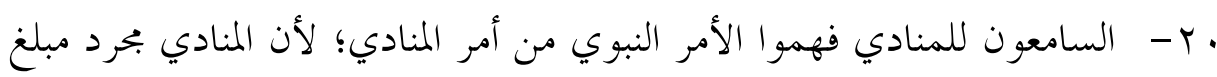
للأمر وليس آمرا. 
آ- صيغة النهي في هذا الحديث تدل على التحريم والفور، لكن لا تدل على الفساد قطعا.

r r أسلوب الحصر يدل على التشديد في الطلب. r T- بعض علماء الصحابة اجتهد فجمع بين الدليلين، وبعضهم اجتهد فرجح

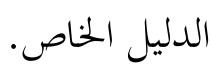

\section{توصيات البحث:}

وفي الختام أوصي من شرفهم الله - تعالى - بالتخصص في أصول الفقه أن يوجهوا أبناءهم، وطلاب علمهم، إلى البحث التطبيقي، وأن يكون الاهتمام الأكبر بالتطبيق

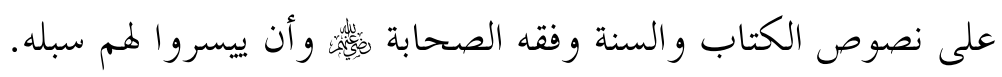

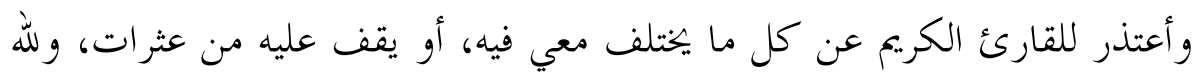
در العلامة الشاطبي، إذ يقول في حرز الأماني:

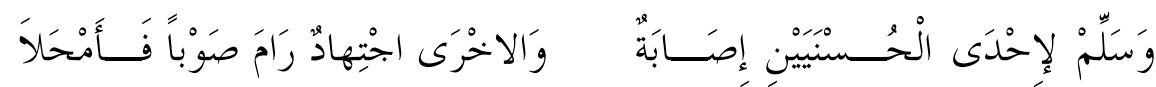

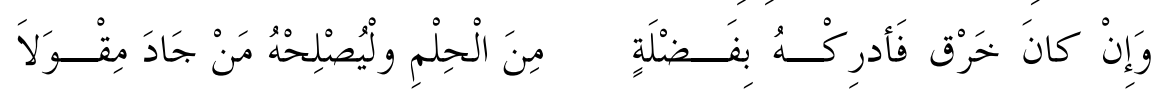

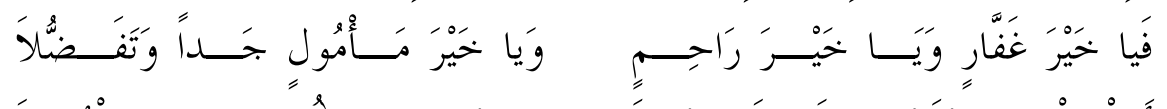

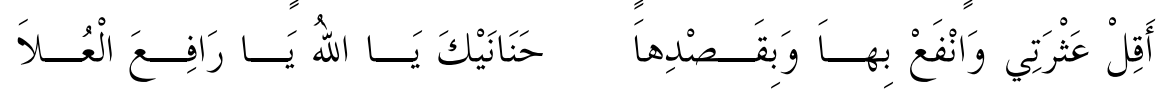

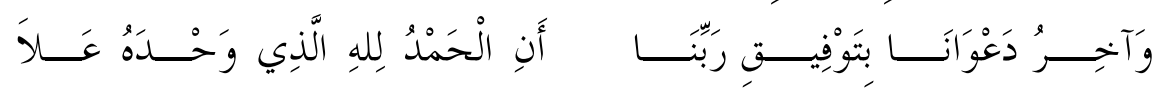

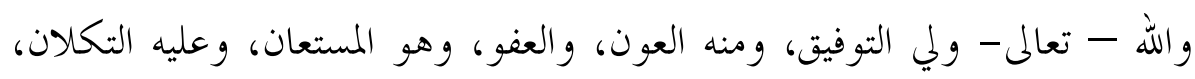

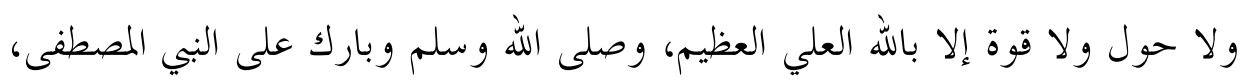

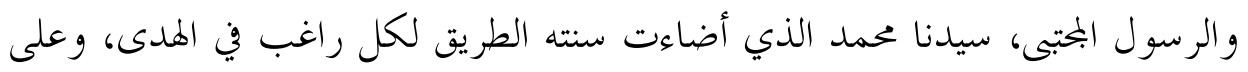
آله الطيبين، وصحبه الأكرمين، وخلفائه الراشدين، وسائر المتمسكين بسنته إلى يوم

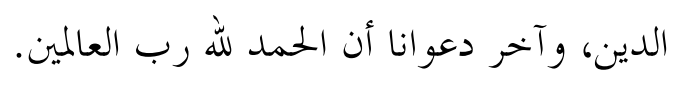




\section{ثبت المصادر والمراجع}

ا. الرسالة، للإمام الشافعي، محمد بن إدريس، المحقق: الشيخ أحمد محمد شاكر، دار الكتب العلمية.

r. الإبهاج في شرح المنهاج على منهاج الوصول إلى علم الأصول للبيضاوي، علي بن عبد الكافي السبكي، تحقيق/ جماعة من العلماء، دار الكتب العلمية بيروت، ع •ـ 1.

r. أثر الدرس اللغوى فى فهم النص الشرعى، محمد المختار محمد المهدي، من منشورات الجمعية الشرعية الرئيسية للعاملين بالكتاب والسنة المحمدية- مصر. ع. الاجتهاد المقاصدي حجيته، ضوابطه، مجالاته، للأستاذ الدكتور نور الدين بن غختار الخادمي، منشور ضمن سلسلة كتاب الأمة رقم بهرب، وزارة

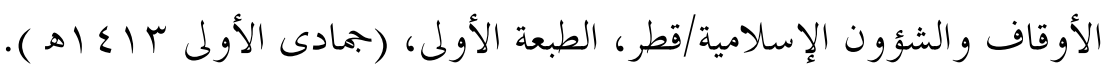

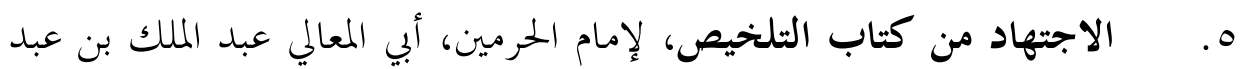
الله الجويني، تحقيق /د.عبد الحميد أبو زنيد، دار القلم - دمشق، الطبعة

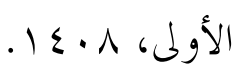
7. الأحاديث الضعيفة والموضوعة وأثرها السيء على الأمة، للشيخ الألباني،

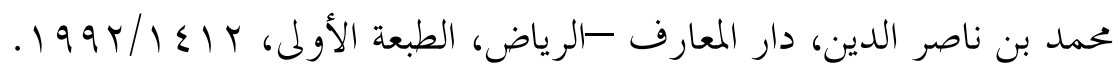
V. الإحكام في أصول الأحكام، لإمام ابن حزم، علي بن أحمد الأندلسي، دار

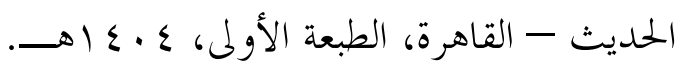

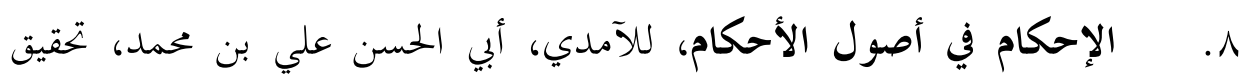
د.سيد الجميلي، دار الكتاب العربي - بيروت، الطبعة الأولى، ع • ع اهـــــئ. 
9. أدب المفتي والمستفتي، للإمام ابن الصلاح، أبو عمرو، تحقيق/د.موفق عبد الله

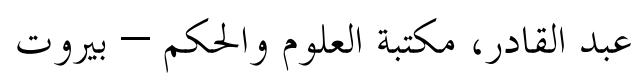

• 1 . الأدلة العقلية وعلاقتها بالنقلية عند الأصوليين، د. محمد سعيد شحاتة

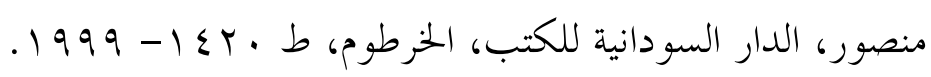

11 . إرشاد الفحول إلى تحقيق الحقى من علم الأصول، للإمام الشو كاني، محمد بن

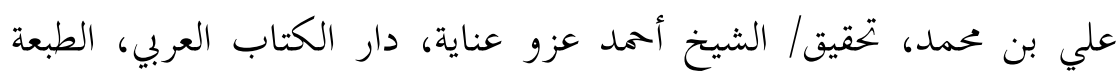

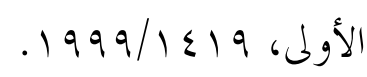

r ا. . الأشباه والنظائر للعلامة تاج الدين السبكى، دار الكتب العلمية، الطبعة

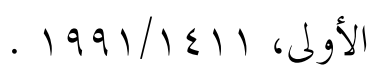

rا . أصول البزدوي - كتز الوصول إلى معرفة الأصول، للعلامة البزدوي، علي

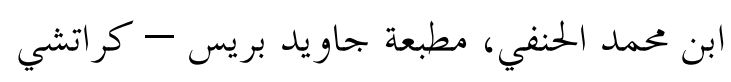

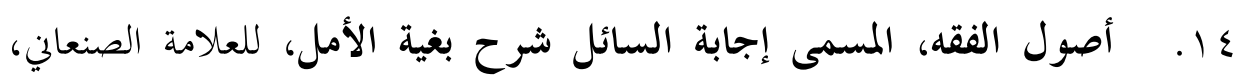

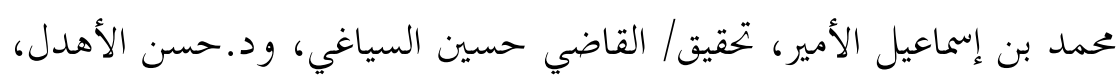
مؤسسة الرسالة -بيروت، الطبعة الأولى.

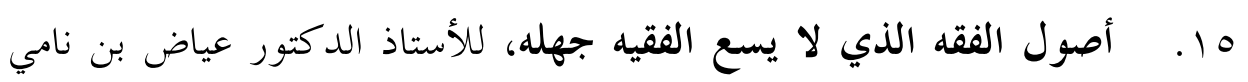

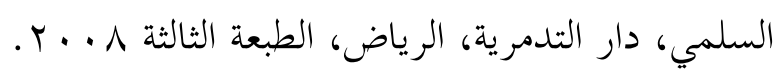

17 . أصول الفقه المسمى الفصول في الأصول، أحمد بن علي الرازي الجصاص، تحقيق / د.عجيل جاسم النشمي، نشر وزارة الأوقاف والشؤون الاسلامية -

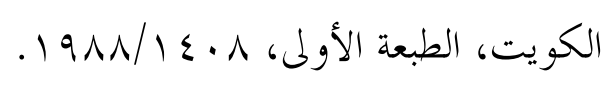

V ا . أصول الفقه على منهج أهل الحديث، لزكريا بن غلام قادر الباكستاني، دار 
11. الأصول من علم الأصول، للشيخ العلامة محمد بن صالح العثيمين -رحمه

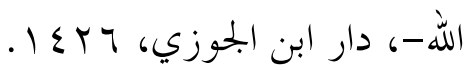

9 1. الأنجم الزاهرات على حل ألفاظ الورقات، للماردين، شمس الدين محمد بن عثمان الشافعي. •r. . . البحر الخيط في أصول الفقه، للعلامة بدر الدين الزركشي، محمد بن عبد الله

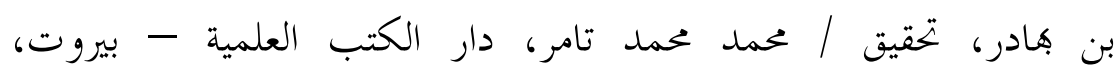
.

ا T. التحبير شرح التحرير في أصول الفقه، علاء الدين أبي الحسن المرداوي

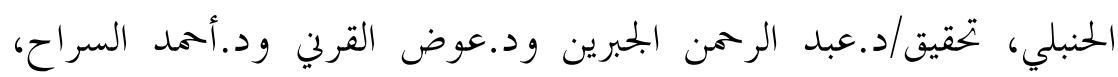

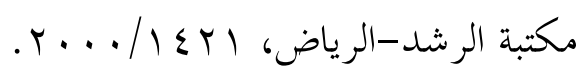
Y. . . تقريب التدمرية، للشيخ العلامة محمد بن صالح العثيمين - رحمه الله-، دار

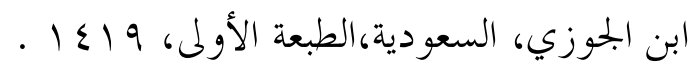
rr. . تلقيح الفهوم في تنقيح صيغ العموم، للحافظ العلائي، خليل بن كيكلدي،

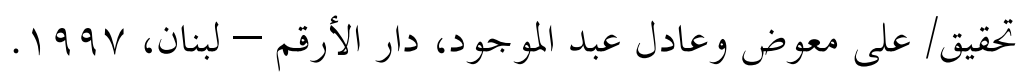
ع r. التمهيد في تخريج الفروع على الأصول، للعلامة الإسنوي، عبد الرحيم بن

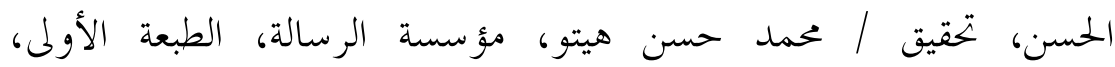
. $\rightarrow \leqslant .$. O. . تيسير التحرير، محمد أمين باد شاه، دار الفكر، د. ت. با . جامع الرسائل، للإمام ابن تيمية، تقي الدين أحمد بن عبد الحليم الحراين،

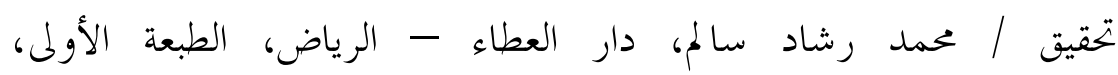
. r. . I/ $1 \leqslant r r$ 
rV . . الجحامع الصحيح، محمد بن إسماعيل البخاري، دار الشعب - القاهرة، الطبعة

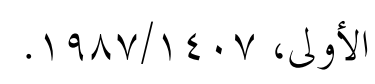

^r. . الجامع الصحيح، مسلم بن الحجاج النيسابوري، دار الجليل - بيروت . وجr. جامع بيان العلم وفضله، للإمام ابن عبد البر، أبي عمر يوسف بن عبد الله الله

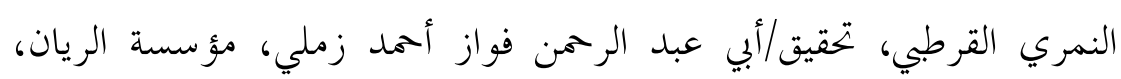

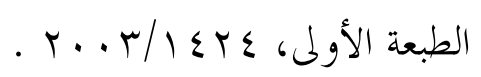

• r. حاشية العلامة البنالي على شرح الخلى على متن جع الجوامع لتاج الدين

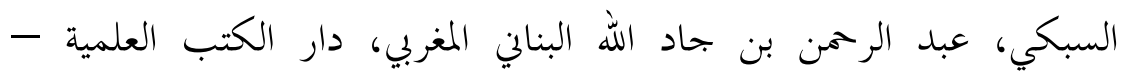

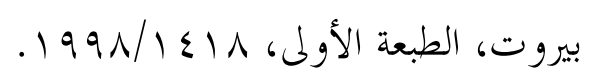

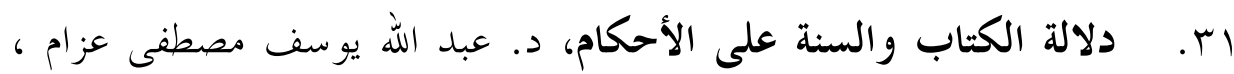

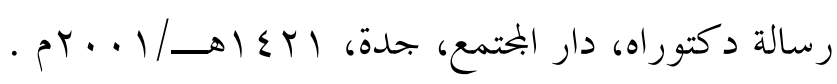
بr. دلائل النبوة، لإمام البيهقي، تحقيق/د.عبد المنعم قليجي، دار الكتب العلمية،

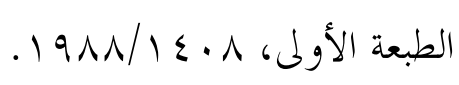

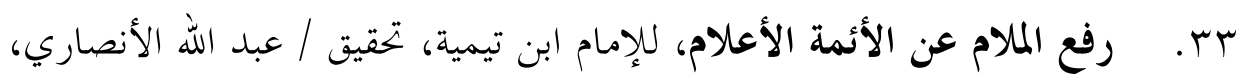
المكتبة العصرية - بيروت . ملاعم الأمه الاعلاف

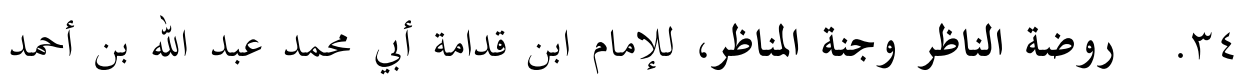

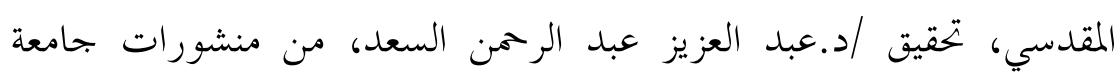

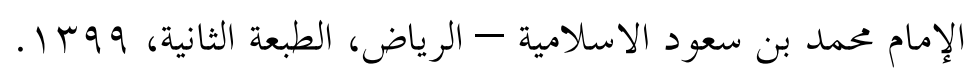

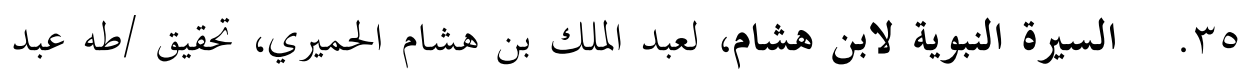

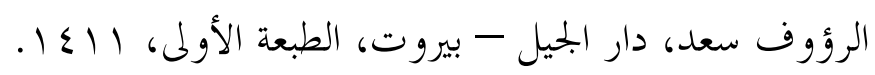

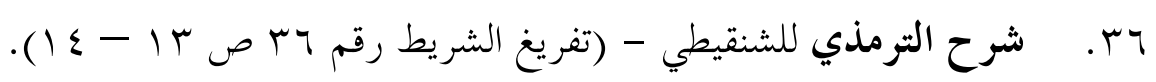


rV

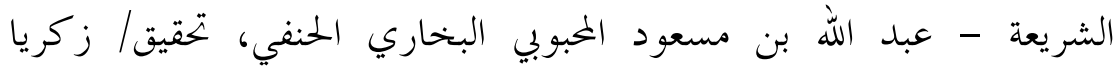

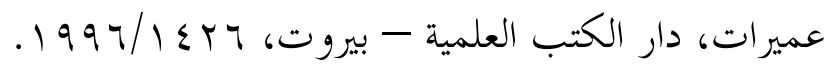

مץ. شرح الكوكب المنير شرح مختصر التحرير، للعلامة الفتوحي ابن النجار،

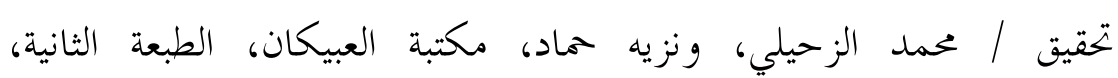
$.199 \mathrm{~V} / 1 \leq 11$

وبr. شرح جلال الدين الخلي على جمع الجوامع. • ـ . شرح صحيح البخارى، للحافظ ابن بطال، أبي الحسن علي بن بطال البكري

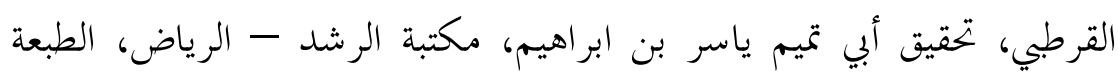

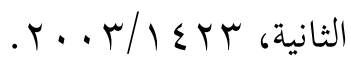

اءـ شرح مختصر الروضة، للعلامة الطوفي، بخم الدين سليمان الصرصري، تحقيق:

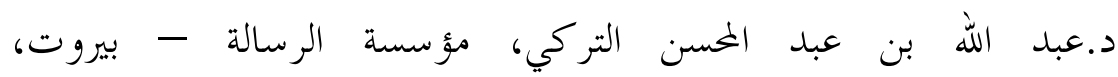
$.19 \wedge \mathrm{V} / 1 \varepsilon \cdot V$

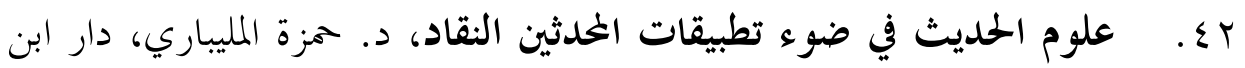
حزم، الطبعة الاولى. - مله

r؟ . فتح الباري، للحافظ ابن رجب، زين الدين عبد الرحمن البغدادي، تحقيق|

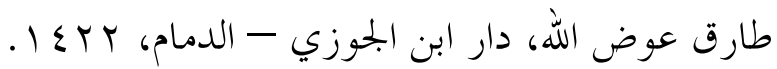
ع ـ الفقيه والمتفقه، للخطيب البغدادي، تحقيق / عادل عزازي، دار ابن الجوزي-

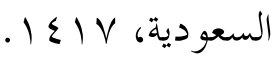
هـ . الفوائد، لإمام ابن القيم، عبد الرحمن بن أبي بكر الجوزية، دار الكتب العلمية

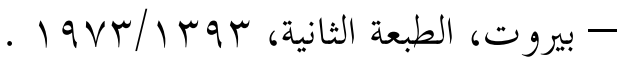


7ـ . فيض القدير شرح الجامع الصغير: لزين الدين المناوي، دار الكتب العلمية،

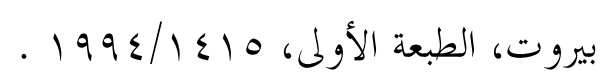

\& V . الخصول من علم الأصول، للعلامة الرازي، محمد بن عمر بن الحسين، تحقيق

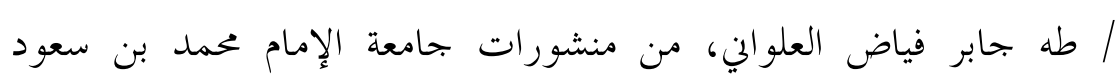

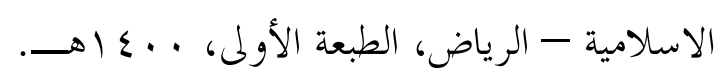

^ــ. مذكرة أصول الفقه على روضة الناظر للعلامة ابن قدامة، للشيخ العلامة

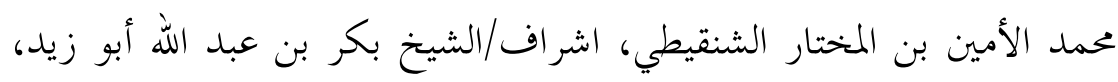
دار عالم الفوائد - مكة المكرمة، ومنشور ضمن مطبوعات بحمع الفقه لماته

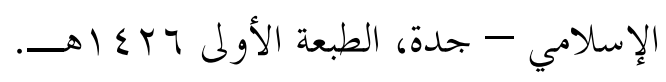

9؛ . المسودة في أصول الفقه، لآل تيمية، تحقيق / محمد ميى الدين عبد الحميد،

$$
\text { دار الكتاب العربي. }
$$

•.

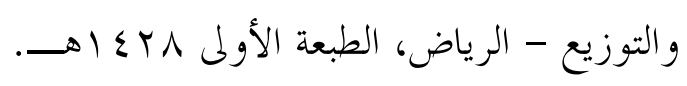

1ه. مصنف عبد الرزاق، أبو بكر عبد الرازق بن همام الصنعاني، تحقيق /حبيب

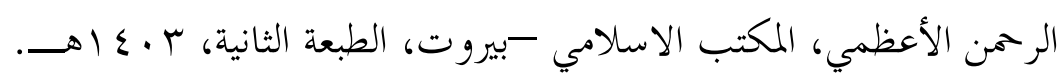

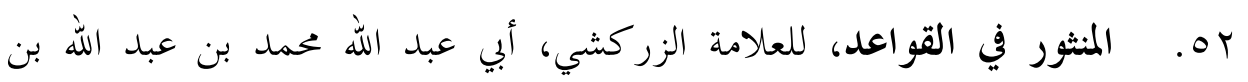

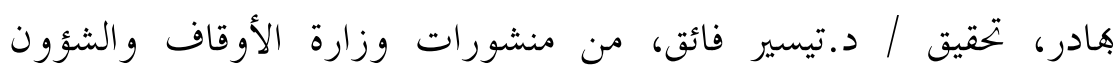

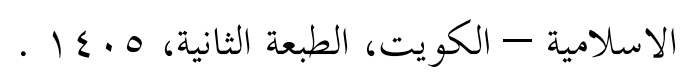

ro. المنهاج شرح صحيح مسلم بن الحجاج، للإمام النووي، أبو زكريا يهي

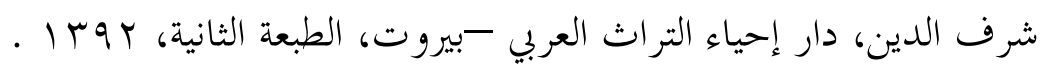
عه. الموافقات، للإمام الشاطب، ابراهيم بن موسى، تحقيق: أبي عبيدة مشهور 


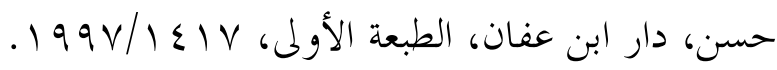

هـ. النص الكامل لكتاب العواصم من القواصم، للقاضي أبي بكر العربي، تحقيق

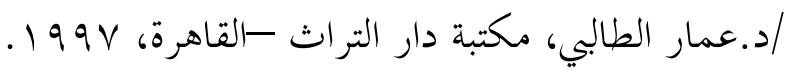

به. هاية السول شرح منهاج الوصول، للعلامة الإسنوي، جمال الدين عبد

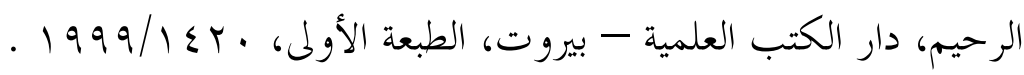

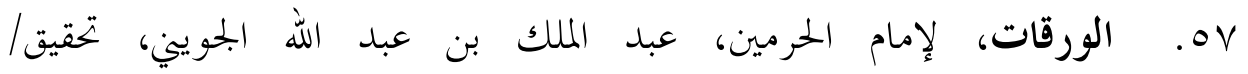

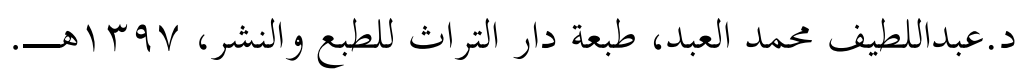

